\title{
ISOLAMENTO, SELEÇÃO E PRESERVAÇÃO DE FUNGOS PRODUTORES DE PECTINASES
}

\section{SONIA APARECIDA REIS LOPES-SHIKIDA Bióloga}

Orientador: Profa Dra ALINE A. PIZZIRANI-KLEINER

\begin{abstract}
Dissertação apresentada à Escola Superior de Agricultura "Luiz de Queiroz", da Universidade de São Paulo, para obtenção do título de Mestre em Agronomia, Área de Concentração: Microbiologia Agrícola
\end{abstract}

P IR A C I C A B A

Estado de São Paulo - Brasil

Janeiro - 1995 
CATALOERGAD MA FUELICAGAO

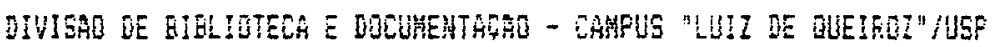

Lopes-Shikida. Suria Agareriga Rezs

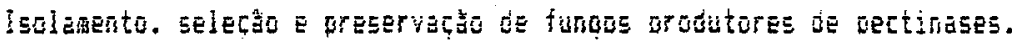

Piracicatas. 1795.

1220.

Disc. (Mestrei - EGALO

Eibiugaraiza.

1. Enzima pecholitica microtiana - Producto 2. Funa - IEolamento

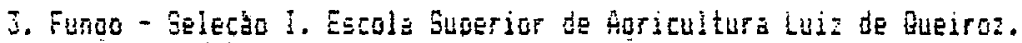
Firacicaia

CoD 576.11725 
ISOLAMENTO, SELEÇÃO E PRESERVAÇÃo DE FUNGOS PRODUTORES DE PECTINASES

SONIA APARECIDA REIS LOPES-SHIKIDA

Aprovada em 27/03/1995

Comissāo Julgadora:

Profa. Dra. Aline Aparecida Pizzirani-Kleiner

Prof. Dr. João Lúcio de Azevedo

Prof. Dr. Willibaldo Schimidell Neto
ESALQ / USP

ESALQ / USP

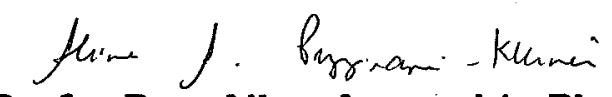

Profa. Dra. Aline Aparecida Pizzirani-Kleiner Orientadora 
- A yida é a arte de extrair conclusões suficientes de premissas insuficientes." 
Aos meus pais, Francisco J. Lopes

e Maria R. S. Lopes e a meu

irmão Odair R. Lopes (in memorian),

DEDICO

À minha familia e, em especial, ao meu marido, Pery F. Assis Shikida, pelo seu amor, dedicação e por tudo que representa em minha vida.

OFEREÇO 


\section{AGRADECIMENTOS}

. À DEUS e a OSHIEOYÁ-SAMÁ, pela oportünidade de participar de Sua Obra Criadora e por me ensinarem que a "Vida é Arte".

. À Profa. Dra. Marina Vairo, Maria Regina Campos Mello e ao Prof. Dr. Flávio Althertum, por terem propiciado o início desse caminho e pelo exemplo de confiança e respeito que aprendi a cultivar.

. À Profa. Dra. Aline A. Pizzirani-Kleiner, pelo apoio e orientação do presente trabalho.

. À Dra. Clarita S. Perez pela coordenação deste trabalho junto à FAPESP.

. À Margaretti S. Oliveira e ao Prof. Dr. Antonio Bonomi pelo apoio, incentivo e colaboração no que facilitou a realização deste trabalho.

- À Luiziana F. da Silva, pelo auxillio e pertinentes discussōes durante os relatórios da FAPESP e durante a etapa de preservaçăo das linhagens isoladas neste trabalho.

. À Valter Fontolam, pela disponibilidade e cooperação durante a preservaçăo das linhagens.

- À Fabiola Lorenzi e Marisa Seeder, que participaram diretamente na parte experimental do presente trabalho e que, através de suas dedicaçăo, colaboração e amizade, possibilitaram concluí-lo.

. Aos Professores Dr. Willibaldo Schimidell Neto e Dr. Alfredo E. Maiorano, pela colaboração e valiosas discussōes durante 0 andamento deste trabaho. 
- À Mônica Rosa Bertão, pela revisão dos originais e as valiosas discussões, pelo estímulo e convivência nos momentos difíceis, pelo companheirismo e afeto com que compartilhou da minha trajetória de vida.

- À Renata C. Pascon, pelo auxilio na reprodução fotográfica das pranchas e elaboração do Summary deste trabalho, pela convivência carinhosa, cuja presença amiga se fez marcante.

- Ao Prof. Dr. José S. Cunha Fernandes, pela confecção das análises estatísticas, apoio e compreensão sempre constantes.

. À todos os colegas do Departamento de Genética / ESALQ, em especial aos amigos João Pamphile, Marisa Vieira, Marcelo Vallim, Adriana Longo, Juliana Decico-Real, Salete Gaziola, pela oportunidade de um convivio enriquecedor.

- Aos docentes e funcionários ligados ao curso de Pós-graduação do Departamento de Microbiologia Agrícola e Departamento de Genética da ESALQ, em especial ao Prof. Dr. Luiz Gonzaga do Prado Filho e a bibliotecária "Bia", pelo apoio, compreensão e agradável convivio.

- Ao Instituto de Pesquisas Tecnológicas do Estado de São Paulo, em particular ao Agrupamento de Biotecnologia da Divisão de Química, onde foi desenvolvido este trabalho.

- Aos colegas do Agrupamento de Biotecnologia do IPT que colaboraram direta ou indiretamente na realização deste trabalho.

- À FAPESP, pelo apoio financeiro, no que possibilitou a realização do presente estudo.

. Ao CNPq, pela concessão da bolsa de estudos através do programa RHAE. 


\section{S U MÁRIO}

Página

LISTA DE TABELAS .

$x i$

LISTA DE FIGURAS

$x v$

LISTA DE ABREVIATURAS.

$x v$

RESUMO

xvi

SUMMARY

xviii

1. INTRODUÇÃO

2. REVISĀO DE LITERATURA

2.1. Substâncias pécticas (substrato)

2.2. Enzimas pectinolíticas.

2.3. Produção de enzimas pectinolíticas.................................................. 9

2.3.1. Fonte comercial de enzimas - aspectos gerais................................. 9

2.3.2. Enzimas pectinolíticas e sua origem ............................................. 10

2.3.3. Secreção de enzimas microbianas ................................................ 11

2.3.4. Metabolismo microbiano de poligalacturonatos - (pectina).............. 16

2.3.5. Controle da produção de enzimas microbianas - fatores que influenciam na produção............................................................................ 18

2.4. Importância e aplicação de enzimas pectinolíticas............................... 23

2.5. Isolamento e seleção de fungos produtores de enzimas pectinolíticas 25

2.6. Preservação das linhagens fúngicas produtores de enzimas pectinoliticas 27 


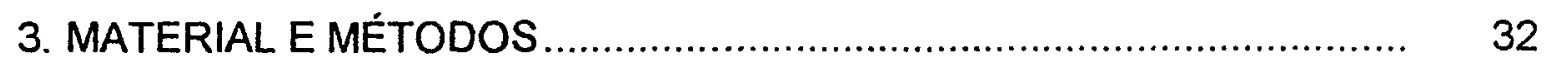

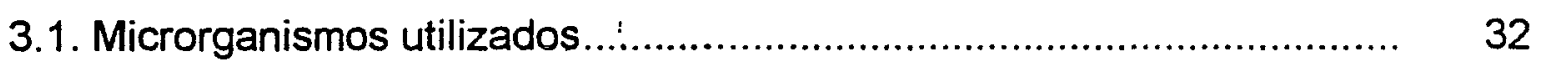

3.1.1. Isolados selvagens ............................................................ 32

3.1.2. Linhagens advindas de coleção de cultura ...................................... 32

- Aspergillus niger NRRL 337

- A. niger NRRL 3122

- A. niger ATCC-1025 (IZ-150)

- A. awamori AWG-547

- A. awamori NRRL-3112

- Aspergillus orysae

- Aspergillus tamanii

3.2. Manutenção das linhagens e obtenção de esporos.......................... 33

3.3. Esterilização e incubação ................................................................ 33

3.4. Meios de cultura e soluções utilizadas ............................................... 34

3.4.1. Meio Malt Extract Agar (Blakeslee's Form) - ATCC - 325 (ATCC Média handbook, 1984)................................................................ 34

3.4.2. Meio de Hankin (MH) - (Hankin \& Anagnostakis, 1975) ................. 34

3.4.3. Meio minimo (Pontecorvo et al., 1953) ......................................... 35

3.4.4. Meio completo (Pontecorvo et al., 1953, modificado por Azevedo \&

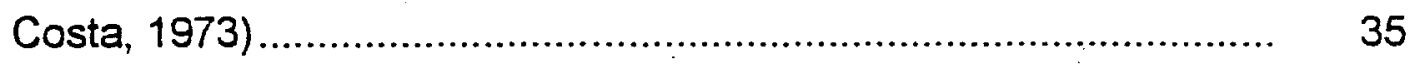

3.4.5. Solução de vitaminas ............................................................... 36

3.4.6. Solução tampāo de Mcllvaine (Mcllvaine, 1921)............................... 36

3.4.7. Solução tampão acetato (Maiorano, 1990) …................................... 36

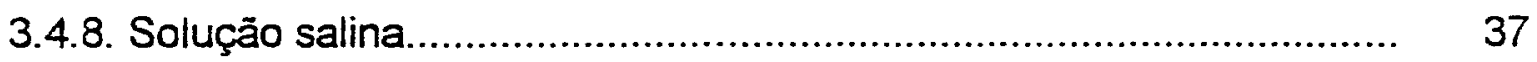

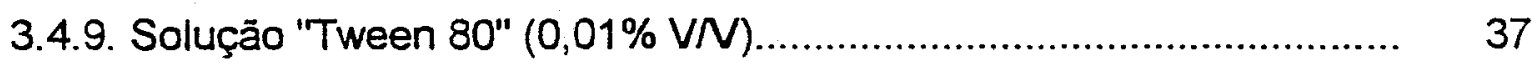

3.4.10. Solução de brometo de hexadeciltrimetilamônio $(-1 \%)$.................. 37

3.4.11. Solução de pectina ................................................................. 37

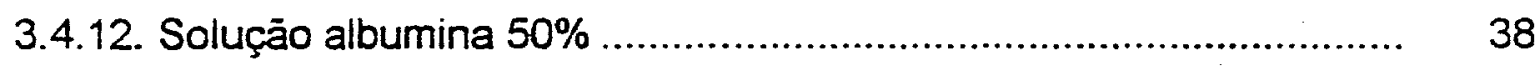

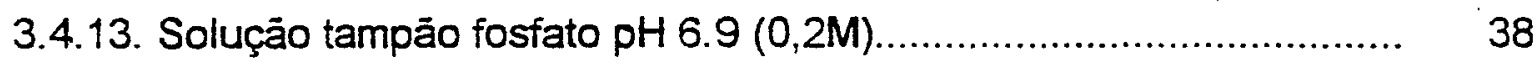

3.4.14. Solução de giemsa.............................................................. 38

3.4.15. Solução de desoxicolato de sódio $(10 \%$ p/v $)$.................................. 39 
3.5. Isolamento dos fungos pectinolíticos ................................................ 39

3.5.1. Isolados do solo ..................................................................... 39

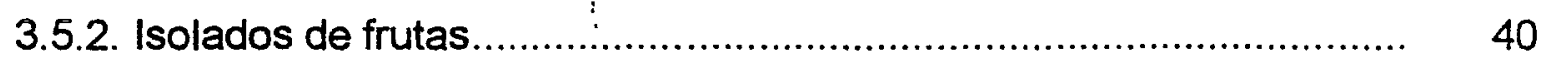

3.5.3. Nomenclatura utilizada para os isolados encontrados ................ 40

3.6. Seleção dos isolados em placas (meio sólido) .................................... 40

3.7. Seleção dos isolados ẹm cultura submersa......................................... 42

3.7.1. Produção de inóculo ................................................................. 42

3.7.2. Condições de fermentação ............................................................ 42

3.8. Cinética de crescimento e avaliação da atividade enzimática dos isolados

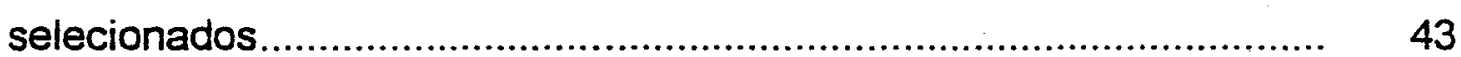

3.9. Acompanhamento analítico dos ensaios............................................ 43

3.9.1. Determinaçäo do crescimento micelial ......................................... 43

3.9.2. Avaliação da atividade enzimática..................................................

3.9.2.1. Método viscosimétrico.............................................................. 44

3.9.2.1.1. Procedimento ................................................................... 44

3.9.2.1.2. Cálculo da atividade enzimática ............................................ 45

3.10. Caracterização dos isolados selecionados...................................... 47

3.10.1. Classificação dos isolados..................................................... 47

3.10.2. Coloração de núcleos de conídios - Técnica citológica (Tanaka et al. 1979; modificado por Vega, 1990) .............................................. 47

3.10.2.1. Preparo da lâmina................................................................. 48

3.10.2.2. Determinação do número de núcleos por conídio ..................... 48

3.11. Preservação dos fungos pectinolíticos ........................................... 48

3.11.1. Preservação por liofilização .......................................................... 48

3.11.2. Preservação em nitrogênio líquido ............................................... 51

3.12. Sobrevivência à luz ultravioleta ...................................................... 51

3.12.1. Isolamento de mutantes morfológicos......................................... 52

3.12.2. Teste de reversão ................................................................. 52

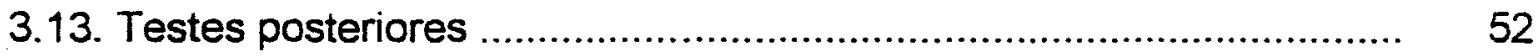


3.14. Análises estatísticas

4.2. Seleção dos isolados quanto a produção de enzimas pécticas especificas 55

4.2.1. Seleção em placas (meio sólido) .................................................. 56

4.2.2. Seleção em cultura submersa ........................................................... 68

4.3. Cinética de crescimento com avaliação da atividade enzimática das linhagens selecionadas

4.4. Caracterização das linhagens selecionadas..................................... 80

4.4.1. Classificação das linhagens........................................................ 80

4.4.2. Caracterização citológica das linhagens ........................................ 81

4.5. Determinação da redução de colônia pelo emprego de desoxicolato de sódio

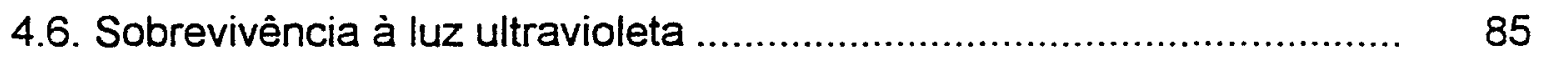

4.6.1. Obtenção de mutantes morfológicos................................................ 87

4.7. Seleçāo dos mutantes em cultura submersa ................................... 88

4.8. Cinética de crescimento com avaliação de atividade enzimática dos mutantes selecionados

4.9. Teste comparativo entre a cinética do mutante mais promissor e seu parental

4.10. Preservação das linhagens.

5. CONCLUSÕES 


\section{LISTA DE TABELAS}

1 - Classificação das enzimas pectinolíticas.

2 - Procedência dos isolados obtidos em diferentes coletas de solos e fontes naturais.

3 - Seleçăo dos isolados selvagens pelo método semiquantitativo (meio sólido), utilizando-se dois critérios de avaliação: Índice de Relação Enzimática (IRE) e Área de Degradação Enzimática (ADE). Os dados representam a média de 3 repetições, no tempo de 72 horas, as medidas em diâmetro $(\varnothing)$ são dadas $\mathrm{em} \mathrm{cm}$.

4 - Análise de variância do parâmetro indice de Relaçāo Enzimática (IRE) analisado em meio sólido e resultados do Teste de Tukey para as linhagens fúngicas avaliadas ( 3 repetiçōes).

5 - Análise de variância do parâmetro Área de Degradação Enzimática (ADE) analisado em meio sólido e resultados do Teste de Tukey para as linhagens fúngicas avaliadas ( 3 repetições).

6 - Seleção em cultura submersa das linhagens selvagens (medidas de atividade enzimática no tempo de 72 horas).

7 - Coeficiente de correlação simples entre pares de dados, utilizando as variáveis envolvidas na seleção em meio de cultura sólido $(A$ e $B)$ e em cultura submersa (C, D e E).

8 - Coeficiente de correlação simples entre pares de dados aplicados para os Indices: IC, IH e IUTMS e para parâmetros de avaliação na seleção em meio sólido $(A$ e $B$ ) e em meio liquido ( $C$ e $D)$. 
9 - Dados de cinética de crescimento com avaliação da atividade enzimática dos isolados selvagens selecionados. Os valores representam a média de três experimentos independentes e seu desvio padrão

10 - Análise de variância da massa celular seca (mg) obtida pelas linhagens selvagens selecionadas FP/21, FP/42, FFP/46, FP/69, FP/76, FP/83 e pela linhagem padrão $\mathrm{FP} / 107$, nos ensaios cinéticos realizados.

11 - Teste de Tukey para os valores médios da massa celular seca (mg) obtidos pelas linhagens selvagens selecionadas FP/21, FP/42, FP/46 FP/69, FP/76, FP/83 e pela linhagem padrão FP/107, nos ensaios cinéticos realizados.

12 - Análise de variância da Unidade enzimática total (Utotal) obtida pelas linhagens selvagens selecionadas FP/21, FP/42, FP/46, FP/69, FP/76, FP/83 e pela linhagem padrão FP/107, nos ensaios cinéticos realizado.. 79

13 - Teste de Tukey para os valores médios do parâmetro Utotal obtidos pelas linhagens selvagens selecionadas FP/21, FP/42, FP/46, FP/69, FP/76, FP/83 e pela linhagem padrão FP/107, nos ensaios cinéticos realizados.. 79

14 - Classificação taxonômica dos isolados selvagens selecionados

15 - Freqüência de núcleos por conídios das linhagens selvagens selecionadas.

16-Redução do diâmetro de colônias de Trichoderma harzianun Rifai, crescidas em meio completo (os dados constituem média de três repetições e estão expressos em $\mathrm{cm}$ ).

17 - Porcentagem de sobrevivência dos conidios de Trichoderma harzianum Rifai após exposição à luz ultravioleta (os dados constituem média de três repetições).

18 - Mutantes morfológicos, resultantes do tratamento de conidios da linhagem Trichoderma harzianum Rifai (FP/83), com luz ultravioleta, no tempo de exposiçäo de 4 minutos e 45 segundos. 
19 - Seleção em cultura submersa dos mutantes morfológicos provenientes da linhagem de Trichoderma harzianum Rifai FP/83 (medidas no tempo de 72 horas).

20 - Dados da cinética de crescimento com avaliação da atividade pectinolítica dos mutantes morfológicos selecionados, comparados ao parental FP/83. Os valores representam a média de três experimentos independentes e seu desvio padrão.

21 - Análise de variância da massa celular seca $(\mathrm{mg})$ obtida pelas linhagens mutantes selecionadas $1 / 4,1 / 9,2 / 3,6 / 1$ e pela linhagem parental FP/83, nos ensaios cinéticos realizados.

22 - Teste de Tukey para os valores médios da massa celular seca (mg) obtida pelas linhagens mutantes selecionadas $1 / 4,1 / 9,2 / 3,6 / 1$ e pela linhagem parental FP/83, nos ensaios cinéticos realizados.

23 - Análise de variância da Unidade enzimática total (Utotal) obtida pelas linhagens mutantes selecionadas $1 / 4,1 / 9,2 / 3,6 / 1$ e pela linhagem parental $\mathrm{FP} / 83$, nos ensaios cinéticos realizados.

24 - Teste de Tukey para os valores médios do parâmetro Utotal obtido pelas linhagens mutantes selecionadas $1 / 4,1 / 9,2 / 3,6 / 1$ e pela linhagem parental FP/83, nos ensaios cinéticos realizados.

25 - Análise de variância da massa celular seca (MS), obtida pelas linhagens selvagens selecionadas FP/83, FP/69 e pelos mutantes de FP/83: 1/4, 1/9, $2 / 3,6 / 1$, e linhagem padrão $F P / 107$, nos ensaios cinéticos realizados. 98

26 - Teste de Tukey para as médias de massa celular seca, obtido pelas linhagens selvagens selecionadas FP/83, FP/69 e pelos mutantes de FP/83: $1 / 4,1 / 9,2 / 3,6 / 1$, e linhagem padrão $F P / 107$, nos ensaios cinéticos realizados.

27 - Análise de variância da Unidade Enzimática Total (Utotal), obtida pelas linhagens selvagens selecionadas FP/83, FP/69, e pelos mutantes de 
FP/83: $1 / 4,1 / 9,2 / 3,6 / 1$, e linhagem padrão FP/107, nos ensaios cinéticos realizados.

28 - Teste de Tukey para as médias do parâmetro Utotal, obtido pelas linhagens selvagens selecionadas FP/83, FP/69, e pelos mutantes de FP/83: $1 / 4,1 / 9,2 / 3,6 / 1$, e linhagem padrão FP/107, nos ensaios cinéticos realizados.

29 - Análise de variância para o Índice clássico de Smith (IC), obtido pelas linhagens selvagens selecionadas FP/83, FP/69, e pelos mutantes de FP/83: $1 / 4,1 / 9,2 / 3,6 / 1$, e pela linhagem padrão $F P / 107$ nos ensaios cinéticos realizados.

100

30 - Teste de Tukey para médias do parâmetro de seleção (IC), obtido pelas linhagens selvagens selecionadas FP/83, FP/69, e pelos mutantes de FP/83: $1 / 4,1 / 9,2 / 3,6 / 1$, e pela linhagem padrão $F P / 107$ nos ensaios cinéticos realizados.

100

31 - Cinética comparativa da linhagem selvagem FP/83 e seu mutante 1/4 102

32 - Viabilidade de culturas fúngicas (Ufc/ml) submetidos à liofilização (os valores representam a média de três repetiçōes).

106

33 - Viabilidade de esporos fúngicos (Ufc/ml) submetidos à liofilização. Cada valor é média de três repetições.

106

34 - Viabilidade dos esporos das linhagens fúngicas isoladas neste trabalho e mantidas por criopreservação em nitrogênio líquido (Ufc/ml).

35 - Acompanhamento da produção de enzimas através da medida do IRE* das linhagens fúngicas liofilizadas.

36 - Acompanhamento da produção de enzimas através da medida do IRE* das linhagens fúngicas mantidas por criopreservação. 


\section{LISTA DE FIGURAS}

1 - Esquema da molécula de pectina e do modo de ação das enzimas pectinolíticas. ........................................................................... 6

2 - Secreção co-traducional de proteina bacteriana. ............................... 12

3 - A secreção e processamento de enzimas em eucariotos. ................... 13

4 - Representação diagramática de estruturas típicas de parede celular.... 15

5 - Via metabólica do ácido poligalacturônico em bactéria. ..................... 17

6 - Sintese enzimática como uma função do crescimento microbiano. .... 20

7 - Esquema para o processo de liofilização. ......................................... 50

8 - Cinética de crescimento com avaliação da atividade enzimática dos isolados selvagens selecionados. ................................................................ 77

9 - Linhagem FP/21 - conidios ovais uninucleados, normalmente em forma de correntes e núcleos bem acentuados (a); Linhagem FP/42 - conídios redondos de parede ornamentada, uni e binucleados (b), Linhagem FP/46 - conídios redondos, uni e binucleados (c); Linhagem FP/69 - conídios redondos irregulares, uni e binucleados (d). Aumento de 1.500x..... 82 10 - Linhagem FP 76 - conidios redondos, uni e binucleados (a); Linhagem FP/83 - conídios ovais uninucleados, núcleos acentuados (b); Linhagem FP/107 - conidios grandes multinuclear arredondados, de parede levemente ornamentada (c). Aumento de 1500x.

11 - Curva de sobrevivência dos conídios da linhagem de Trichoderma harzianum Rifai (FP/83) após exposição à luz ultravioleta. ................. 86

12 - Cinéticas de crescimento com avaliação da atividade enzimática dos mutantes morfológicos selecionados, comparadas ao parental (FP/83) e a linhagem padrão (FP/107).

13 - Cinética de crescimento com avaliação da atividade enzimática do mutante (1/4) e seu parental (FP/83).

\section{LISTA DE ABREVIATURAS}

UV - Ultravioleta

C/N - Relação Carbono/Nitrogênio

$U$ - Unidade enzimática

Utotal - Unidade enzimática total

Uesp - Unidade enzimática especifica 


\title{
ISOLAMENTO, SELEÇÃO E PRESERVAÇÃO DE FUNGOS PRODUTORES DE PECTINASES
}

\author{
Autora: Sonia A. Reis Lopes-Shikida \\ Orientador: Profa. Dra. Aline A. Pizzirani-Kleiner
}

\section{RESUMO}

O presente trabalho foi realizado como parte de uma linha de pesquisa desenvolvida no Agrupamento de Biotecnologia, Divisão de Química IPT, visando basicamente $O$ isolamento e seleção de linhagens fúngicas melhores produtoras de enzimas pectinolíticas, bem como a preservação adequada de tais linhagens.

O complexo enzimático em foco neste trabalho é composto por enzimas que degradam substâncias pécticas. As enzimas pectinolíticas são produzidas por vários microrganismos. Entretanto, para fins industriais, somente os de origem fúngica são utilizados. Tais enzimas têm sido largamente empregadas na indústria de processamento de frutas para maceração de polpas, extraçāo e clarificaçāo de sucos e vinhos.

Linhagens interessantes do ponto de vista industrial nem sempre säo encontradas a disposição em coleçōes de cultura, tornando-se premente o desenvolvimento de trabalhos que visem a busca de novos isolados com características satisfatórias para a produção do metabólito de interesse. Assim sendo, à também essencial que as linhagens promissoras encontradas sejam mantidas adequadamente para preservação de suas importantes características originais, justificando-se dessa forma o presente estudo.

Para obtenção de novos isolados da natureza, utilizou-se técnicas microbiológicas básicas de isolamento. $\mathrm{Na}$ seleção utilizou-se testes semiquantitativos (meio sólido) e quantitativos (meio liquido). Os testes aplicados refletiram em algumas distorções, que podem ser peculiares a cada 
método. Através destes, foi possivel selecionar a linhagem FP/83, posteriormente classificada como Trichoderma harzianum Rifai, que produz 2,5 vezes mais enzima que a linhagem padrão utilizada, FP/107 de Aspergillus orysae.

Mutantes morfológicos provenientes da linhagem FP/83 foram obtidos através da indução de seus conidios com luz ultravioleta. Para seleção dos mutantes encontrados utilizou-se apenas do teste quantitativo (meio de cultura líquido). Dentre estes, o mutante $1 / 4$ demonstrou sua superioridade quanto a produção de pectinases, sendo aproximadamente 2,5 vezes melhor que seu parental (FP/83) e cerca de 5,0 vezes a linhagem padrão (FP/107).

Os métodos de preservação, como liofilizaçāo e criopreservação em nitrogênio líquido, aplicados para as linhagens selecionadas demonstraram-se bastante adequados, refletindo-se na manutenção da viabilidade celular a niveis bastantes elevados para a maioria das linhagens. 


\title{
ISOLATION, SELECTION AND PRESERVATION OF PECTINOLYTIC FUNGI
}

\author{
Author: Sonia A. Reis Lopes-Shikida \\ Advisor: Profa. Dra. Aline A. Pizzirani-Kleiner
}

\section{SUMMARY}

The present work was conducted as part of research program developed at Biothecnology Department IQ/IPT, the aim was to isolate and select fungi strains best producer of pectinolytic enzymes, and the suitable way to preservate them. The pectinolytic complex studied in this work is composed of enzymes which are able to degrade pectinolict materials. These enzymes are produced by many microrganisms, but for industry proposab only fungi enzymes are employed. They are widely used on fruit processing industry, for pulp maceration, extraction and clarification of juice and wine. Interesting industrial strains are not always available in culture collections, so searching for new strains with suitable characteres for interesting metabolites production are necessary. In this way, it is essencial for the strains selected to be preserved, keeping original and important characteres, justifying the present work. New isolates from nature were obtained employing basic microbiologics techniques. To select them, tests such as quantitative (solid medium) and qualitative (liquid medium) were performed. They showed particular results. Theses tests were suitable to select the strain FP/83, that later was classified as Trichoderma harzianum Rifai which is able to produce 2,5 times more enzyme tham the standard strain, Aspergillus orysae, FP/107. Conidis of FP/83 were irradiated with U.V. light in order the get morfologics mutants which were selet employing quantitative test (liquid medium). The mutant $1 / 4$ was isolated showed a producing increase of 2,5 times more tham the parental strain and four folds than the standard strain FP/107 for 120 hours of fermentation. Concerning the preservation of these selected strains, liophylisation and criopreservation showed to be adequated. The maintenance of viability was verified to be high for almost all strains. 


\section{INTRODUÇÃO}

Os estudos de produção, bem como a utilização de enzimas por diferentes métodos tem se tornado um importante setor industrial na Biotecnologia. Tal setor tem apresentado taxas de crescimento bastante elevadas, variando de 10 a $17 \%$ ao ano entre 1980 e 1985, com volume de mercado mundial em torno de US $\$ 700$ milhões (MAIORANO, 1987).

Atualmente já foram identificadas e caracterizadas mais de 2.500 enzimas, das quais cerca de 300 são comercializadas em pequenas quantidades e cerca de 50 têm sido obtidas em quantidades suficientes para uso em escala industrial. Nesse contexto, as hidrolases têm apresentado uma posição de destaque em relação às demais enzimas (GODFREY, 1986). Dentre estas as pectinases foram escolhidas como objeto de estudo no presente trabalho.

As enzimas pectinolíticas são produzidas por plantas e microrganismos, principalmente bactérias e fungos filamentosos, e alguns protozoários e leveduras. O complexo pectinolítico é composto por enzimas que degradam substâncias pécticas. Tais enzimas são largamente usadas na indústria de processamento de frutas para maceraçāo de polpas, extração e clarificação de sucos e de vinhos, sendo usada para esta finalidade somente as enzimas de origem fúngica. A clarificação de sucos é um dos maiores campos de aplicação das pectinases, principalmente para sucos de maçã, uva e pêra (SIÉSSERE, 1991).

Apesar do grande progresso alcançado a nivel mundial, a enzimologia no Brasil ainda apresenta um desenvolvimento insuficiente. Embora exista no pais uma pequena capacitação tecnológica para a produção de algumas hidrolases, pouco se investe em áreas fundamentais para tal desenvolvimento, tais como manutenção de bancos de microrganismos 
produtores de enzimas, processos de recuperação, purificação e concentração de enzimas, e procedimentos para ampliação de escala (MAIORANO, 1991).

A produção de 'enzimas microbianas está fundamentalmente ligada a três etapas: seleção do microrganismo, processo de fermentação e recuperaçāo do produto. O desenvolvimento do processo de produção em escala industrial de uma enzima, com qualidade satisfatória e a custos que permitam sua comercialização, não é muito simples de ser alcançado. Para tal, é necessário que se encóntre uma combinação ótima entre a linhagem de microrganismo, meio de cultura, processo de fermentação e os métodos de recuperação do produto (BARFORD, 1981).

Desta forma, pelas razões apontadas, justifica-se o trabalho que vem sendo realizado no Agrupamento de Biotecnologia da Divisảo de Química do Instituto de Pesquisas Tecnológicas do Estado de São Paulo S.A. - IPT, visando 0 desenvolvimento de processos de produção de enzimas pectinoliticas a nivel industrial e a conseqüente capacitação de pessoal para a área de enzimologia.

As constatações acima relacionadas indicaram a importância da realização do presente trabalho que objetivaram principalmente:

a) Isolamento de fungos de fontes naturais, produtores de pectinases;

b) Seleção de linhagens produtoras de pectinases;

c) Identificação das linhagens selecionadas;

d) Preservaçāo das linhagens produtoras de pectinases. 


\section{REVISÃO DE LITERATURA}

\subsection{Substâncias péċticas (substrato)}

Os polissacarideos celulose, hemicelulose e pectina, são os 3 principais componentes da parede celular de plantas (GOODENOUGH, 1991). As substâncias pécticas são encontradas, principalmente, na lamela mediana e parede celular primária de muitas plantas superiores. Estão presentes em quantidades geralmente não excedentes a $1 \%$ da massa da planta, em peso fresco (Doesburg, 1965 \& Kawabata, 1977 citados por ROMBOUTS \& PILNIK, 1980), sendo responsáveis pela integridade e aderência dos tecidos da planta, ou seja, apresentam grande influência tanto na consistência, como no aparecimento e estabilização de turvação em sucos de frutas e vegetais. Assim sendo, a textura das plantas e vegetais é muito influenciada pela quantidade e natureza das substâncias pécticas presentes. A maioria dessas substâncias em frutos verdes está na forma de protopectina, a qual é transformada em pectina solúvel durante a maturação (FOGART \& KELLY,1983).

Estas substâncias, em sua forma natural são heteropolissacarídeos de peso molecular entre 30.000 a 300.000 , consistindo de uma cadeia principal formada por unidades do ácido $\alpha$-D-galacturônico com ligações de $\alpha-1,4$.

Numa designação mais genérica, as substâncias pécticas foram denominadas como derivados coloidais de carboidratos, porque o ácido galacturônico em vegetais é derivado da galactose via oxidação do grupo alcoólico do carbono 6 . Há grande proporção de unidades de ácido anidro galacturônico, formando uma cadeia polimérica.

Os grupos carboxila do ácido poligalacturônico podem ser encontrados parcialmente esterificados com grupos metil ou completamente neutralizados por uma ou mais bases. O grau de esterificação varia com a 
procedência da pectina. Pequenas quantidades de resíduos de L-ramopiranose estão ligadas no C-1 e C-2 da cadeia principal. Algumas hidroxilas do C-2 ou C-3 podem estar acetiladas, existindo valores de acetilação que variam de $0,2 \%$ no caso da pectina cítrica e de maçã, e de 2 a $4 \%$ em pectina do bagaço de beterraba. Cadeias laterais de açúcares neutros, principalmente galactose, arabinose e xilose, encontram-se covalentemente ligadas ao C-2 e C-3 da unidade monomérica (Fogarty \& Ward, 1974, Rombouts \& Piinik, 1980, Fogarty \& Kelly, 1983, apud MAIORAंNO, 1990 e SIESSÉRE, 1991).

Em meados da década de 40 , em vista das controvérsias existentes a respeito da nomenclatura das substâncias pécticas, um comitê da "American Chemical Society" apresentou várias definiçōes para estas complexas substâncias, recebendo a seguinte classificação:

- Protopectina - é a substância original do grupo de substâncias pécticas que ocorrem em plantas; é insolúvel em água e sob hidrólise parcial produz ácidos pectínicos;

Ácidos pectínicos - são ácidos poligalacturônicos coloidais, contendo uma pequena proporção de grupos metil ésteres. Estes ácidos em condições apropriadas são capazes de formar géis com açúcares e ácido;

- Pectinas - são os ácidos pectínicos solúveis em água, de cujo conteúdo de metil ésteres e grau de neutralizaçāo são variáveis. Também são capazes de formar géis com açúcares e ácidos, sob condiçōes adequadas.

. Ácido péctico - nome dado a substâncias pécticas compostas, principalmente de ácidos poligacturônicos coloidais e essenciaimente livres de metoxilação. Os sais de ácidos pécticos são pectatos neutros ou ácidos. 


\subsection{Enzimas pectinolíticas}

As enzimas, cataliśadores de reações biológicas, representam um importante papel no setor da indústria de alimentos. As enzimas pectinolíticas, devido a sua capacidade de atuar na degradação de polissacarídeos pécticos, constituem-se num grupo de enzimas de relevante importância, apresentando diferentes mecanismos de ação.

A degradaçãó completa da parede celular de vegetais, normalmente é realizada por uma grande variedade de enzimas nas quais as pectinases estão incluidas (GOODENOUGH, 1991).

O termo pectinase é freqüentemente aplicado para misturas brutas de enzimas pectinolíticas. Estas são classificadas segundo seu modo de açăo na estrutura poligalacturônica (Figura 1) da molécula da substância péctica. De acordo com o modo de ação dessas enzimas, elas foram classificadas em dois tipos distintos: enzimas desesterificantes e despolimerizantes (PARK \& PAPINI, 1968, ROMBOUTS \& PILNIK, 1980, FOGART \& KELLY 1983). Ao primeiro grupo pertencem as pectinesterases (PE), as quais catalisam a remoçāo dos grupos metilicos da molécula de pectina, produzindo álcool metilico e ácidos pectínicos até pécticos, expondo os grupamentos carboxilicos à ação de catiôns multivalentes como o cálcio. Essa ação dá origem a sais insolúveis, que facilmente podem ser removidos (PARK \& PAPINI, 1968 e ROMBOUTS \& PILNIK, 1980).

As enzimas do tipo despolimerizantes catalisam a quebra das ligacões $\alpha-1,4$ da cadeia principal do polissacarídeo péctico, ou seja, quebram as ligaçöes glicosidicas por hidrólise (hidrolases) ou por B-eliminação (liases). 

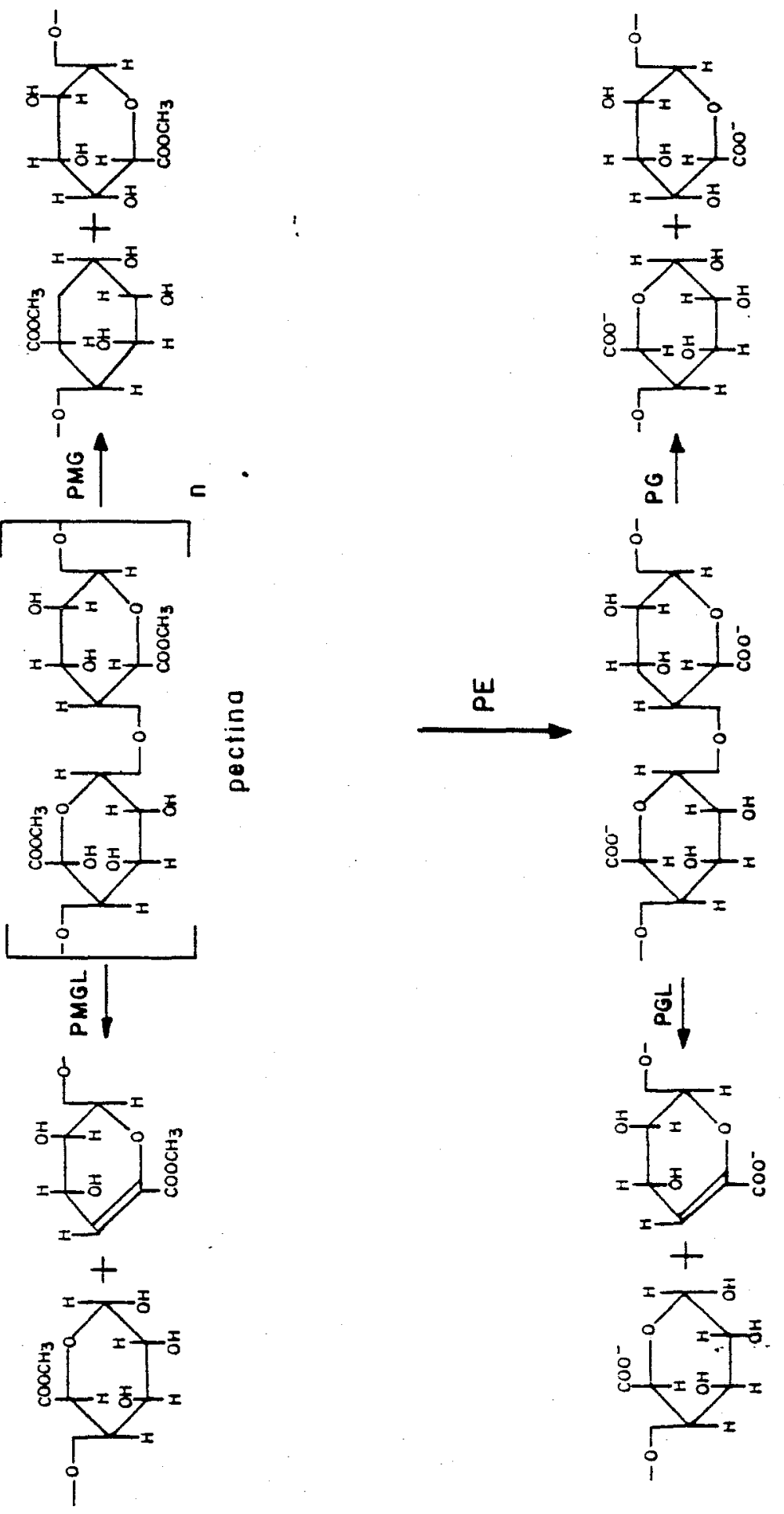

Figura 1: Esquema da molécula de pectina e do modo de ação das enzimas pectinolíticas: polimetilgalacturonase (PMG), poligalacturonato liase (PMGL), pectinesterase (PE), poligalacturonase (PG) e poligalacturonato liase (PGL). Fonte: ROMBOUTS \& PILNIK (1980). 
Segundo ROMBOUTS \& PILNIK (1980), tais enzimas podem ser caracterizadas, levando-se em conta alguns aspectos tais como:

a) tipo de substrato - (pectina, ácido péctico ou oligo -D-galacturonatos);

b) tipo de clivagem - (ataque por hidrólise ou trans-eliminação);

c) mecanismo de ação enzimática - (atuação sobre a molécula do substrato, por clivagem de ligaçōes glicosídicas ao acaso no interior da molécula (endoatividade) ou por clivagem de ligações terminais (exo-atividade).

Em função destes aspectos, as enzimas desesterificantes e despolimerizantes, foram classificadas conforme mostrado na Tabela 1.

\section{TABELA 1 - Classificação das enzimas pectinoliticas}

\section{ESTERASES}

Pectinesterase (PMGE), EC 3.1.1.11, desesterifica pectina para ácido péctico por remoção de resíduos metoxil.

n.s $\left({ }^{*}\right)$; Pectina pectil-hidrolase

n.r. $\left(^{\star *}\right)$; Polimetilgalacturonase esterase

\section{DESPOLIMERASES}

1. Ação sobre pectina

1.1. Polimetilgalacturonase (PMG)

a) Endo-PMG hidrolisa pectina ao acaso

n.s. : Polimetoxilgalactosiduronato glicanohidrolase

n.r. : Endopolimetilgalacturonase

b) Exo-PMG hidrolisa pectina passo a passo

n.s. : Polimetoxilgalactosiduronato exohidrolase

n.r. : Exopolimetilgalacturonase

1.2. Polimetilgalacturonase liase (PMGL)

a) Endo-PMGL, EC 4.2.2.10, ataca a pectina ao acaso por B-eliminação

n.s. : Polimetoxilgalactosiduronato endo liase

n.r. : Endopolimetilgalacturonato liase

(endo pectina liase)

b) Exo-PMGL causa a quebra da pectina sequencialmente por ß-eliminação

n.s. : Polimetoxilgalactosiduronato exo-liase

n.r. : Exopolimetilgalacturonato liase 
Tabela 1 (continuação)

2. Ação em ácido péctico (ácido poligalacturônico)

2.1. Poligalacturonase (PG)

a) Endo-PG, 3.2.1.15, hidrolisa ao acaso o ácido péctico

n.s. : Poli (1,4 - $\alpha$-D-galactosiduronato) glicanohidrolase

n.r. : Endopoligalacturonase

b) Exo-PG-1, EC 3.2.1.67, Hidrolisa sequencialmente o ácido péctico liberando $D$-galacturonatos

n.s. : Poli (1,4- $\alpha$-D-galactosiduronato) galacturonohidrolase

n.r. : Exopoligalacturonase

c) Exo-PG-2, EC 3.2.1.82, hidrolisa o ácido péctico a partir do terminal não redutor, produzindo digalacturonatos

n.s. : Poli (1,4- $\alpha$-D-galactosiduronato) digalacturonohidrolase

n.r. : Exopolidigalacturonase

2.2. Poligalacturonase liase (PGL)

a) Endo-PGL, EC 4.2.2.2., causa a quebra do ácido péctico por ß-eliminação

n.s. : Poli (1,4 - $\alpha$ - D-galactosiduronato) endo liase

n.r. : Endopoligalacturonato liase (endopectato liase)

b) Exo-PGL, EC 4.2.2.9, causa a quebra sequencial do ácido péctico por ß-emilinação

n.s. : Poli (1,4- $\alpha$-D-galactosiduronato) exo liase

n.r. : Exopoligalacturonato liase (exopectato liase)

3. Ação em oligo-D-galactosiduronatos

3.1. Oligogalacturonase (OG)

OG hidrolise oligo-D-galactosiduronatos

n.s. : Oligo-D-galactosiduronato hidrolase

n.r. : Oligogalacturonase

3.2. Oligogalacturonato liase (OGL)

OGL, EC 4.2.2.6, causa a quebra de oligo-D-galactosiduronatos por ß-eliminação

n.s. : Oligo-D-galactosiduronatos liase

n.r. : Oligogalacturonato liase

(*) n.s. = nome sistemático

$\left.{ }^{\star \star}\right)$ n.r. = nome recomendado

Fonte: FOGART \& KELLY (1983). 


\subsection{Produção de enzimas pectinolíticas}

\subsubsection{Fonte comercial de enzimas - aspectos gerais}

Tradicionalmente as enzimas industriais são obtidas a partir de três fontes principais, quais sejam: animais superiores (por ex. pepsina, catalase, renina, etc.), vegetais superiores (por ex. papaina, bromelina, etc) e microrganismos (por ex. amilases, proteases, pectinases, invertase, celulase, etc.).

Tais enzimas, são produzidas por uma diversidade considerável de microrganismos, como por exemplo: Neurospora crassa, Aspergillus niger, Saccharomyces fragilis, Enwinia carotovora, Bacillus mesentericus, dentre outros (PARK, 1970).

As enzimas provenientes de animais são consideradas como subprodutos da indústria de carne, portanto, de produção limitada. Aquelas provenientes de vegetais requerem o crescimento de uma grande quantidade de matéria vegetal para a produção de uma quantidade relativamente pequena de enzima, o que é, do ponto de vista econômico, pouco interessante (PARK \& PAPINI, 1968).

Por outro lado, as enzimas de origem microbiana não apresentam limitação do ponto de vista tecnológico, possibilitando ao produtor um maior controle em sua capacidade produtiva, já que os microrganismos apresentam crescimento relativamente rápido e fácil em meio de cultura. Além disso, niveis enzimáticos podem ser aumentados por manipulaçōes genéticas ou alterações nas condiçōes de cultivo, com maior facilidade se comparado com as de origem animal e vegetal (GASEA \& HUBBLE, [198-]). Portanto, por várias razōes de ordem técnica e econômica, os microrganismos, particularmente aqueles que secretam enzimas, constituem-se nos organismos preferidos da indústria de enzimas (HOLLAND et al., 1986). 


\subsubsection{Enzimas pectinolíticas e sua origem}

Diante do exposto anteriormente, torna-se mais evidente a preferência por fontes microbianas para produções de enzimas, somando-se o fato de que os microrganismos em principio podem fornecer quaisquer enzimas análogas àquelas de origem vegetal ou animal (VITOLO, 1981).

Muitas das enzimas utilizadas atualmente nas indústrias de alimentos se enquadram dentro da categoria hidrolítica. Estas enzimas caracteristicamente despolimerizam seus substratos em pequenos oligômeros elou monômeros (KLACICK, 1988). Entre os vários exemplos que poderiam ser citados, as pectinases serão destacadas por serem foco deste trabalho.

Tais enzimas, tem sido produzidas em muitos paises por uma grande variedade de microrganismos, onde as espécies mais utilizadas sāo: $N$. crassa, A. niger, Penicillium sp, Rhizopus sp, Bacterium aeroideos, $S$. fragilis, Pseudomonas prunicole, Sclerotinia libertiana, Candida subtilis, Aspergillus wentii, Aspergillus oryzae, Trichoderma sp, entre outros (LIMA et al., 1975).

Apesar das pectinases serem produzidas por muitas espécies de fungos, bactérias e algumas leveduras, existem limitaçōes legais para a aplicação de enzimas microbianas na tecnologia de alimentos. Somente são aceitas enzimas derivadas de microrganismos tradicionalmente conhecidos na fermentação de alimentos, pois estes microrganismos comprovadamente não são patogênicos aos seres humanos, sendo então denominados classe GRAS ("Generally Recognized as Safe") (ROMBOUTS \& PILNIK, 1986).

Neste contexto, esta é provavelmente a principal razão pela qual as pectinases comerciais, sejam em sua maioria produzidas por fungos filamentosos, representados pelo gênero Aspergillus. As espécies mais usadas para a produção dessas enzimas em escala industrial, são: Aspergillus wentii, Aspergillus oryzae e Penicillium sp.(Estados Unidos); Aspergillus foetidus (Inglaterra); Aspergillus niger (Suiça); Aspergillus aureus (Alemanha); Sclereotinia libertiana e Corriothyrium diplodiella (Japão), (ENDO, 1962). A preferência pelo gênero Aspergillus, talvez se deva ao fato de que estes, além da habilidade em secretar uma grande variedade de metabólitos secundários e ácidos orgânicos em meio de cultura, não produzem toxinas consideradas nocivas ao homem (GYSLER et al., 1990). 


\subsubsection{Secreção de enzimas microbianas}

Convencionalmente, enzimas extracelulares são definidas como aquelas que atravessam a membrana da célula. Este ponto é importante porque os microrganismos possuem uma variedade de estruturas de parede celular e, em muitos casos, a enzima extracelular está a elas associada.

Durante a sintese dentro de uma célula bacteriana, certas proteinas são reconhecidàs como sendo destinadas para exportação pela presença de um peptídio sinal $\mathrm{N}$-terminal. Estas enzimas extracelulares são parcialmente sintetizadas nos ribossomos livres no citosol antes da junção do complexo (dirigido pelo peptídio sinal $\mathrm{N}$-terminal) com a membrana celular (DEVIS \& TAI, 1980 apud GACESA \& HUBBLE [198-]). A biossíntese da enzima continua então com secreção concomitante ao aumento da cadeia polipeptídica (Secreção co-traducional). Durante o processo de secreção, o peptídio $\mathrm{N}$-terminal é removido por uma peptidase ligada à membrana, como pode ser visto na Figura 2.

Em fungos e outros eucariotos, o processo de secreção é semelhante aquele descrito para células bacterianas. Contudo, durante a síntese, a cadeia peptídica é empurrada através do "lúmem" do reticulo endoplasmático antes que diretamente para dentro da membrana citoplasmática (WALTER et al., 1984, apud GACESA \& HUBBLE, [198-]). A partir do "lúmen" do retículo endoplasmático a enzima é processada através do aparelho de Golgi e é finalmente exportada na forma de vesículas para a membrana celular.

A complexidade encontrada das células eucarióticas permite explicar como as enzimas secretadas são modificadas extensivamente durante sua passagem através do retículo endoplasmático e aparelho de Golgi, conforme Figura 3. 
(a) Formaçōo inicial do complexo ribossomo /RNAm

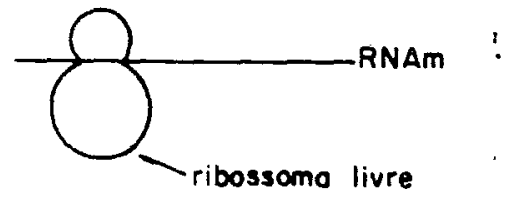

(b) Inicio da biossintese proteica

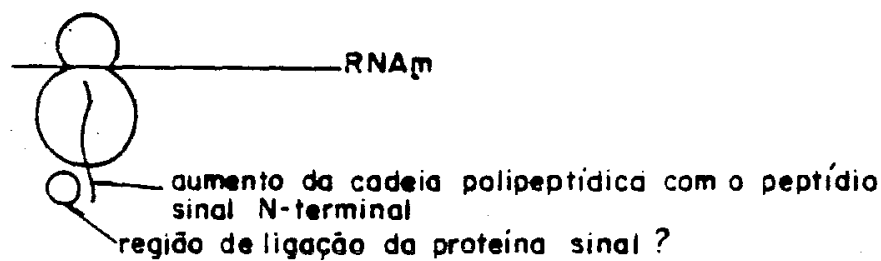

(c) Asptideo sinal dirigindo a interoçäa de ribossoma a mambrana plasmática

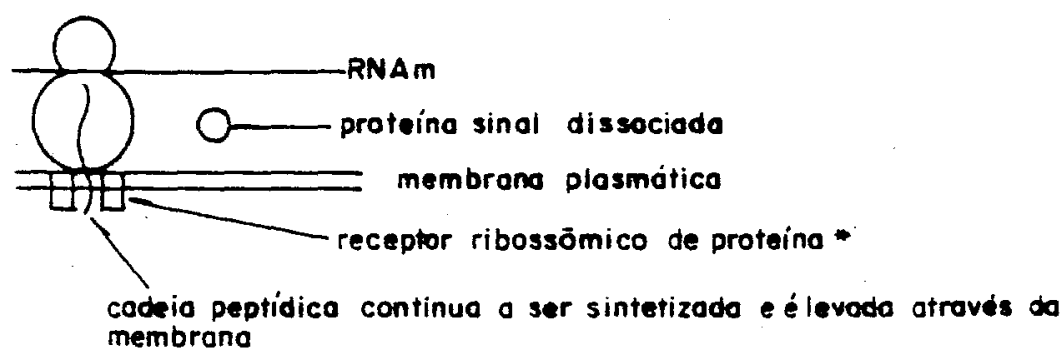

(d) Remocāo do peptidio sinol

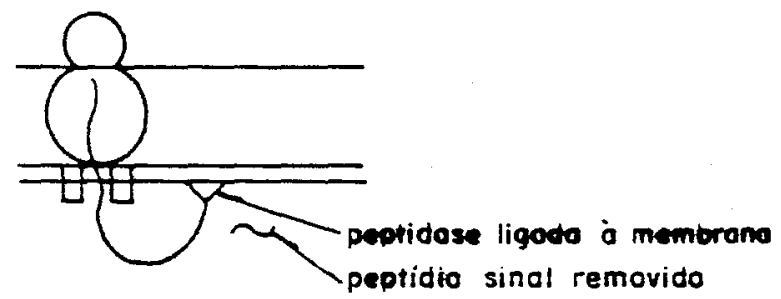

(e) Fim da biossintese protifica

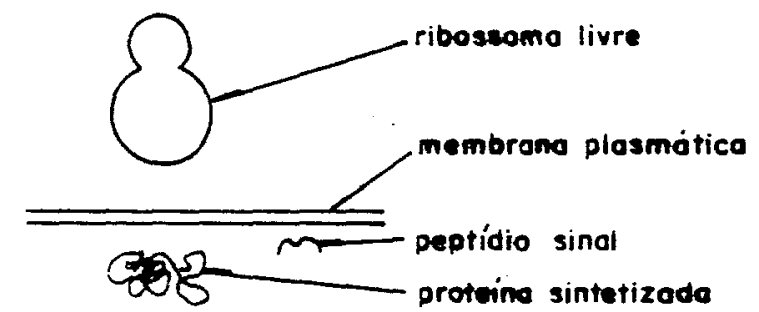

- Embora o sinal de reconhecimento e receptor ribossonal da proteina tenho sido identificado en eucariotos suo presenco em procariotos tem somente sido interido paro estudos genéticos.

Figura 2: Secreção Co-traducional de proteina bacteriana. Fonte: GACESA \& HUBBLE [198-]. 


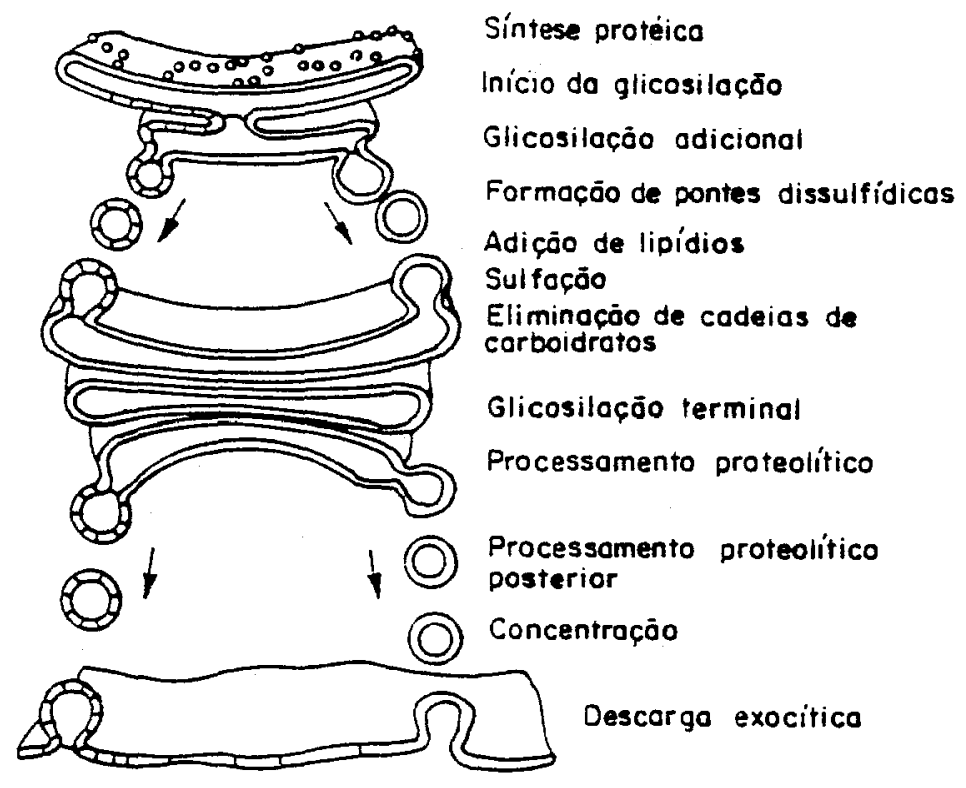

Figura 3: A secreção e processamento de enzimas em eucariotos. Do lado direito do diagrama vê-se o itinerário e concomitante processamento de proteínas secretórias pelos ribossomos ligados a membrana seguidos de exocitose. Do lado esquerdo observa-se como uma proteina integral da membrana feita no retículo endoplasmático usa a mesma via para atingir o seu destino.

Fonte: DUVE (1985). 
Estas modificações pós-traducionais, as quais podem incluir glicosilação, remoção de pequenos fragmentos de peptídio, introdução de pontes disulfídicas dentre outrós, usualmente têm importante influência na estabilidade e propriedade das enzimas (FREEDMAM \& THWKIMS, 1990). Cabe mencionar que, embora este seja um mecanismo geral de operação em eucariotos, existem fungos que não possuem um aparelho de Golgi convencional. Nestes casos o mecanismo de secreção ainda não é conhecido (GACESA \& HUBBLE, [198-]).

Ainda, segundo estes autores, bactérias e fungos são circundados por parede celular que sāo compostas por complexos de peptídeoglicana e ligações $(1 \rightarrow 3)$ glucana/quitina, respectivamente. No caso de bactérias Gram positivas e fungos, as enzimas são usualmente secretadas por difusão através da parede celular para o meio externo. Por outro lado, algumas enzimas permanecem associadas à célula, ligadas à membrana ou à parede celular.

Em bactérias Gram negativas a secreção de enzimas é mais complexa devido à presença da membrana exterior. Conseqüentemente, enzimas secretadas ficam freqüentemente retidas no espaço periplasmático (espaço entre a parede celular e a membrana interna) antes de serem liberadas ao meio de cultura. Esta membrana extra e a localização de diferentes proteinas têm restringido o uso de microrganismos Gram negativos para a produção de enzimas extracelulares.

Para efeito comparativo a Figura 4 mostra as principais diferenças na estrutura da parede celular entre bactérias e fungos. 
(o)

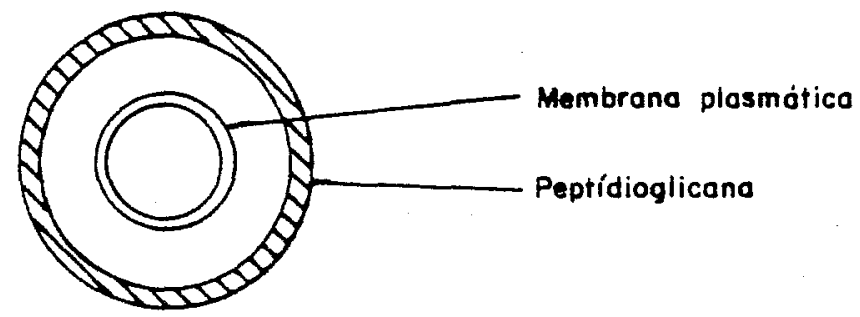

(b)

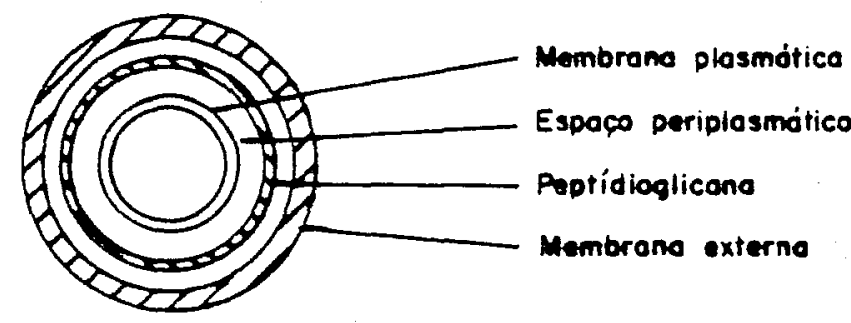

(c)

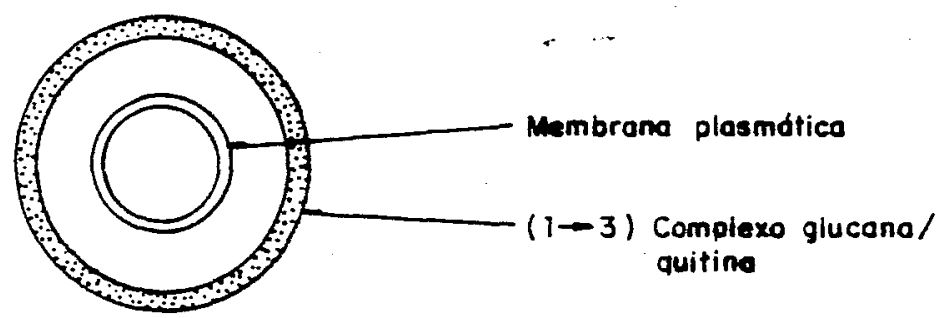

Figura 4 - Representação diagramática de estruturas típicas de parede celular. a) uma bactéria Gram positiva; b) uma bactéria Gram negativa; c) um fungo. Fonte: GACESA \& HUBBLE ([198]). 


\subsubsection{Metabolismo microbiano de poligalacturonatos -} (pectina)

A degradação de substâncias pécticas por enzimas microbianas extracelulares resulta no acúmulo de uma variedade de produtos.

O metanol é formado pela atividade da pectinesterase. O metanol serve como fonte de carbono e energia para uma série de microrganismos que usam este composto, seja obrigatoriamente ou facultativamente. Pectina é a maior fonte de metanol, porém não se conhece nenhum microrganismo que se utilize do metanol para produção de pectinesterase (ROMBOUTS \& PILNIK, 1980).

O ácido D-galacturônico e oligogalacturonatos são os produtos finais da atividade de endopoligalacturonase. Pectatoliases produzem uma série de oligômeros insaturados chamados oligogalacturonatos, dos quais o residuo terminal é um 4,5-dehidrogalocturonato. Pectina-liases produzem metilésteres de oligômeros insaturados.

Poucas pesquisas têm sido realizadas sobre o metabolismo de pectina em fungos e, assim sendo, pouco é conhecido a este respeito. Entretanto, este metabolismo realizado por bactérias tem sido muito estudado nas duas últimas décadas (ROMBOUTS \& PILNIK, 1980).

Aparentemente, a degradação bacteriana de poligalacturonatos leva à produçāo de dois monômeros diferentes, a saber: ácido D-galacturônico e ácido 4-deoxi-L-5-treo-hexoseulose urônico, que são metabolizados por três diferentes vias metabólicas, as quais podem ser observadas na Figura 5. 


\section{ÁCIDO POLIGALACTURÓNICO}

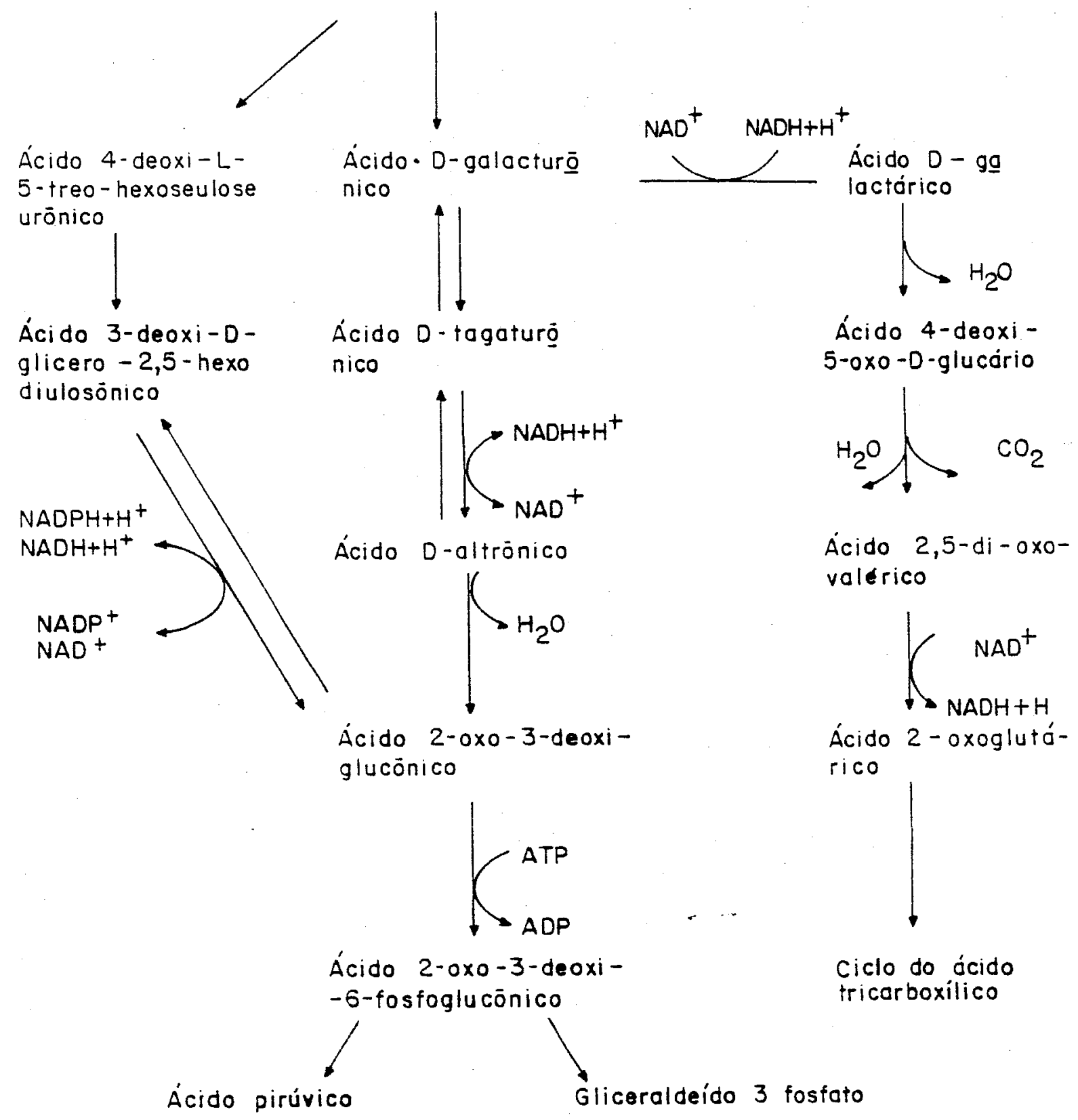

Figura 5: Via metabólica do ácido poligalacturônico em bactéria.

Fonte: ROMBOUTS \& PILNIK (1980). 
0 ácido 4-deoxi-L-5-treo-hexoseulose urônico é inicialmente isomerizado em ácido 3-deoxi-D-glicero-2,5-hexodiulsônico, o qual é reduzido por uma oxode-oxiglucanato desidrogenase em ácido 2-oxo-3-deoxigluconato. Este composto é fosforilado pela oxode-oxigluconato quinase e então metabolizado pela via Entner-Doudoroff.

O ácido D-galacturônico é metabolizado por duas diferentes vias, como demonstrado na Figura 5. Na primeira, o ácido D-galacturônico é isomerizado pela uronato isomerase (EC. 5.3.1.12) em ácido D-tagaturônico. $A$ seguir ocorre a redução pela $D$-altronato desidrogenase (EC. 1.1.1.58) a ácido D-altrônico, o qual é desidratado através da D-manoato hidrolase (EC. 4.2.1.8), formando o ácido 2-oxo-3-deoxi-glucônico. Este composto é fosforilado pela via de Entner-Doudoroff. A via alternativa do ácido D-galacturônico é sua oxidação a D-galactárico, o qual, depois de várias conversōes entra no ciclo dos ácidos tricarboxilicos.

É dificil estimar a importância relativa dessas três vias para bactérias. Entretanto, tem-se demonstrado que a via do ácido 4-deoxi-L-treo-5hexoseulose urônico é mais importante do que a do ácido D-tagaturônico, ao passo que a via do ácido galactárico está restrita a espécies de Pseudomonas e Agrobacterium (ROMBOUTS \& PILNIK, 1980 apud MAIORANO, 1990).

\subsubsection{Controle da produção de enzimas microbianas - fatores que influenciam na produção}

Aspectos importantes referentes a produção de enzimas microbianas têm sido descritos por um grande número de patentes e literatura cientifica. Os procedimentos adotados na produção variam de acordo com os interesses da empresa produtora (WALLERSTEIN, 1911, BECKHORN, 1960, BECKHORN et al., 1965). Contudo, de maneira geral, os métodos de produção de enzimas por fermentação mais utilizados podem ser classificados como: método de cultura submersa e método de cultura semi-sólida (PARK, 1986).

Existem controvérsias, no que diz respeito ao melhor método a ser empregado. Entretanto, nas últimas décadas com os avanços na àrea de Engenharia bioquimica, tem-se observado na literatura pertinente, um crescente interesse pelos processos fermentativos em semi-sólida. Nestas, são 
descatadas as numerosas vantagens que este tipo de cultivo oferece sobre a fermentação submersa (NARAHARA et. al. 1982; GHILDYAL et. al. 1992).

Segundo DEMAIN' (1972) e GACESA \& HUBBLE ([198-]), a otimização da produção de enzimas por microrganismos é dependente de uma série de fatores interrelacionados, tais como: linhagem microbiana utilizada, temperatura, $\mathrm{pH}$, transferência de oxigênio, composição do meio, velocidade de crescimento, indução/repressão pelo produto final, repressão catabólica e manipulação genética, sendỏ alguns destes fatores a seguir abordados.

O substrato e a concentração deste no meio de cultivo é um dos fatores que influencia a produção de enzimas pectinolíticas. FOGART \& KELLY (1983) relatam que a utilização de partes balanceadas de $\mathrm{C} / \mathrm{N}$ e sais minerais, em fermentaçōes submersas, são desejáveis para a produção de enzimas constitutivas. Ainda, segundo estes autores, a maior parte das pectinases comerciais são enzimas indutivas; assim substratos contendo pectina devem ser adicionados no meio para estimular a produção dessa enzima. Estes substratos incluem casca de frutas cítricas, maçã entre outros residuos industriais. Dessa forma, à medida que estes substratos ou produtos degradados derivados destes, tornem-se disponiveis para o organismo, poderiam então induzir um aumento enorme na sintese da enzima.

LARIOS et al. (1989) verificaram que o crescimento de Aspergillus sp em meio de cultivo contendo $2 \%$ de casca de limão não tratada, como susbtrato, resultou numa produção de endopoligalacturonase quatro vezes superior àquela obtida na presença de $2 \%$ de pectina. Entretanto, a produção de exopoligalacturonase foi similar nas duas condiçōes, sugerindo que a primeira enzima é mais sensivel à repressão catabólica exercida pelos produtos da degradação da pectina, os quais se acumulam em curtos periodos de tempo. Verificou-se também que a maior produção enzimática foi obtida quando o meio de cultivo foi suplementado com $3 \%$ do referido resíduo.

Já PETRUCCIOLl et al. (1989) observaram que um aumento na concentração do substrato (resíduo da casca de laranja) de 3,0 para $4,5 \%$ resultava em diminuição no rendimento da enzima produzida por Aureobasidium pullulans, provavelmente devido à repressão da sintese pela presença de açúcares simples prontamente utilizáveis, ou simplesmente porque não se trata do mesmo organismo. 
Um outro fator importante a ser considerado na produção de enzimas pectinolíticas está relacionado à linhagem microbiana a ser utilizada. De maneira geral, a enzima é sintetizada durante parte do ciclo de crescimento, ou seja, algumas proteinas são sintetizadas e secretadas durante a fase exponencial de crescimento podendo, em alguns casos, serem produzidas na fase estacionária (GACESA \& HUBBLE, ([198-]), como pode ser observado no exemplo ilustrado na Figura 6.

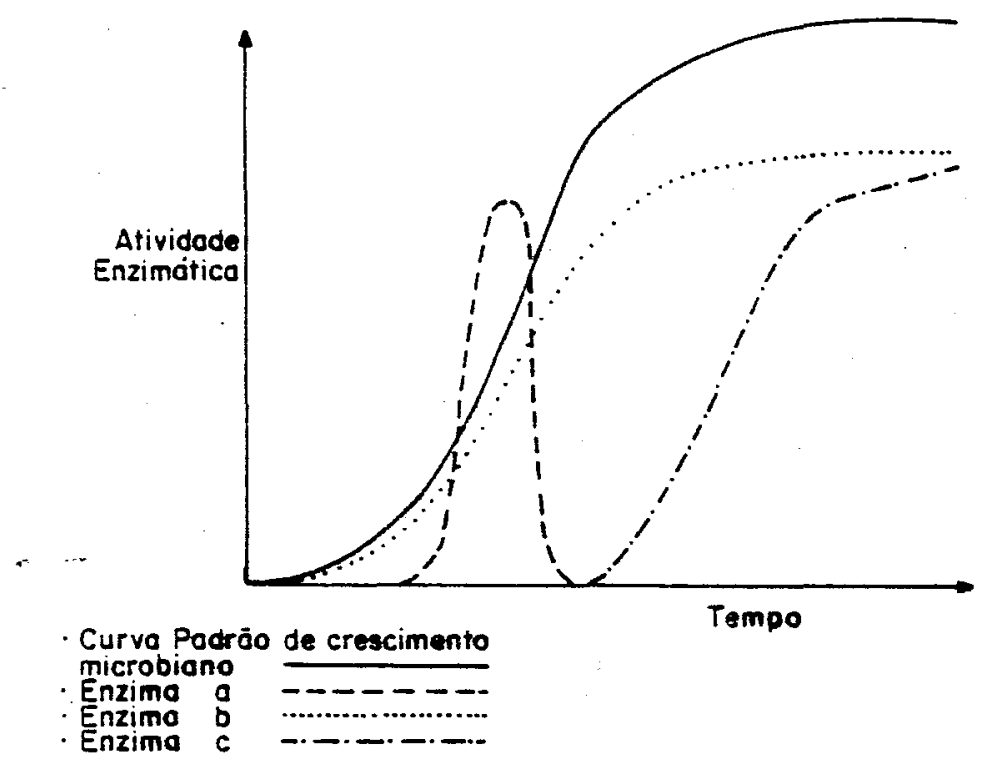

Figura 6: Síntese enzimática como uma função do crescimento microbiano. Três exemplos típicos da produção de enzima por microrganismos estāo ilustrados, embora deva ser enfatizado que alguma situação intermediária é possivel.

Fonte: GACESA \& HUBBLE ([198-]). 
Em vista das variações no comportamento quanto a sintese enzimática, fica evidente a necessidade de maior investigação no que se refere ao controle genético da produção dessas substâncias. Estudos que viessem elucidar a síntese enzimática em fungos filamentosos, poderiam ser extremamente valiosos, já que devido a grande variabilidade encontrada entre espécies associada às alterações nas condições de fermentação poderiam contribuir bastante com modificações desejáveis no perfil de produção inicial (BOOTH \& HIGGINS, 1986).

A sintese das enzimas pectinoliticas por fungos filamentosos é variável qualitativa e quantitativamente, dependendo da espécie e das condições de cultivo utilizados, conseqüentemente, as características bioquímicas das enzimas produzidas também são muito diversas (ROMBOUTS \& PILNIK, 1972).

AGUILAR \& HUITRON (1987), estudando os mecanismos regulatórios, outro importante fator influenciável na produção, verificaram que com a adição do ácido galacturônico ou glicose, em diferentes tempos de cultivo, obtinha-se uma resposta diferencial na produçāo de atividade pectinolítica, quando avaliada pela liberação de grupos redutores e por diminuição da viscosidade. A atividade pectinolítica, avaliada pela liberação de grupos redutores, não foi afetada quando baixas concentraçōes de glicose ou ácido galacturônico foram adicionadas às culturas que estavam crescendo em meio contendo pectina, independente do tempo de adição. Já a atividade pectinolítica, avaliada por diminuição da viscosidade, não foi afetada pela adição da glicose na $24^{a}$ hora de cultivo, mas foi estimulada pela adiçāo de ácido galacturônico no mesmo tempo, sugerindo sua participação na indução dessa atividade. Entretanto, repressão catabólica foi observada quando esses substratos foram adicionados no inicio do cultivo. Ambas atividades pectinolíticas foram fortemente reprimidas quando glicose foi adicionada em altas concentrações e, menos afetada quando ácido galacturônico foi adicionado também em altas concentraçōes.

A produção de poligalacturonase por um mutante de $A$. niger, adenina requerente, foi induzida e sujeita à repressão catabólica. Glicose, frutose ou intermediários de glicólise, mas não intermediários do ciclo do ácidos tricarboxilicos, reprimiram a síntese da enzima, sendo que a repressão 
catabólica por glicose ocorreu rapidamente e quase por completo (ROMBOUTS \& PILNIK, 1980).

MALDONADO et al. (1989) estudaram a repressão catabólica da sintese de poligalacturonase e pectinesterase induzidas por A. niger sp., isolada de limão, em estado de degradação, e verificaram que tais enzimas eram reprimidas pela glicose, até mesmo na presença do indutor. A produção de ambas as enzimas iniciaram novamente quando $o$ açúcar foi consumido, ou quando o micélio foi lavado e incubado em novo meio contendo indutor e livre de glicose, demonstrando a reversibilidade do mecanismo de repressão. 0 efeito da glicose foi também testado na ausência da transcrição através da utilização de um repressor actinomicina (Am), ocorrendo aumento da produção de pectinesterase nas primeiras 4 horas e cessando a seguir. Quando usaram cicloheximida $(\mathrm{CH})$, um repressor de tradução, a produção de pectinesterase decaiu marcantemente. Os resultados obtidos sugeriram que a repressão ocorre a nivel traducional.

Vale também mencionar outros fatores, como $\mathrm{pH}$ e temperatura, os quais também sảo importantes parâmetros de avaliação durante a produção enzimática. MANACHINI et al. (1988) verificaram que Aureobasidium pullulans LV 10 produziu atividade pectinolítica extracelular quando cresceu em meio contendo pectina de maça, como fonte de carbono. Após concentração por ultrafiltração, duas hidrolases e duas liases foram parcialmente purificadas em colunas cromatográficas com CM-Sepharose 6B, DEAE-celulose e Sephadex G-100. As hidrolases I e II deram atividade ótima a $50^{\circ} \mathrm{C}$ em pH 5,5 e 4,5 respectivamente. Para liases I e 11 , o pH ótimo era 5,0 e 7,5 respectivamente, a $40^{\circ} \mathrm{C}$. Outros autores demonstraram que a maior produção de poligalacturonase ocorre em $\mathrm{pH}$ ácido, geralmente em torno de 3,0 a 4,0 (LARIOS et al., 1989, PETRUCCIOLI et al., 1989, BAILEY \& PESSA, 1990).

A temperatura ótima de crescimento e produção de pectinase parece depender do microrganismo utilizado. LARIOS et al. (1989), trabalhando com Aspergillus $s p$, verificaram que ocorreu maior crescimento e produção de atividade pectinolítica quando as culturas foram incubadas a $37^{\circ} \mathrm{C}$. PETRUCCIOLl et al. (1989) obtiveram maior produção dessas enzimas por Aureobasidium pullulans quando a temperatura de cultivo foi $24^{\circ} \mathrm{C}$; e todas as linhagens de Cylindrocarpen destructans, patogênicas ou não, tiveram a 
de exo e endopolimetilgalacturonase diferentemente afetadas por várias temperaturas e valores de $\mathrm{pH}$ (STRZELCZYK et al., 1987).

\subsection{Importância e aplicação de enzimas pectinoliticas}

O uso de enzimas remonta milhares de anos, as quais basicamente tem sido utilizadas nas Indústrias de Alimentos, Bebidas, Têxtil, Papeleira e Farmacêutica. ìsto se deve principalmente às vantagens que estes biocatalisadores apresentam, como por exemplo: alta especificidade, maior atividade, etc. (MAIORANO, 1990).

Atualmente, enzimas microbianas são usadas para melhorar 0 processo industrial, ou seja, para capacitar a utilização de novos tipos de matéria-prima ou para melhorar as propriedades físicas do material. Também são usadas para melhorar produtos, alterando cor, aroma, textura, sabor, ou tempo de prateleiras de gêneros alimentícios, assim como para torná-los mais aceitáveis junto ao consumidor (WISEMAN, 1985).

As enzimas pectinolíticas constituem-se num importante grupo dentre as enzimas microbianas. A maioria das enzimas pécticas são formadas por uma mistura complexa de tipos distintos de enzimas. Essa mistura geralmente contém pectinesterase e poligalacturonase, e provalvemente outras mais, sendo produzidas por várias espécies de Aspergillus e Penicillium (LINEWEAWER \& JANSEN, 1951; PARK \& PAPINI,1968).

A utilização das enzimas pectinolíticas tem ocorrido principalmente nas indústrias de alimentos, sendo na clarificação de sucos de frutas sua maior aplicação (ROMBOUTS \& PILNIK, 1980). A adição de enzimas pécticas à uva ou outras frutas, antes da moagem ou esmagamento, resulta em aumento do suco no momento da prensagem. O caldo resultante das frutas assim tratadas tornam-se geralmente mais claro, limpido e apresenta melhor coloração (LINEWEAVER \& JANSEN, 1951).

A turvação dos sucos de frutas dificilmente é removida por filtração, dado a grande quantidade de material em suspensão que estes sucos contêm. Isso acontece devido à ação coloidal da pectina da fruta original. Ao contrário, o suco de frutas previamente tratado com enzimas pécticas é mais facilmente clarificado por filtração, sendo que a ação dessas enzimas não 
altera a cor e nem o gosto do suco final (PARK \& PAPINI, 1968).

O suco de pêra também tem sido tratado com pectinase, resultando numa queda rápida da viscosidade e na diminuição da turbidez, formando flocos que sedimentam. Após a filtração ou centrifugação, obtem-se um suco claro. No caso do suco de maçã, a diminuição da viscosidade pode ser causada pela atividade combinada de pectinesterase $e$ endopoligalacturonase na. solução de pectina altamente esterificada. A clarificação é também possivel pela atividade da pectina liase (ROMBOUTS \& PILNIK, 1980).

As enzimas pécticas são bastante usadas na produção de sucos de alta densidade. Na elaboração do suco de maçã concentrado é necessária e indispensável a adição dessas enzimas para remoção de toda a pectina existente, caso contrário, haveria formação de gel e, conseqüente depreciação do produto. No processamento para obtenção de sucos de frutas, normalmente estes são despectinizados e filtrados antes da concentração (PARK \& PAPINI, 1968).

As preparações comerciais de enzimas pécticas usadas na indústria de alimentos, geralmente originam-se de fungos, especialmente do Aspergillus niger. Tais fontes normalmente contém uma mistura de enzimas pécticas, geralmente associadas com hemicelulases e/ou celulases, utilizadas nos processos que requerem somente um tipo de enzima pectinolítica. É o caso, por exemplo, do uso da endopoligalacturonase na preparação de suco de laranja. Foi mostrado que o suco pode ser estabilizado pelo uso de altos niveis de atividade de poligalacturonase (ROMBOUTS \& PILNIK, 1980).

A aplicação industrial das enzimas pectinolíticas nos processos de maceração é encontrada na produção de purês e alimentos para bebês, bem como no tratamento preliminar de café, cacau e fibras de plantas, visando a remoção da polpa indesejada da fruta (CALL et al., 1985).

A maceração pode ser realizada por uma pectinase relativamente rica em endopoligalacturonase e quase livre de pectinesterase e pectina liase. Esta preparação degrada a pectina da lamela média, a qual possui baixo grau de esterificação. Entretanto, a maceração pode também ser feita com uma pectina liase pura. Se celulase é usada em associação às enzimas pécticas, uma liquefação quase completa dos frutos e vegetais pode ser conseguida 
(ROMBOUTS \& PILNIK, 1980). Uma aplicação biotecnológica importante das enzimas macerantes é o isolamento de protoplastos de células vegetais (SREENATH et al., 1986).

As enzimas pectinolíticas são utilizadas também na valorização dos subprodutos da indústria citrica (polpa lavada) e no isolamento de óleos essenciais e pigmentos carotenóides da casca de citrus (ROMBONTS \& PILNIK, 1980).

\subsection{Isolamento e seleção de fungos produtores de enzimas pectinolíticas}

A seleção apropriada de microrganismos constitui a primeira e mais importante fase na produção de qualquer enzima comercial (PARK, 1968). $O$ isolamento envolve a obtenção de culturas puras, seguido de avaliação quanto à atividade ou produção da enzima de interesse. Em alguns casos, métodos direcionados de isolamento, como por exemplo a técnica de enriquecimento, tem sido usados. Em outros casos, dá-se preferência pelo isolamento aleatório. De qualquer modo devem ser estabelecidos parâmetros entre a produtividade do microrganismo e o contexto econômico do processo (STANBURY \& WHITAKER, 1984).

BULL et al. (1979) citaram alguns pontos importantes a serem considerados como critérios na escolha do organismo, quais sejam:

1) Caracteristicas nutricionais interessantes, ou seja, capacidade de utilizar meios baratos, com fontes de energia mais acessivel;

2) Temperatura ótima, de crescimento e/ou produção;

3) Adequação das condições do processo ao microrganismo;

4) Estabilidade do microrganismo e a sua tratabilidade para manipulações genéticas;

5) A produtividade do organismo, medida na sua capacidade de converter o substrato em produto, além de apresentar um alto rendimento do produto por unidade de tempo;

6) Fácil recuperação do produto. 
Segundo BULL et al (1979), os quatro últimos critérios podem ser avaliados em testes detalhados, subsequentemente ao isolamento. $O$ microrganismo selecionado com base nestes resultados deverá gerar um processo economicamente viável. Contudo, antes do processo ser colocado em operação, a toxicidade do produto e do microrganismo também devem ser avaliadas.

Ambientes naturais são a principal fonte na obtenção de tais microrganismos. Os microrganismos também podem ser selecionados entre linhagens obtidas de coleçōes de cultura. MARTIN \& SKERMAN (1972) citaram várias coleções de cultura bastante conhecidas, como a: NCTC - National Collection of Type Cultures (Inglaterra); ATCC - American Type Culture Collection (USA); Collection Nationale de Cultures de Microrganismes (França), entre outras. Entretanto, apesar de tais coleções possuirem em seu acervo microrganismos com caracteristicas conhecidas, nem sempre estes possuem a maioria dos aspectos desejados, ao passo que o ambiente natural, com sua microbiota rica, pode permitir 0 isolamento de microrganismos com caracteristicas satisfatórias.

Provavelmente, a aquisição de culturas em coleções teria um custo reduzido se comparado ao isolamento de fontes naturais; por outro lado, é possivel que um microrganismo superior possa ser encontrado após exaustiva busca em ambientes naturais (STANBURY \& WHITAKER, 1984). Talvez seja por esta razāo que os procedimentos de isolamento normalmente são a partir de fontes ambientais (freqüentemente solo), a exemplo de PARK et al. (1972), que descreveram o isolamento de mais de 200 espécies entre fungos, bactérias e leveduras, onde o critério seletivo foi a capacidade de produção de enzimas pectinoliticas extracelulares, por meio de clarificação do suco de várias frutas.

O meio sólido tem sido bastante utilizado para 0 isolamento e seleção de linhagens produtoras de enzimas. Esta técnica usualmente envolve o emprego de um meio seletivo, contendo o substrato específico da enzima, o qual favorece $O$ isolamento de linhagens possivelmente capazes de sintetizar o metabólito de interesse (STANBURY \& WHITAKER, 1984). Variações no método de seleção em placas (meio sólido) tem sido descrito (HANKIN \& ANAGNOSTAKIS, 1975; MCKAY, 1988; TSUYUM et al., 1989), tanto para 
detecção de enzimas pectinolíticas produzidas por fungos, quanto para diferenciação entre as enzimas encontradas neste complexo.

A seleção em meio sólido pode ser feita por avaliação semiquantitativa através do índice de relação enzimática, obtido pela divisão entre a medida do diâmetro do halo de degradação que apresenta uma zona clara no ágar, após precipitacão do substrato intacto, e a medida do diâmetro da colônia. Desta maneira, a atividade de variantes de algumas espécies pode ser examinada. Contudo a relação pode não ser válida, ressalta HANKIM \& ANAGNOSTAKIS, (1975), quando espécies diferentes são comparadas entre si.

Apesar deste método ser rotineiramente usado para "screening" rápido, é necessária devida cautela, já que nem sempre existe correlação entre os dados encontrados em placas (meio sólido) e aqueles obtidos em fermentações submersas. AUNSTRUP et al. (1972), testando diferentes espécies de Bacillus quanto à produção de protease alcalina, não encontraram correlação entre os métodos semiquantitativo (meio sólido) e o quantitativo (meio líquido).

\subsection{Preservação de linhagens fúngicas produtoras de enzimas pectinolíticas}

O isolamento de microrganismos para uso em processos industriais pode ser um procedimento longo, árduo e, às vezes, muito caro. Linhagens industrialmente empregadas, quer sejam novos isolados ou linhagens padrōes, melhoradas ou nāo, constituem a base para a boa realização dos processos pelos quais tais culturas são responsáveis. Assim sendo, é essencial que sejam mantidas suas características de interesse. A seleção de métodos adequados à manutenção não constitui assunto recente (GREENE \& FRED, 1934), sendo considerada por alguns autores täo importante quanto o próprio melhoramento genético.

A utilização de um único método de manutenção até se adquirir ampla experiência com determinados microrganismos é freqüentemente desaconselhada, já que a produção de substâncias industrialmente importantes pode depender de fatores ligados ao método de preservação empregado 
(CALAM, 1964, KIRSOP, 1986). Entre tais fatores, destacam-se não apenas a manutenção de altos niveis de viabilidade celular, como características morfofisiológicas e taxonômicas, além da prevenção de contaminações indesejáveis.

A literatura especializada é rica na descrição de procedimentos aplicáveis a diferentes gêneros e espécies (KIRSOP, 1984, SMITH \& ONIONS, 1983, GROUT et al., 1993). Um só método dificilmente é considerado amplamente aplicável a qualquer espécie e a escoiha do método é dependente não só da experiência, dos materiais e equipamentos disponiveis, bem como das características particulares e demanda da cultura em questão. Em geral, no entanto, a literatura serve como guia, mas o assunto muitas vezes ainda depende da experiência empírica (HILL, 1981).

Naturalmente, cada método apresenta vantagens e desvantagens as quais devem ser consideradas, ao lado dos fatores acima mencionados, na ocasião da escolha. Culturas fúngicas podem ser mantidas tanto em forma de micélio, como de esporos.

Subcultivos periódicos são amplamente utilizados na preservação de pequenas coleções de fungos, tendo como principais desvantagens a constante possibilidade de contaminação a cada repique, erro de rotulação ou de protocolos, seleção de clones mais resistentes ao stress do estoque prolongado, além de ser trabalhoso e dispendioso em termos de custo de meio de cultura e espaço para o armazenamento. Micotecas sofrem freqüentemente - risco adicional de se contaminarem por ácaros micófagos que, além de destruírem as culturas, carregam contaminações à medida que infestam diferentes tubos (SMITH \& ONIONS, 1983, HILL et al., 1991). Variação de linhagens, alterações de patogenicidade ou outras características fisiológicas e morfológicas têm sido reportadas após o emprego deste método.

A aplicação de uma camada de óleo mineral cobrindo culturas em agar inclinado é outro modo de preservação empregado, prevenindo a desidratação e diminuindo a atividade metabólica através da redução da tensão de oxigênio. Este procedimento foi descrito em décadas passadas (BUELL \& WESTON, 1947), sendo empregado em alguns laboratórios com sucesso. Entretanto, não está livre da contaminacão de esporos aéreos; algumas culturas apresentam crescimento lento quando da recuperação, 
passagens sucessivas podem ser altamente seletivas, além da recuperação ser dificultada. O método requer atencão especial culturas patogênicas, pois na presença do óleo, quando se flamba a alça durante a recuperação ocorre um espalhamento do material nela contido, podendo causar contaminações (SMITH \& ONIONS, 1983).

A manutenção de esporos dispersos em solo estéril, distribuídos em frascos rosqueados e armazenados em refrigerador tem se mostrado um método eficiente na manutenção por longos períodos; com razoável estabilidade. A umidade inicial deste ambiente permite um breve crescimento antes da cultura entrar em fase de latência, entretanto, em alguns casos verificou-se a emergência e predominància de mutantes durante esta fase de crescimento (BOOTH, 1971). O baixo custo e a facilidade de recuperação das células são vantagens adicionais deste método, embora haja necessidade de espaço para armazenamento sob refrigeração.

A suspensāo de esporos em água destilada é um outro método descrito por CASTELLANI (1967) e usado com sucesso mesmo para algumas células na sua forma vegetativa (SILVA et al., 1992). Blocos de agar contendo culturas fúngicas também têm sido estocados suspensos em água. A literatura não apresenta explicaçōes razoáveis para o sucesso deste método, especialmente para células vegetativas. As vantagens apresentadas são semelhantes às do emprego-de solo e, como desvantagens, além das citadas para o uso de solo, reside a emergência de colônias "petites" no caso de leveduras (SILVA, 1990).

Os métodos comentados são de baixo custo, sendo apropriados para coleçōes com pẹqueno número de cultura por não requererem equipamentos sofisticados e serem de fácil execução.

A secagem é uma outra forma largamente empregada na preservação microbiana, e no que se refere aos fungos, muitos são os esporos capazes de sobreviver a condiçōes de secagem, recuperando-se quando as condições de umidade são restabelecidas. Parece razoável imaginar que tais fungos apresentam esta capacidade graças à parede espessa de seus esporos.

Este método de secagem pode ser feito utilizando-se vários suportes como solo, silica-gel, celulose, pérolas de vidro, discos de gelatina, 
etc. (PERKINS, 1962, THOMPSON, 1987, MALIK, 1988). Esta é a forma mais simples de se suprimir o metabolismo, embora a maioria das culturas não sobrevivam à secagem pura e simples em laboratório, algumas sobrevivem por muitos anos, como é o caso dos gêneros Penicilium e Aspergillus. Este método de preservação é bastante suscetivel a infestação por ácaros, possibilitando também a introdução de outros contaminantes cada vez que uma amostra é manipulada. Apesar do baixo custo da prevenção a infestação por ácaros, sua aplicação tem sido limitada a fungos capazes de esporular (SMITH, 1984).

A liofilização consiste numa forma de secagem de esporos fúngicos a vácuo após o congelamento suspensos em substâncias protetoras, cuja funçảo é a prevenção de danos advindos do congelamento em si e da própria secagem (PITOMBO, 1989). É um método apropriado para manutenção de altos niveis de viabilidade por longos periodos, não requerendo tanto espaço, pois pequenos volumes são liofilizados $e$ armazenados em ampolas em refrigerador doméstico. Além disso, a facilidade de distribuição de ampolas para outros laboratórios, e a facilidade de se preparar várias ampolas de uma só vez, são vantagens adicionais quando se tem grande número de culturas a manipular (KIRSOP, 1983).

Entretanto, requer equipamento apropriado e apenas aquelas linhagens capazes de apresentar esporulação abundante podem ser submetidas a este método, já que células miceliais não resistem ao stress causado pela liofilização. Neste aspecto, o crescente emprego, nas últimas décadas, de conservação a temperaturas ultra baixas, próximas à do nitrogênio líquido, têm se mostrado mais eficiente para algumas espécies, o que enfatiza à necessidade de seleção do método adequado a espécies de interesse (SILVA, 1990).

O emprego da criopreservação reduz a atividade metabólica, de modo que alterações fenotípicas ou genotipicas sejam diminuídas, desde que certos cuidados sejam tomados durante o congelamento e descongelamento, como o abaixamento lento da temperaura em uma fase inicial $\left(1^{\circ} \mathrm{C} / \mathrm{min}\right)$ e recuperação por um aquecimento rápido a $37^{\circ} \mathrm{C}$.

O método acima pode ser aplicado à culturas fúngicas capazes ou nāo de esporular e a resposta negativa de algumas espécies tem sido atribuída a pequenos erros técnicos que podem ser ajustados, já que mesmo 
células animais têm sido mantidas com sucesso por este método.

O uso de protetores apropriados, bem como a condição de cultivo são fatores de grande relevâncià à semelhança da liofilização (KIRSOP, 1984, SILVA, 1992). A principal desvantagem neste caso reside no custo do equipamento e a necessidade de constante fornecimento de nitrogênio líquido que se não houver, resulta na perda das culturas.

Pelo exposto, conclui-se que a necessidade do emprego de mais de uma forma de conservaçāo é o procedimento mais seguro em situações nas quais não se conhecem as características das linhagens estudadas, como é o caso de novos isolados, mutantes e melhorados, bem como na preservação de culturas interessantes sob o ponto de vista industrial.

As principais coleçōes de culturas no mundo empregam a liofilização e a criopreservação em nitrogênio líquido, pois manipulam grande número de linhagens e tais métodos apresentam as vantagens já descritas, além de manterem altos niveis de viabilidade. Os demais procedimentos descritos não estão, todavia, descartados, pois devem ser levados em consideração na escolha do método, os recursos disponiveis em cada laboratório, o número e necessidade de distribuição, bem como o valor de cada cultura (SILVA, 1990, SILVA, 1992). 


\section{MATERIAL E MÉTODOS}

\subsection{Microrganismos utilizados}

\subsubsection{Isolados selvagens}

As linhagens fúngicas isoladas no presente trabalho foram obtidas a partir de amostras de solo coletadas no Sítio Paredão Vermelho Arthemis/SP, Fazenda Monte Belo - Colina/SP (ambas regiōes de plantio de frutas citricas), e de solo de Jardim Doméstico. Também foram realizados isolamentos a partir de frutas em estado de degradação como laranja, maracujá e uva, objetivando a obtenção de fungos capazes de degradar a pectina, ou seja, fungos pectinolíticos.

\subsubsection{Linhagens advindas de coleçōes de cultura}

Também foram testadas as linhagens fúngicas existentes no Laboratório de Microbiologia Industrial / $A B / D Q$, do Instituto de Pesquisas Tecnológicas do Estado de São Paulo, S/A - IPT.

1 - $A$. niger NRRL-377

(FP/102)

2 - A. niger NRRL-3122

(FP/103)

3 - A. niger ATCC-1025 (IZ-150)

(FP/104)

4 - A. awamori AWG-547

5 - A. awamori NRRL-3112

6 - A. oryzae

(FP/107)

7 - A. tamarii

(FP/108) 
As linhagens 1 à 5 foram gentilmente cedidas pelo Laboratório de Engenharia Bioquímica da EPUSP (Escola Politécnica da USP).

A linhagem 6 cedida pela FEI (Faculdade de Engenharia Industrial), e a linhagem 7 cedida pela EMBRAPA (Empresa Brasileira de Pesquisas Agropecuárias - RJ).

\subsection{Manutenção das linhagens e obtenção de esporos}

Todas as linhagens aqui utilizadas foram mantidas em cultura pura através de repiques sucessivos em meio sólido inclinado (ATCC - 325, ATCC - MEDIA HANDBOOK, 1984).

Os repiques foram realizados através de transferências assépticas (com alça de platina) de uma pequena porção do micélio, para tubos de ensaios contendo o meio sólido indicado acima.

A nova cultura foi incubada, durante 5 a 7 dias, em estufa bacteriológica a $30^{\circ} \mathrm{C}$ e os esporos formados foram utilizados para inocular meios de cultura líquidos ou sólidos para os estudos previstos, ou então, estes tubos foram mantidos sob refrigeração $\left(4^{\circ} \mathrm{C}\right)$, para estoque.

Para o primeiro propósito, coletavam-se os esporos assepticamente em solução de Tween $80(0,01 \%$ VN) estéril, agitando-se levemente. A seguir determinava-se a concentração de esporos desejada por contagem em câmara de Neubauer sob microscópio óptico.

\subsection{Esterilização e incubação}

Os meios de cultura e soluções aqui utilizados foram esterilizados em autoclave, por 30 minutos, a $121^{\circ} \mathrm{C}$ e 1 atm. $A$ incubação sempre foi realizada a uma temperatura de $30^{\circ} \mathrm{C}$. 
3.4. Meios de cultura e soluções utilizados

3.4.1. Meio Malt Extract Agar (Blakeslee's Form) - ATCC - 325 (ATCC MEDIA HANDBOOK), 1984

$\begin{array}{ll}\text { Extrato de malte } & 20.0 \mathrm{~g} \\ \text { Glicose } & 20.0 \mathrm{~g} \\ \text { Peptona } & 1.0 \mathrm{~g} \\ \text { Ágar } & 20.0 \mathrm{~g} \\ \text { Água destilada } & 1000 \mathrm{ml}\end{array}$

3.4.2. Meio de Hankin (MH) (Hankin \& Anagnostakis, 1975)

Solução A

Extrato de levedura

Pectina citrica

Ágar

Água destilada

$1.0 \mathrm{~g}$

$5.0 \mathrm{~g}$

$15.0 \mathrm{~g}$

$500 \mathrm{ml}$

Solucão B (sais minerais)

$\left(\mathrm{NH}_{4}\right)_{2} \mathrm{SO}_{4}$
$\mathrm{KH}_{2} \mathrm{PO}_{4}$
$\mathrm{Na}_{2} \mathrm{HPO}_{4}$
$\mathrm{FeSO}_{4} 7 \mathrm{H}_{2} \mathrm{O}$
$\mathrm{CaCl}_{2}$
$\mathrm{H}_{3} \mathrm{BO}_{3}$
$\mathrm{MnSO}_{4}$
$\mathrm{ZnSO}_{4}$
$\mathrm{CuSO}_{4}$
$\mathrm{MoO}_{3}$
Agua destilada

$2.0 \mathrm{~g}$

$4.0 \mathrm{~g}$

$6.0 \mathrm{~g}$

$0.2 \mathrm{~g}$

$10.0 \mathrm{~g}$

$10.0 \mu \mathrm{g}$

$10.0 \mu \mathrm{g}$

$70.0 \mu \mathrm{g}$

$50.0 \mu \mathrm{g}$

$10.0 \mu \mathrm{g}$

$500.0 \mathrm{ml}$

O meio acima citado, quando utilizado, sofreu variações:

Modificacão 1 - MH - Sólido

Neste caso, a solução $A$ foi preparada como indicado e seu pH ajustado para $7.0 \mathrm{com} \mathrm{NaOH} 4 \mathrm{~N}$. 
A solução B teve ajuste de seu pH para 3.5 - 4.0 com ácido sulfúrico antes da autoclavação. Após a esterilização, a mistura das soluções $A$ e B sofreu novo ajuste de $\mathrm{pH}$ para $3.5-4.0$ com ácido tartárico esterilizado $30 \%(P N)$.

\section{Modificacão 2 - MH - Líquido}

Nesta, o preparo das soluções A e B sofreu alterações. A solução A foi preparada sem adição do agar e da solução $B$, suprimiu-se $\mathrm{Na}_{2} \mathrm{HPO}_{4}$; ambas as soluçōes foram dissolvidas em tampäo citrato-fosfato, para que o $\mathrm{pH}$ desejado 3.6. fosse alcançado.

3.4.3. Meio minimo (PONTECORVO et al., 1953)

$\begin{array}{ll}\mathrm{NaNO}_{3} & 5.0 \mathrm{~g} \\ \mathrm{KH}_{2} \mathrm{PO}_{4} & 1.5 \mathrm{~g} \\ \mathrm{Kcl} & 0.5 \mathrm{~g} \\ \mathrm{MgSO}_{4} .7 \mathrm{H}_{2} \mathrm{O} & 0.5 \mathrm{~g} \\ \mathrm{FeSO}_{4} & 0.01 \mathrm{~g} \\ \mathrm{ZnSO}_{4} & 0.01 \mathrm{~g} \\ \text { Glicose } & 10.0 \mathrm{~g} \\ \text { Ágar } & 15.0 \mathrm{~g} \\ \text { Ägua destilada } & 1000 \mathrm{ml}\end{array}$

$\mathrm{O} \mathrm{pH}$ foi ajustado para $6.8 \mathrm{com} \mathrm{NaOH} 1 \mathrm{~N}$.

3.4.4. Meio completo (Pontecorvo et al., 1953, modificado por AZEVEDO \& COSTA, 1973).

Foram adicionados ao meio mínimo:

Peptona

Caseina hidrolizada

Extrato de levedura

Soluções de vitaminas
$2.0 \mathrm{~g}$

$1.5 \mathrm{~g}$

$2.0 \mathrm{~g}$

$\mathrm{O} \mathrm{pH}$ foi ajustado para 6.8. com $\mathrm{NaOH} 1 \mathrm{~N}$. 
3.4.5. Soluções de vitaminas

Ácido nicotínico

$100.0 \mathrm{mg}$

Ácido paraminobenzóico:

$10.0 \mathrm{mg}$

Biotina

Piridoxina

$0.2 \mathrm{mg}$

Riboflavina

$50.0 \mathrm{mg}$

Tiamina

$100.0 \mathrm{mg}$

$50.0 \mathrm{mg}$

A solução foi esterilizada em banho-maria a $90^{\circ} \mathrm{C}$, por 20 minutos e conservada sob clorofórmio, em frasco escuro, no refrigerador.

\subsubsection{Solução tampão de Mcllvaine, (MCLLVAINE, 1921)}

Soluçäo A

Ácido cítrico $0,1 \mathrm{M}$

Água destilada

$19.21 \mathrm{~g}$

$1000 \mathrm{ml}$

Solucão B

Fosfato dibásico de sódio $\left(7 \mathrm{H}_{2} \mathrm{O}\right) \quad 53.65 \mathrm{~g}$

Água destilada $1000 \mathrm{ml}$

Tomaram-se $33.9 \mathrm{ml}$ da Solução A e $16.1 \mathrm{ml}$ da Solução B para um total de $100 \mathrm{ml}$, ajustado com água destilada, obtendo-se assim um pH em torno de 3.6.

\subsubsection{Solução tampão acetato (MAIORANO, 1990)}

Solucão A

Ácido acético

Água destilada

$3.0 \mathrm{~g}$

$100.0 \mathrm{ml}$

Solucão B

Acetato de sódio

Água destilada

$10.0 \mathrm{~g}$

$100.0 \mathrm{ml}$ 
Soluçäo C

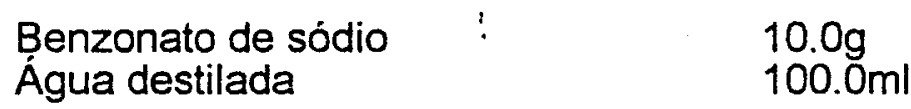

Para obtenção da solução tampão acetato $\mathrm{pH}=4$, tomaram-se $73.6 \mathrm{ml}$ da Solução A mais $26.4 \mathrm{ml}$ da Solução B e $2.5 \mathrm{ml}$ da Solução C, completando-se o volume para $1000 \mathrm{ml}$ com água destilada.

\subsubsection{Solução salina}

$\mathrm{NaCl}$

Água destilada

$0.85 \mathrm{~g}$

$100.0 \mathrm{ml}$

\subsubsection{Solução "Tween 80 " $(0.01 \%$ v/v)}

Tween 80

Água destilada
$0.01 \mathrm{ml}$

$100.0 \mathrm{ml}$

\subsubsection{Solução de brometo de hexadeciltrimetilamônio (1\%)}

Brometo de hexadeciltrimetilamônio

Água destilada

\subsubsection{Solução de pectina}

\section{Pectina citrica (ESKISA)}

Tampão acetato $\mathrm{pH}=4.0$
$1.0 \mathrm{~g}$

$100.0 \mathrm{ml}$

Suspendeu-se a pectina em metade do volume do tampão (item 3.4.7.) deixando-se a mistura sob agitação em agitador magnético por uma noite e, a seguir, completou-se o volume restante do tampảo para atingir um total de $100 \mathrm{ml}$.

Esta solução foi preparada na concentraçāo inicial de $0,63 \%$ de pectina para, quando misturada às amostras para medida de atividade, atingir a concentração final de 0.5\% (MAIORANO, 1990). 


\subsubsection{Solução albumina $50 \%$}

Uma clara de óvo foi colocada num becker e picotada vagarosamente com auxilio de uma tesoura durante uma hora. Filtrou-se e ao filtrado adicionou-se glicerina $(\mathrm{v} / \mathrm{v})$ e cristais de cânfora. A solução foi mantida em refrigerador a $4^{\circ} \mathrm{C}$.

\subsubsection{Solução tampão fosfato $\mathrm{pH} 6.9$ (0.2M)}

Solução A

$\mathrm{NaH}_{2} \mathrm{PO}_{4} \cdot \mathrm{H}_{2} \mathrm{O}$

Água destilada
$27.6 \mathrm{~g}$

$1000 \mathrm{ml}$

Solução B

$\mathrm{Na}_{2} \mathrm{HPO}_{4} \cdot \mathrm{H}_{2} \mathrm{O}$

Água destilada

$28,4 \mathrm{~g}$

$1000 \mathrm{ml}$

As soluçōes $A$ e $B$ foram conservadas no refrigerador, sendo o tampāo fosfato preparado no momento do uso, misturando-se $45 \mathrm{ml}$ da solução A e $55 \mathrm{ml}$ da solução $B$.

\subsubsection{Solução de giemsa}

$\begin{array}{ll}\text { Giemsa } & 1.0 \mathrm{~g} \\ \text { Glicerina } & 66.0 \mathrm{ml} \\ \text { Metanol } & 66,0 \mathrm{ml}\end{array}$

A Solução foi preparada pela adição de Giemsa em glicerina a $60^{\circ} \mathrm{C}$ e, após resfriamento, à temperatura ambiente, foi adicionado metanol.

Filtrou-se e conservou-se esta solução à temperatura ambiente. 


\subsubsection{Solução de desoxicolato de sódio $(10 \% \mathrm{p} / \mathrm{v})$}

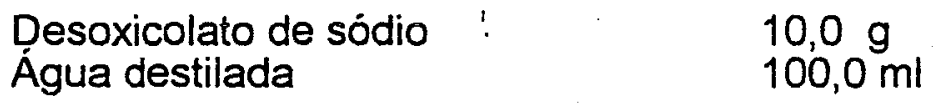

Esta solução foi sempre autoclavada e mantida em refrigerador.

\subsection{Isolamento dos fungos pectinolíticos}

\subsubsection{Isolados do solo}

Foram realizadas três coletas de solo no Estado de São Paulo, sendo uma na capital, de jardim doméstico, a segunda na região de Arthemis, próximo a Piracicaba, e a terceira coleta realizada em Colina. Em Piracicaba e Colina, as amostras de solo foram retiradas de propriedades particulares, em áreas destinadas ao plantio de laranjas. Estas amostras receberam a denominação de SP (solo de Piracicaba), SC (solo de Colina) e SJD (solo de jardim doméstico).

As amostras de solo foram coletadas da superfície numa profundidade máxima de $20 \mathrm{~cm}$, acondicionadas em sacos plásticos para transporte. $O$ isolamento dos fungos baseou-se em PARK et al., (1972), conforme o procedimento abaixo:

1. Tomaram-se $10 \mathrm{~g}$ de cada amostra coletada, as quais foram colocadas em Erlenmeyers de $250 \mathrm{ml}$ contendo $90 \mathrm{ml}$ de solução salina $(0.85 \%)$, agitando-se vigorosamente.

2. Após aproximadamente 1 hora de repouso, foram retiradas alíquotas de $1 \mathrm{ml}$ do líquido sobrenadante e colocadas em tubos de ensaio contendo $9 \mathrm{ml}$ de solução salina $0.85 \%$.

3. Posteriormente, procederam-se diluiçöes decimais e, a partir destas, efetuou-se o plaqueamento de $0,1 \mathrm{ml}$ por espalhamento com alça de Drigalski em placas de Petri, contendo cerca de $20 \mathrm{ml}$ do meio de Hankin 
(item 3.4.2. mod. 1) para obtenção de colônias monospóricas. As placas foram incubadas a $30^{\circ} \mathrm{C}$ por 5 dias. Este meio também foi utilizado para os posteriores isolamentos por ser um meio indicado para seleção de fungos produtores de enzimas pectinolíticas (HANKIN \& ANAGNOSTAKIS, 1975).

\subsubsection{Isolados de frutas}

Foram utilizadas frutas como laranja, maracujá e uva já em processo de deterioração. Uma amostra do fungo causador desse processo foi retirada com auxilio de uma alça de platina. Cada amostra foi repicada e isolada em placa de Petri, contendo meio de cultura de Hankin (item 4.4.2. Mod.1).

\subsubsection{Nomenclatura utilizada para os isolados encontrados}

Após obtenção de culturas puras, os isolados foram denominados de fungos pectinoliticos (FP) seguidas de números, com a finalidade de diferenciá-los (FP/01, FP/02, ....FP/101).

Dos 101 isolados, 84 linhagens são provenientes do solo (FP/01 ao FP/11; FP/27; FP/31 ao FP/101) e 17 foram advindas de frutas (FP/12 ao FP/26; FP/28 ao FP/30). As linhagens gentilmente cedidas para participarem da seleção quanto a atividade pectinolítica também receberam esta denominação sendo elas FP/102 a FP/108 descritas no item 3.1.2.

\subsection{Seleção dos isolados em placas (meio sólido)}

Entre as linhagens fúngicas isoladas neste trabalho $e$ as já existentes no laboratório de Microbiologia Industrial do Agrupamento de Biotecnologia da Divisão de Química - IPT, totalizou-se um número de 108 linhagens, as quais receberam a denominação prévia de fungos pectinolíticos (FP). 
Estes fungos foram avaliados quanto à produção de pectinases em placas contendo $20 \mathrm{ml}$ do meio de cultura (item 3.4.2. Mod.1) para visualização do halo de degradação da pectina, segundo o Método SemiQuantitativo estabelecido por HANKIN \& ANAGNOSTAKIS (1975), cada um dos isolados foi repicado pontualmente no centro de 3 placas de Petri, estas foram incubadas a $30^{\circ} \mathrm{C}$, por' 72 horas. Porém, exceções foram feitas para alguns fungos cujo crescimento foi mais rápido, necessitando assim de menor tempo de incubação.

Após o periodo de incubação, os diâmetros das colônias foram medidos e, em seguida, cobriu-se a superficie das placas com aproximadamente $5 \mathrm{ml}$ de solução aquosa de brometo de hexadeciltrimetilamônio a $1 \%$ (item 3.4.10), deixando-se em repouso por cerca de 20 a 30 minutos para que a reação substrato/solução pudesse ocorrer. Decorridos estes tempos, as placas foram esgotadas desta solução $e$ as medidas do diâmetro total (halo + colônia) foram efetuadas. Com este procedimento, pode-se observar um halo translúcido ao redor da colônia.

Isto ocorre porque a solução utilizada precipita a pectina intacta ainda presente no meio, tornando-o opaco, e a zona mais clara, denominada halo de degradação, denota ter havido hidrólise da pectina por ação das enzimas secretadas pelo fungo.

Esta atividade enzimática foi expressa conforme dois critérios de avaliação:

a) Índice de relação enzimática (FUNGARO, 1990), dado por:

$$
\begin{aligned}
& \text { I.R.E. = D/d } \\
& \text { onde: } \\
& D=\text { diâmetro do halo + colônia }(\mathrm{cm}) \\
& d=\text { diâmetro da colônia }(\mathrm{cm})
\end{aligned}
$$


b) Área total de degradação (VICENTE, 1989), dado por:

Área do halo $=\pi / 4 \cdot\left(D^{2}-d^{2}\right)$

onde:

$\mathrm{D}=$ diâmetro do halo + colônia $(\mathrm{cm})$

$\mathrm{d}=$ diâmetro da colônia $(\mathrm{cm})$.

Os valores obtidos para cada um dos fungos através desses dois critérios foram compilados.

\subsection{Seleção dos isolados em cultura submersa}

\subsubsection{Produção de inóculo}

A partir do crescimento dos fungos em tubos de ensaio contendo - meio ATCC-325 (item 3.4.1.), produziu-se uma suspensão com $8 \mathrm{ml}$ de solução aquosa com Tween $80(0.01 \%)$. Dessa suspensão, transferiu-se $1 \mathrm{ml}$ para erlenmeyer de $1000 \mathrm{ml}$ contendo $50 \mathrm{ml}$ de meio sólido (item 3.4.2. Mod.1), espalhando-se bem este volume na superficie do mesmo.

Uma vez inoculados, estes erlenmeyers foram incubados por cerca de 120 horas a $30^{\circ} \mathrm{C}$. Decorrido este periodo, os esporos desenvolvidos foram suspensos também com solução de Tween 80 (0.01\%), efetuando-se a contagem do número de esporos/ml da suspensão, em câmara de Neubauer, ao microscópio óptico.

A suspensão a ser incubada foi corrigida, quando necessário, para $10^{7}$ esporos $/ \mathrm{ml}$.

\subsubsection{Condições da fermentação}

Estes testes foram realizados em erlenmeyers de $250 \mathrm{ml}$ contendo $50 \mathrm{ml}$ de meio de cultura liquido, conforme item 3.4.2. Os 
erlenmeyers foram inoculados com $1 \mathrm{ml}$ da suspensāo obtida de acordo com item 3.7.1., com concentração de $10^{7}$ esporos $/ \mathrm{ml}$.

As culturas foram mantidas a $30^{\circ} \mathrm{C}$, sob agitação constante (200 ciclos por minuto), durante 72 horas. Após este período, as amostras foram filtradas em papel Whatman no 41 para retenção da massa celular e posterior medida de massa seca, procedendo-se às determinações de atividade enzimática e $\mathrm{pH}$ no filtrado.

\subsection{Cinética de crescimento e avaliação da atividade enzimática dos isolados selecionados}

Para estes testes foi adotado os mesmos procedimentos para produção de inóculo, bem como as mesmas condições de cultivo descritas nos itens 3.7.1. e 3.7.2., respectivamente. Entretanto, o ensaio foi acompanhado durante 120 horas, com amostragens a cada 24 horas, através das mesmas determinações mencionadas no item 3.7.2., ou seja, pH, massa seca e atividade enzimática.

\subsection{Acompanhamento analítico dos ensaios}

\subsubsection{Determinação do crescimento micelial}

A massa micelial foi separada por filtração, lavada com água destilada e seca em estufa a $60^{\circ} \mathrm{C}$, por 48 horas. O crescimento de cada isolado foi avaliado pelo peso seco da biomassa.

\subsubsection{Avaliação da atividade enzimática}

A atividade enzimática extracelular no complexo pectinolítico de cada fungo foi avaliada como atividade diminuidora da viscosidade, que corresponde principalmente à atividade das substâncias pectnoliticas que clivam ligações glicosídicas ao acaso, no interior da molécula do substrato, causando uma diminuição da viscosidade relativa da solução deste. 


\subsubsection{Método viscosimétrico}

A atividade diminuidora da viscosidade foi avaliada pelo método descrito por SAITO (1955) e modificada por MAIORANO (1990). Esta metodologia baseia-se na medida da redução de viscosidade de uma solução padronizada de pectina, conforme procedimento descrito a seguir.

\subsection{Procedimento}

a) a solução de pectina (item 3.4.11.) deve permanecer em banho-maria a 30( \pm $0.1)^{\circ} \mathrm{C}$, por cerca de 10 minutos, antes da análise ser iniciada.

b) em frasco de amostra, misturaram-se rapidamente $8 \mathrm{ml}$ da solução de pectina acima citada e $2 \mathrm{ml}$ da solução enzimática (filtrada de cada fungo), obtida conforme item 3.7.2., agitando-se vigorosamente. Utilizando-se um cronômetro digital, a contagem do tempo de reação foi iniciada a partir do instante em que a solução enzimática entrou em contato com o substrato (solução de pectina).

c) a seguir, a mistura de reação foi transferida imediatamente para um viscosimetro tipo Cannon-Fenske no 150 (conforme ASTM/D-446), e incubada em banho termostático ajustado a $30,0( \pm 0.1)^{\circ} \mathrm{C}$.

d) o tempo de escoamento da solução enzimática foi medido após exatamente 60 minutos, a partir do inicio da reação.

e) paralelamente, como branco, inativaram-se as enzimas contidas em uma alíquota da solução enzimática por aquecimento em banho-maria em ebulição por 30 minutos, repetindo-se as etapas de $a, b, c$ e $d$.

Para as leituras do tempo de escoamento sempre foi utilizado o mesmo viscosimetro, tanto para a solução enzimática como para o seu respectivo branco. Os viscosímetros foram calibrados com água destilada, nas mesmas condições de ensaio. 
Após medidos todos os tempos de escoamento, calculou-se a porcentagem de redução de viscosidade, através da equação l:

$$
\% \text { Red }=\frac{(\text { Teb }- \text { Tea })}{(\text { Tea }- \text { Teágua })} 100
$$

onde:

Tea $=$ Tempo de escoamento da amostra (segundos)

Teb $=$ Tempo de escoamento do branco (segundos)

Teágua $=$ Tempo de escoamento da água (segundos)

Uma unidade de atividade enzimática (1U), foi definida como sendo a quantidade de enzima necessária para diminuir em $50 \%$ a viscosidade inicial da solução do substrato, quando a $30^{\circ} \mathrm{C}$ por 60 minutos de reação.

\subsection{Cálculo da atividade enzimática}

Para a medida de atividade pectinolítica das enzimas secretadas pelos isolados foi necessário fazer uma curva de calibração imposta pelo método. MAIORANO et al. (1990) mencionam ainda que, quando se deseja comparar as atividades entre linhagens, deve-se utilizar da curva padrão da solução enzimática de cada uma das linhagens, para os posteriores cálculos de atividade enzimática. Neste caso, para as curvas durante a seleção, utilizouse de apenas dois pontos, dado o elevado número de isolados, calculando-se, posteriormente, a equação da reta: Para os ensaios cinéticos as curvas foram feitas com maior número de pontos, calculando-se a regressão linear.

Para exemplificar a maneira utilizada para o cálculo da atividade pectinolítica, tomou-se por base os ensaios de seleção. Procedeu-se diluições na solução enzimática de cada isolado, para que fosse possivel a obtenção de dois pontos com valores de porcentagens de redução acima e abaixo de $50 \%$. A partir do log da diluição efetuada para cada um dos pontos, associados aos seus respectivos valores de porcentagem de redução (\% Red), através da equação $\mathrm{I}$, obtiveram-se os pontos de uma reta. 
Os valores obtidos foram aplicados na equação II abaixo descrita, fornecendo o valor de concentração de enzima ([e]) necessária para redução de viscosidade em $50 \%$ que, por definição, representa o valor de uma unidade enzimática (1U):

$$
\begin{gathered}
\% \operatorname{Red}=a_{1}+b_{1} . \log [E] \\
\left(\frac{\left.\% \operatorname{Red}-a_{1}\right)}{b_{1}}\right) \\
{[E]=10}
\end{gathered}
$$

onde:

$a_{1}$ e $b_{1}=$ Coeficientes angular e linear encontrados a partir da equação da reta entre os dados de (\%) Red e Log da diluição empregada para os dois pontos indicados

$[E]=$ Concentração de enzima $(\% v / v)$

O valor assim obtido, indica qual dos filtrados enzimáticos teve maior atividade pois, quanto maior o valor da diluição necessária para se obter $50 \%$ de redução, maior será a quantidade de enzima presente no mesmo.

A partir do valor da $[E]$, pode-se fazer uma relação entre a concentração de enzima, unidade de atividade enzimática e porcentagem de redução da viscosidade; calcularam-se os valores de (\%Red) e [E] para duas unidades enzimáticas ( $2 U$ ) pela fórmula II.

Os valores de $[E]$ para (1U) e (2U), juntamente com seus respectivos valores de \%Red, foram utilizados para traçar uma nova curva, conforme a equaçāo III abaixo descrita:

$$
\begin{gathered}
\% \operatorname{Red}=\left(a_{2}+b_{2} \cdot \log U\right) \cdot d / v \\
\left(\frac{\left.\% \text { REd }-a_{2}\right)}{b_{2}}\right. \\
U=10 \cdot d / v
\end{gathered}
$$


onde:

$a_{2}$ e $b_{2}=$ Coeficientes linear e angular encontrados a partir da equação da reta entre os dois pontos de $\log (1 U)$ e $\log (2 U)$ e suas respectivas \%Red

$\mathrm{U}=$ Unidade de atividade enzimática $\mathrm{U} / \mathrm{ml}$

$d$ = Diluição efetuada no extrato enzimático referente ao valor de \%Red utilizado

$v=$ Volume de solução enzimática utilizada na análise $(2 \mathrm{ml})$

Através desta equação obteve-se o valor de unidade enzimática pectinolítica expressa em unidade por $\mathrm{ml}(\mathrm{U} / \mathrm{ml})$.

\subsection{Caracterização dos isolados selecionados}

\subsubsection{Classificação dos isolados}

Os isolados mais promissores, selecionados em cultura submersa, quanto à produção de pectinases, foram encaminhados ao Departamento de Micologia do Centro de Ciências Biológicas da Universidade Federal de Pernambuco-Recife, onde foram classificados pelos seguintes professores: Dra. Elza Áurea de Luna Alves Lima, Dra. Maria José dos Santos Fernandes e Dra. Maria Auxiliadora de Queiroz Cavalcanti.

\subsubsection{Coloração de núcleos de conidio - técnica citológica} (TANAKA et al., 1979, modificado por VEGA, 1990)

Nos isolados selecionados foram realizadas observações citológicas através da coloraçāo de núcleos (com ligeiras modificações na técnica citológica), conforme procedimentos descritos a seguir, estimando-se o número de núcleos por esporos. Para estes estudos os isolados foram previamente cultivados em meio ATCC - 325 (item 3.4.1) durante 4 dias a $30^{\circ} \mathrm{C}$. 


\subsubsection{Preparo da lâmina}

Os esporos dos referidos isolados foram aderidos a lamínulas previamente pinceladas com albumina $50 \%$ e levemente secas em um bico de Bunsen. Posteriormente, foi efetuada a fixação deste material com metanol absoluto durante 15 minutos. Após a fixação, mergulharam-se rapidamente estas laminulas em uma solução de hipoclorito $5 \%$ secando-se à temperatura ambiente. Depois de secas, as lamínulas foram colocadas para hidrólise ácida em solução $\mathrm{HCl} .1 \mathrm{~N}$ em temperatura ambiente e $60^{\circ} \mathrm{C}$ por 7 minutos e 20 minutos, respectivamente. Lavou-se por três vezes consecutivas em água destilada e uma vez em tampão fosfato $\mathrm{pH} 6,9$; os esporos foram corados por imersão em solução corante Giemsa, diluida de 1 para 9 com tampão fosfato pH 6,9; durante 30 minutos.

O excesso de corante foi retirado por lavagem com o mesmo tampão. A seguir, procedeu-se a montagem provisória em lâminas, vedando as bordas das lamínulas com esmalte incolor, procurando evitar bolhas de ar entre lâmina e lamínula.

Para observaçōes microscópicas foi utilizado o microscópio marca Riechert - Modelo 120 - Série 100 23-7, associado ao sistema fotomicrográfico de mesma marca, quando necessário.

\subsubsection{Determinação do número de núcleos por conidio}

Conídios com o mesmo tempo de crescimento foram observados ao microscópio óptico e determinada a porcentagem média de núcleos por conídios. Para tanto, foram empregados 500 conídios para cada isolado.

\subsection{Preservação dos fungos pectinolíticos}

\subsubsection{Preservação por liofilização}

As linhagens de fungos produtores de pectinases foram preservadas por liofilizaçăo utilizando-se um processo no qual dissociou-se a 
fase de congelamento da fase de secagem das amostras. As linhagens produtoras de pectinases, inicialmente liofilizadas, foram aquelas cedidas por laboratórios de pesquisa, listadas no item 3.1.2. Quanto as linhagens isoladas, foram mantidas pelo processo de liofilização somente aquelas selecionadas como mais promissoras: FP/21, FP/42, FP/46,FP/69, FP/76 e FP/83.

Para liofilização foi empregado o método descrito por KIRSOP (1984), conforme demonstrado através da Figura 7, a seguir. As linhagens foram cultivadas no meio descrito em materiais e métodos (item 3.4.1), durante 5 dias a $30^{\circ} \mathrm{C}$. Dados de literatura indicaram como protetor para a liofilização de fungos uma solução de leite desnatado a $10 \%$ e inositol a $5 \%$ (SILVA, 1990).

Preparou-se uma suspensão adicionando-se $5 \mathrm{ml}$ desta solução protetora à cultura, agitando-se suavemente para remover os esporos do meio. Aliquotas de $0,2 \mathrm{ml}$ dessa suspensão foram distribuidas em ampolas esterilizadas e submetidas a um congelamento lento $\left(1^{\circ} \mathrm{C} / \mathrm{min}\right)$ em "Shell freezer" Labconco mod. 75250 até $-50^{\circ} \mathrm{C}$, permanecendo a esta temperatura por mais duas horas após o congelamento.

A liofilização foi então realizada em "Tray-dryer" Labconco mod. 75150 durante cerca de 18 horas a $-20^{\circ} \mathrm{C}$ e $5 \mathrm{~mm}$ de $\mathrm{Hg}$, quando as ampolas foram transferidas para o "manifold" do aparelho para fechamento a vácuo utilizando-se maçarico.

Foram feitas determinações de viabilidade da suspensão de esporos antes do congelamento, após a liofilização e armazenamento. Para isto, semeou-se, por espalhamento com alça de Drigalski, $0,1 \mathrm{ml}$ de diluiçōes apropriadas de cada amostra em placas de Petri contendo meio de cultura (item 3.4.1), em triplicata.

Após incubação a $30^{\circ} \mathrm{C}$, procedeu-se a contagem de colônias ( 24 e $48 \mathrm{~h}$ ), exprimindo-se o resultado em unidades formadoras de colônias por mililitro da amostra (UFC/ml). As ampolas foram armazenadas em refrigerador doméstico, sendo avaliadas periodicamente. 


\section{ESOUEMA PARA PROCESSO DE LOFILIZACĀO}

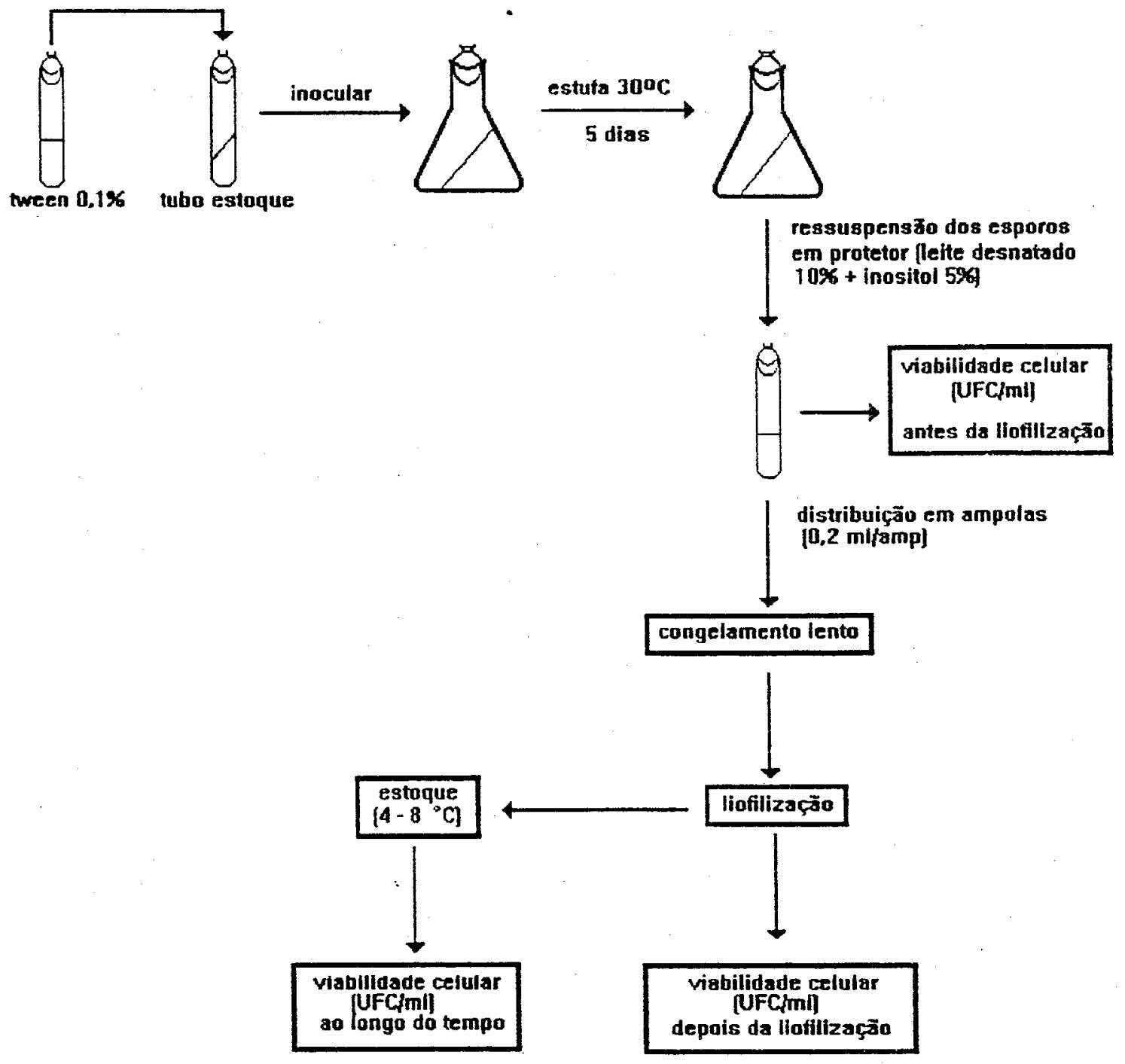

Figura 7. Esquema para o processo de liofilização. 
Cada linhagem fúngica foi catalogada no Banco de Microrganismos do Laboratório de Microbiologia Industrial do Agrupamento de Biotecnologia (LMI/AB) do IPT, estando suas caracteristicas descritas em planilhas apropriadas.

\subsubsection{Preservação em nitrogênio líquido}

As culturas foram obtidas em meio ATCC 325 sólido, $30^{\circ} \mathrm{C}$ após cultivo por cinco dias.

Empregou-se uma solução de glicerol a $10 \%$ como protetor contra danos resultantes do congelamento (KIRSOP, 1984). Os esporos foram suspensos na solução protetora e aliquotas de $0,05 \mathrm{ml}$ da suspensão obtida foram distribuidos em tubos de plástico ( $30 \mathrm{~mm}$ de altura $\times 3 \mathrm{~mm}$ de diâmetro) selados em uma das extremidades, conforme descrito por KIRSOP \& HENRY (1984).

Os canudinhos foram selados, acondicionados em frascos de polipropileno com tampa rosqueável e submetidos ao congelamento, baixandose $1^{\circ} \mathrm{C} / \mathrm{mm}$ ate $-50^{\circ} \mathrm{C}$. Após $2 \mathrm{~h}$ a $-50^{\circ} \mathrm{C}$ passaram a ser estocados imersos em nitrogênio liquido em "containers" apropriados.

A viabilidade celular foi avaliada antes e depois do congelamento, efetuando-se acompanhamento periódico a fim de se determinar a eficiência deste método para as espécies estudadas. Para recuperação e contagem, as amostras foram descongeladas rapidamente por imersão e agitação em banhomaria a $37^{\circ} \mathrm{C}$, procedendo-se como descrito no item anterior.

\subsection{Sobrevivência à luz ultravioleta}

Suspensão de conídios da linhagem selvagem FP/83 em tween 80 foi observada ao microscópio com auxilio de uma câmara de Neubauer, para se estimar o número de conídios por mililitro. Esta solução foi diluída em solução salina para concentração final de $1 \times 10^{6}$ conídios por $\mathrm{ml}$, colocada em placa de Petri esterilizada, e irradiada com luz ultravioleta (marca MINERALIGHT - mod. R 52 - ULTRA-VIOLET Prod. INC. USA - 60 Amps.), em diferentes tempos de exposição a uma distância de $12,5 \mathrm{~cm}$ da lâmpada. 
A seguir, após cada periodo de irradiação, uma alíquota de $1 \mathrm{ml}$ foi retirada da placa. Essas aliquotas, assim como as do controle, foram convenientemente diluidas em śolução salina $0,85 \%$ e $0,1 \mathrm{ml}$ de cada solução foi semeado em placas contendo meio completo (item 3.4.4) e $0,1 \%$ de desoxicolato de sódio, e incubados a $30^{\circ} \mathrm{C}$ em ausência de luz por 5 dias.

Após este período, as colônias isoladas foram contadas e procedeu-se o cálculo da curva de sobrevivência, tomando-se o número de colônias obtidas no tempo $0^{\circ}$ (zero) minutos como $100 \%$ de sobrevivência. Foi estimado deste modo, o tempo de irradiação que permite $5 \%$ de sobrevivência para a linhagem.

\subsubsection{Isolamento de mutantes morfológicos}

Após a determinação do tempo de irradiação que permitisse a sobrevivência de $5 \%$ dos conídios, procedeu-se nova irradiação neste tempo, do mesmo modo conforme descrito no item 3.9.5.. A suspensão irradiada foi diluida seriadamente. De cada diluição semeou-se 0,1 ml por placa de Petri contendo meio completo (item 3.4.4) e incubou-se a $30^{\circ} \mathrm{C}$ por 5 dias. As colônias com alterações morfológicas encontradas foram isoladas por réplica em meio completo e utilizadas nos testes.

\subsubsection{Teste de reversão}

As linhagens mutantes foram repicadas por um ponto no centro de 10 placas de Petri contendo meio estoque ATCC-325 (item 3.4.1). Nestas procurou-se observar alterações morfológicas e presença de setores.

\subsection{Testes posteriores}

Os mutantes foram selecionados em cultura submersa, conforme descrição no item 3.7., sendo sua produção enzimática avaliada segundo o item 3.8., o que permitiu comparar o mutante mais promissor em relação a seu parental. 


\subsection{Análises estatísticas}

Os resultados obtidos foram submetidos a uma análise de variância utilizando-se um delineamento inteiramente casualizado. Para a correlação entre as variáveis obtidas na seleçāo em meio sólido e líquido foi utilizado o Coeficiente de Correlação Simples. Também foram obtidos os seguintes Índices de Seleção:

- IC (Índice Clássico), obtidos pelo método clássico de SMITH (1936);

- $\mathrm{IH}^{*}$ (Índice das Herdabilidades) e;

- IUTMS (produto das variáveis: unidade enzimática e massa celular seca obtidas em meio de cultura líquida)**.

* Indice proposto por SOUZA JR. (não publicado), comunicação pessoal feita à FERNANDES, J. S. C.

* Índice proposto por FERNANDES, J. S. C., comunicação pessoal feita à LOPES-SHIKIDA, S. A. R. 


\section{RESULTADOS E DISCUSSÃO}

\subsection{Isolamento dos fungos}

O primeiro passo no desenvolvimento e melhoramento de um processo de produção industrial para enzimas pectinoliticas é a busca por linhagens produtivas (ROMBOUTS \& PILNIK, 1980). Nesse sentido, foram efetuadas coletas de solo e fontes naturais onde procedeu-se $\mathrm{o}$ isolamento $\mathrm{e}$ posterior seleção entre os isolados. Para a detecção daqueles mais promissores na produção de enzimas pectinolíticas, lançou-se mão do método de seleção em placas (meio sólido) e posteriormente da seleção em cultura submersa.

No isolamento inicial dos fungos utilizou-se o meio cultura de HANKIN-Mod 1 item (3.4.2.). Tal meio de cultivo foi adotado por ser indicado para seleção de fungos pectinolíticos (HANKIN \& ANAGNOSTAKIS, 1975). As colônias morfológicamente distintas, crescidas neste meio, foram transferidas para um novo meio para obtenção de colônias monospóricas puras. Como resultado dos isolamentos de solo e fontes naturais, foram obtidos um total de 102 linhagens fúngicas potencialmente pectinolíticas. Estas encontram-se discriminadas na Tabela 2.

Entre os isolados purificados observou-se uma grande variabilidade morfológica, indicando a obtenção de diversos gêneros, ocorrendo com maior frequència representantes dos gêneros Aspergillus, Penicillium e Trichoderma. As 102 linhagens obtidas sāo potencialmente pectinoliticas, pois foram isoladas em meio seletivo. Tais linhagens foram submetidas a um processo de seleção com a finalidade de se obter indicações daquelas mais promissoras. 
Tabela 2. Procedência dos isolados obtidos em diferentes coletas de solos e fontes naturais

\begin{tabular}{|c|c|c|}
\hline Local de Origem & Fonte & Isolados \\
\hline $\begin{array}{c}\text { SPV } \\
\text { Sítio Paredão Vermelho } \\
\text { Arthemis/S.P. }\end{array}$ & Solo & $\begin{array}{l}F P / 01 \text { - FP/02 - FP/03 - FP/04 - FP/05 - } \\
\text { FP/06 - FP/07 - FP/08 - FP/09 - FP/10 - } \\
\text { FP/11 - FP/27 - FP/31 - FP/32 - FP/33 - } \\
\text { FP/34 - FP/35 - FP/36 - FP/37 - FP/38 - } \\
\text { FP/39 - FP/40 - FP/41 - FP/42 - FP/43 - } \\
\text { FP/44 - FP/45 - FP/46 - FP/47 - FP/48 - } \\
\text { FP/49 - FP/50 - FP/51 - FP/52 - FP/53 - } \\
\text { FP/54 - FP/55 - FP/56 - FP/57 - FP/58 - } \\
\text { FP/59 - FP/60 - FP/61 - FP/62 - FP/63 - } \\
\text { FP/64 - FP/65 - FP/66 - FP/67 - FP/68 - } \\
\text { FP/71 - FP/72 - FP/73 - FP/74 - FP/74 - } \\
\text { FP/88 - FP/89 - FP/90 - }\end{array}$ \\
\hline $\begin{array}{c}\text { FMB } \\
\text { Fazenda Monte Belo } \\
\text { Colina/S.P. }\end{array}$ & Solo & $\begin{array}{l}\text { FP/69 - FP/70 - FP/77 - FP/78 - FP/79 - } \\
\text { FP/80 - FP/81 - FP/82 - FP/83 - FP/84 - } \\
\text { FP/85 - FP/86 - FP/87 - FP/93 - FP/94 - } \\
\text { FP/95 - FP/96 - FP/97 - FP/98 - FP/99 - } \\
\text { FP/100 - FP/101 }\end{array}$ \\
\hline \multirow[t]{2}{*}{$\begin{array}{l}\text { Jardim Doméstico } \\
\text { São Paulo/S.P. }\end{array}$} & Solo & $F P / 75$ - FP/76 - FP/91 - FP/92 - \\
\hline & Uva & $\begin{array}{l}F P / 12 \text { - FP/13 - FP/14 - FP/15 - FP/16 - } \\
F P / 17\end{array}$ \\
\hline \multirow[t]{2}{*}{$\begin{array}{c}\text { Fontes Naturais } \\
\text { (Frutas em Deterioração) }\end{array}$} & Maracujá & $\begin{array}{l}F P / 18 \text { - FP/19 - FP/20 - FP/21 - FP/23 - } \\
F P / 24 \text { - FP/25 - FP/26 }\end{array}$ \\
\hline & Laranja & $F P / 22$ - FP/28 - FP/29 - FP/30 - \\
\hline
\end{tabular}

\subsection{Seleção dos isolados quanto a produção de enzimas pécticas especificas}

Considerando o mercado para pectinases para uso em processos (US $\$ 165$ milhöes/ano), é surpreendente que existam poucos exemplos onde a produção tenha sido otimizada pelo isolamento de linhagens de fungos e bactérias hiper produtoras (FORGART \& KELLY, 1983). 
Segundo DURRANDS \& COOPER (1988), isto talvez ocorra devido aos meios de seleção, ainda serem deficientes, pois muitas vezes se utilizam de altos niveis de fonte de energia, podendo com isto causar o efeito de repressão catabólica. Outro ponto importante é que frequentemente estes meios não são tamponados $e$, portanto, ficam sujeitos a pH flutuante durante 0 cultivo. Assim sendo, ressaltam a importância em superar estas deficiências, além de cautela na interpretação dos resultados.

\subsubsection{Seleção em placas (meio sólido)}

As técnicas de difusão em ágar são empregadas para detecção da atividade enzimática (SCRIBAN, 1985), tendo sido utilizada inicialmente no presente trabalho. A avaliação da produçảo de exoenzimas em placas consiste na hidrólise da pectina presente no meio, permitindo avaliar qualitativamente a produção de enzimas extracelulares através da visualização de halo no meio. Esta produção tem sido estimada pelo índice de relação enzimática, que consiste na razão da medida do diâmetro total (colônia + halo) pelo diâmetro das colônias (BERTOLINI, 1987; ROUMAS, 1988; VALADARES, 1989). Contudo, VICENTE (1989) considerou que, para melhor expressar a capacidade de degradação dos fungos, deve-se avaliar a área total de degradação e a área de crescimento da colônia, conforme fórmula apresentada no item (3.6.). Tal procedimento forneceu-lhe uma estimativa mais precisa em relação ao índice enzimático.

Tendo em vista os diferentes pontos apresentados, as linhagens isoladas neste trabalho, bem como aquelas adyindas de coleções de cultura, foram selecionadas quanto à capacidade hidrolítica pelo teste semi quantitativo em placas baseado em HANKIN \& ANAGNOSTAKIS (1975) conforme item (3.6.), e foram avaliados segundo os dois critérios aqui apresentados.

Os resultados obtidos (conforme Tabela 3), foram comparados com a linhagem FP/107 de Aspergillus orzyae, empregada como referência neste caso. A linhagem FP/107 foi utilizada por MAIORANO (1990) em estudos de produção de pectinase, por fermentação em estado semi-sólido e submerso, a qual apresentou resultados reprodutiveis alcançando uma produtividade de 
10.74 U/gms.h em pH 3.6 no tempo de 48 horas, e $13,26 \mathrm{U} / \mathrm{ml}$ em $\mathrm{pH}$ semelhante no tempo de 96 horas, respectivamente.

TABELA 3: Seleção dos isolados selvagens pelo método semiquantitativo (meio sólido), utilizando-se dois critérios de avaliação: Indíce de Relação Enzimática (IRE) e Área de Degradação Enzimática (ADE). Os dados representam a média de 3 repetições, no tempo de 72 horas, as medidas em diâmetro $(\varnothing)$ são dadas em $\mathrm{cm}$.

\begin{tabular}{|c|c|c|c|c|c|}
\hline Linhagem & $\varnothing$ da colónia $(\mathrm{cm})$ & $\oslash$ do halo $(\mathrm{cm})$ & & $\begin{array}{c}\text { Indice de Relaçâo } \\
\text { Enz. }\end{array}$ & $\begin{array}{c}\text { Área de Degr. Enz. } \\
\left(\mathrm{cm}^{2}\right)\end{array}$ \\
\hline FP/1 & 2,46 & 3,60 & & 1,46 & 5,40 \\
\hline $\mathrm{FP} / 2$ & 0,60 & 1,90 & & $\underline{3.17}$ & 2,55 \\
\hline $\mathrm{FP} / 3$ & 2,63 & 3,47 & & 1,32 & 3,98 \\
\hline FP/4 & 1,63 & 1,73 & & 1,06 & 026 \\
\hline FP/5 & 3,20 & 3,20 & & 1,00 & 0 \\
\hline $\mathrm{FP} / 6$ & 2,00 & 3,87 & & 1,87 & 8,39 \\
\hline FP $\pi$ & 1,57 & 1,70 & & 1,08 & 0,35 \\
\hline FP/8 & 1,43 & 1,80 & & 1,25 & 0,92 \\
\hline FP/9 & 1,27 & 1.27 & & 1,00 & 0 \\
\hline $\mathrm{FP} / 10$ & 0,53 & 0,53 & & 1,00 & 0 \\
\hline FP/11 & 1,47 & 2,13 & & 1,45 & 1,88 \\
\hline $\mathrm{FP} / 12$ & 6,30 & 7.17 & & 1,14 & 8,14 \\
\hline$F P / 13$ & 4,10 & 5,10 & & 1,24 & 7.25 \\
\hline$F P / 14$ & 2,73 & 4,20 & & 1,55 & 7,96 \\
\hline FP/15 & 3,90 & 4,97 & & 1,27 & 7,43 \\
\hline$F P / 16$ & 4,30 & 4,30 & & 1,00 & 0 \\
\hline FP/17 & 4,17 & 5.13 & & 1,23 & 7,05 \\
\hline FP/18 & 5,43 & 5,70 & & 1.04 & 2,33 \\
\hline FP/19 & 4,17 & 4,27 & & 1,02 & 0,66 \\
\hline$F P / 20$ & 5,53 & 6.13 & & 1,11 & 5,44 \\
\hline FP/21 & 1,20 & 1,93 & & 1,63 & 1.79 \\
\hline FP/22 & 1,47 & 2,17 & $\sigma$ & 1,48 & 2,00 \\
\hline $\mathrm{FP} / 23$ & 2,90 & 3,63 & & 1,25 & 3,75 \\
\hline$F P / 24$ & 4,80 & 5,86 & & 1,22 & 8,91 \\
\hline$F P / 25$ & 4.70 & 5,00 & & 1,06 & 2,29 \\
\hline FP/26 & 2.23 & 3,20 & & 1,42 & 4,13 \\
\hline $\mathrm{FP} / 27$ & 0,63 & 2,33 & & 3,68 & 3,99 \\
\hline$F P / 28$ & 4,30 & 4,50 & & 1,04 & 1,38 \\
\hline FP/29 & 3,33 & 3.57 & & 1,07 & 1.26 \\
\hline FP/30 & 5.23 & 6,07 & & 1,16 & 7,37 \\
\hline FP/31 & 3.10 & 4,10 & & 1,32 & 5,65 \\
\hline FP/32 & 4,60 & 5.63 & & 1,23 & 8,31 \\
\hline FP/33 & $4, \pi 7$ & 5,67 & & 1,19 & 7.37 \\
\hline FP/34 & 4,27 & 5,23 & & 1.23 & $\begin{array}{c}7.19 \\
\text { continua... }\end{array}$ \\
\hline
\end{tabular}


continuaçăo tabela 3

\begin{tabular}{|c|c|c|c|c|}
\hline Linhagem & $\varnothing$ da colonia $(\mathrm{cm})$ & $\varnothing$ do halo $(\mathrm{cm})$ & $\begin{array}{c}\text { Indice de Relaçăo } \\
\text { Enz. }\end{array}$ & $\begin{array}{c}\text { Área de Degr. } \\
\text { Enz. }\left(\mathrm{cm}^{2}\right)\end{array}$ \\
\hline FP/35 & 4,27 & 4,63 & 1,08 & 2,55 \\
\hline FP/36 & 1,00 & 2.13 & $\underline{2.15}$ & 2,80 \\
\hline FP/37 & 1,83 & 1,83 & 1,00 & 0 \\
\hline FP/38 & 2,63 & 4,17 & 1,58 & 8,22 \\
\hline FP/39 & 3,30 & 4,20 & 1,27 & 5,28 \\
\hline $\mathrm{FP} / 40$ & 4,27 & 5,13 & 1,21 & 6,35 \\
\hline $\mathrm{FP} / 41$ & 4,73 & 5,67 & 1,20 & 0 \\
\hline FP/42 & 4,97 & 5,90 & 1,19 & 7,97 \\
\hline$F P / 43$ & 5,37 & 6,17 & 1.15 & 7,25 \\
\hline $\mathrm{FP} / 44$ & 4,70 & 5,67 & 1,20 & 7.86 \\
\hline$F P / 45$ & 3,20 & 4,17 & 1,30 & 5,59 \\
\hline FP/46 & 3,47 & 4,47 & 1,29 & 6,22 \\
\hline FP/47 & 4,80 & 5,83 & 1,21 & 8,62 \\
\hline $\mathrm{FP} / 48$ & 4,70 & 5.77 & 1,23 & 8,74 \\
\hline$F P / 49$ & 4,40 & 5,53 & 1,26 & 8,84 \\
\hline FP/50 & 4,00 & 4,40 & 1,10 & 2,62 \\
\hline FP/51 & 3,50 & 3,80 & 1,09 & 1,66 \\
\hline FP/52 & 4,43 & 4,80 & 1,08 & 2,65 \\
\hline $\mathrm{FP} / 53$ & 1,43 & 1,97 & 1,37 & 1,35 \\
\hline FP/54 & 3,20 & 3,50 & 1,59 & 5,85 \\
\hline FP/55 & 1,63 & 2,20 & 1,34 & 1,71 \\
\hline FP/56 & 5,43 & 2,97 & 1,11 & 4,59 \\
\hline FP/57 & 1,97 & 2,07 & 1.05 & 0,32 \\
\hline FP/58 & 1,33 & 1,90 & 1,43 & 1.44 \\
\hline FP/59 & 3,10 & 4,23 & 1,36 & 6,53 \\
\hline FP/60 & 3,57 & 4,53 & 1,27 & 6,17 \\
\hline FP/61 & 1,33 & 2,47 & 1,86 & 3,38 \\
\hline FP/62 & 2,50 & 3,17 & 1,27 & 3,30 \\
\hline$F P / 63$ & 2,40 & 2,70 & 1,14 & 1,32 \\
\hline $\mathrm{FP} / 64$ & 0,83 & 2,90 & 3,49 & 6,08 \\
\hline FP/65 & 1.43 & 2.73 & 1,93 & 3,03 \\
\hline FP/66 & 1,53 & 3,00 & 1,96 & 5.23 \\
\hline FP/67 & 2,33 & 3.43 & 1.47 & 4,98 \\
\hline FP/68 & 1,17 & 1.17 & 1,00 & 0 \\
\hline FP/69 & 4,17 & 4,90 & 1,18 & 5,22 \\
\hline FP 70 & 2,23 & 3,33 & 1,49 & 4,81 \\
\hline FPTI1 & 4,50 & 5,23 & 3,49 & 5,62 \\
\hline FP $/ 72$ & 4,27 & 4,70 & 1,10 & 3.06 \\
\hline $\mathrm{FP} / 73$ & 2.43 & 3,77 & 1,51 & 5,92 \\
\hline FP $/ 74$ & 2,50 & $2, \pi 7$ & 1,10 & 1,12 \\
\hline$F P / 75$ & 5,96 & 6,07 & 1,02 & 0,95 \\
\hline FP 76 & 5,40 & 6.10 & 1,14 & 6,61 \\
\hline $\mathrm{FP} / 77$ & 5,37 & 5.37 & $1, \infty 0$ & 0 \\
\hline $\mathrm{FP} / 78$ & 5,20 & 6,33 & 1,22 & 10,33 \\
\hline FP $/ 79$ & 5,00 & $5, \pi$ & 1,15 & 6,49 \\
\hline FP/80 & 5.00 & 5.83 & 1,17 & 7.09 \\
\hline FP/81 & 4,90 & 5,70 & 1,16 & $\begin{array}{c}6,66 \\
\text { continua, }\end{array}$ \\
\hline
\end{tabular}


continuaça tabela 3

\begin{tabular}{|c|c|c|c|c|}
\hline Linhagem & $\varnothing$ da colönia $(\mathrm{cm})$ & $\oslash$ do halo $(\mathrm{cm})$ & $\begin{array}{c}\text { Indice de Relaçáo } \\
\text { Enz. }\end{array}$ & $\begin{array}{c}\text { Área de Degr. Enz. } \\
\left(\mathrm{cm}^{2}\right)\end{array}$ \\
\hline FP/82 & 0,77 & 1,33 & 1,66 & 1,20 \\
\hline FP/83 & 6,13 & 6,13 & 1,00 & 0 \\
\hline FP/84 & 5,47 & 6,23 & 1,14 & 7,04 \\
\hline FP/85 & 0,90 & 1,03 & 1,08 & 0.20 \\
\hline FP/86 & 4,53 & 4,90 & 1,08 & 2,71 \\
\hline FP/87 & 5,97 & 6,57 & 1.10 & 5,88 \\
\hline FP/88 & 3,90 & 4,90 & 1,26 & 6,91 \\
\hline FP/89 & 1,03 & 2,00 & 1.94 & 2,30 \\
\hline FP/90 & 6,90 & 7,60 & 1,10 & 7,98 \\
\hline FP/91 & 5,10 & 5,37 & 1,05 & 2,18 \\
\hline FP/92 & 4,73 & 4,73 & 1,00 & 0 \\
\hline FP/93 & 1,57 & 2,87 & 1,84 & 4,51 \\
\hline FP/94 & 0.67 & 1,40 & 2,05 & 1,45 \\
\hline FP/95 & 0,93 & 1,87 & 2,00 & 2,08 \\
\hline FP/96 & 4,47 & 4,87 & 1,09 & 2,96 \\
\hline FP/97 & 3.87 & 5,00 & 1,29 & 7,89 \\
\hline FP/98 & 3,30 & 3,50 & 1,06 & 1,06 \\
\hline FP/99 & 0,47 & 2,27 & $\underline{4,89}$ & 5,31 \\
\hline$F P / 100$ & 1,30 & 1,63 & 1,25 & 0,81 \\
\hline FP/101 & 3,67 & 3,87 & 1,05 & 1,18 \\
\hline FP/102 & 3,57 & 5,43 & 1,53 & 13,35 \\
\hline FP/103 & 3,67 & 5,33 & 1,46 & $11, \pi$ \\
\hline FP/104 & 4,67 & 5,83 & 1,25 & 9,63 \\
\hline FP/10S & 3,20 & 5,03 & 1,57 & 11,85 \\
\hline FP/106 & 3,77 & 5,30 & 1,41 & 10,92 \\
\hline FP/107 (Padrao) & 3,27 & 3,53 & 1,08 & 1,41 \\
\hline$F P / 108$ & 4.07 & 4.07 & 1.00 & 0 \\
\hline
\end{tabular}

$\mathrm{Na}$ Tabela 3 observa-se, nas duas últimas colunas, os 5 melhores resultados obtidos, segundo os dois critérios de avaliação, quando comparados com a linhagem padrão $\mathrm{FP} / 107$. Estes valores encontram-se sublinhados, sendo FP/99; FP/27; FP/64; FP/O2 e FP/36 os melhores quanto ao índice de Relação Enzimática (IRE) apresentando valores como 4,89; 3,68; 3,53, 3,17 e 2,15, respectivamente. Aqueles com os maiores valores de Àrea de Degradação Enzimática (ADE) foram FP/102; FP/105; FP/103; FP/106 e FP/78, com valores de 13,$35 ; 11,85 ; 11,77 ; 10,92$ e 10,33, respectivamente.

$\mathrm{Na}$ avaliaçäo, utilizando o índice de Relaçāo Enzimática como critério de seleção, observou-se que $75 \%$ dos isolados apresentaram valores superiores a 1.08, valor obtido pela linhagem padrão FP/107 usada como padrão. Através do critério de avaliação dado pela Àrea de Degradação 
Enzimática obteve-se $73 \%$ dos isolados apresentando valores superiores a 1.41 , valor este obtido pela linhagem padrão FP/107. Embora os valores em percentagem estejam próximos, a correlação estimada entre os dois critérios de seleção em meio sólido foi de $0,32^{*}(P<0,05)$, indicando portanto; uma correlação muito baixa, o que significa que os melhores resultados obtidos por um apontam linhagens diferentes daquelas indicadas pelo outro critério.

$\mathrm{Na}$ Tabela 3 pode-se observar ainda que as linhagens apresentado crescimento reduzido, ou seja, com diâmetro de colônia inferior a $2 \mathrm{~cm}$, representando $27 \%$ do total de isolados, são as linhagens que em geral tiveram valores de área de degradação muito baixos. Entretanto, entre estas, linhagens encontram-se 4 daquelas indicadas como mais promissoras pelo indice de Relação Enzimática.

Tais distorções nos resultados advêm provavelmente das diferentes interpretaçōes que os dois critérios impōem, pois considerando que uma colônia de tamanho maior pode produzir, mesmo que o diâmetro de seu halo seja menor, maior área degradada de pectina em relação a uma colônia menor, que expresse um halo considerável. Poder-se-ia dizer que talvez o critério de avaliação por área degradada fosse o mais apropriado, como sugere VICENTE (1989). Entretanto, uma colônia pequena que apresente um halo surpreendente, pode indicar que a linhagem tem grande capacidade de secreçảo ou que a potência das enzimas liberadas seja superior a outras que expressem halos menores.

Contudo, em atividades enzimáticas alteradas, podem estar envolvidos mecanismos de síntese elou excreção. Segundo MONOSCO (1987), colônias pequenas, porém com massa micelial densa, compactadas, poderiam apresentar maior número de núcleos por unidade de área, resultando em uma produção enzimática maior, proporcionalmente ao tamanho da colônia. Em Aspergillus nidulans, o referido autor relatou ainda que linhagens de menor crescimento apresentaram os maiores índices enzimáticos para lipase, amilase e protease. VALADARES (1989) relatou que recombinantes de Metarhizium anisopliae com crescimento reduzido, apresentavam maiores médias de índice amilolítico. 
Assim, os resultados obtidos e sumarizados na tabela 3 foram submetidos a uma análise de variância (ítem 3.14), onde se analisou as caracteristicas observadas noś dois critérios de avaliação, ou seja, Índice de Relação Enzimática (IRE) e Área de Degradação Enzimática (ADE), conforme denominados no item 3.6. As tabelas 4 e 5 apresentam, respectivamente, o quadro da análise de variância bem como o teste Tukey para as médias de cada caráter utilizado na avaliação desse experimento.

Através das análises de variância (tabelas 4 e 5), observa-se a existência de uma ampla variabilidade genética entre as linhagens para os dois parâmetros analisados (IRE e ADE), sendo $F=87,01^{* *}$ e 9,74** (significativos a $1 \%$ ), respectivamente. Esta variabilidade foi confirmada pelas Herdabilidades no sentido amplo, ou grau de determinação genético, que é dado pela proporção da variância fenotípica $\left(\sigma^{2} \mathrm{~F}\right.$ ), determinada pela variância genética ( $\sigma$ ${ }^{2} \mathrm{G}$ ). Tais valores, para as caracteristicas avaliadas (IRE e ADE), foram muito altas, sendo $96,6 \%$ e $74,5 \%$ para cada caráter, respectivamente. Isso significa que existe uma variabilidade genética muito grande para estas características e que se a seleção fosse feita para alguma delas, o progresso esperado com a seleção seria muito grande.

Desse modo, na hipótese de que a razão entre o diâmetro do halo pelo diâmetro da colônia denominado de índice (IRE), e a área da colônia pela área do halo denominado de ADE, fossem bons para se medir o potencial dos fungos na produçāo de pectinases, foi feito um estudo de correlação entre estes (conforme item 3.14). A correlação estimada entre os dois critérios de seleção em meio sólido foi de $0,32^{*}$ (significativo a $5,0 \%$ de probabilidade), portanto muito baixa. Estes resultados, de certa forma, poderiam justificar as diferenças obtidas entre as linhagens avaliadas pelos dois critérios de seleção em meio sólido.

Entretanto, só existiria interesse em selecionar para algum desses caracteres se houvesse uma boa correlação entre esses e os caracteres analisados em cultura submersa, na hipótese desses últimos possivelmente estarem mais próximos da real capacidade dos fungos em produzir pectinases. Sendo assim, as linhagens que foram significativamente $(P<0,05)$ superiores a linhagem padräo FP/107 apontado pelo Teste de Tukey (tabelas 4 e 5) foram submetidas a seleção em cultura submersa. 
TABELA 4: Análise de variância do parâmetro indice de Relação Enzimática (IRE), analisado em meio sólido e resultados do Teste de Tukey para as linhagens fúngicas avaliadas ( 3 repetições).

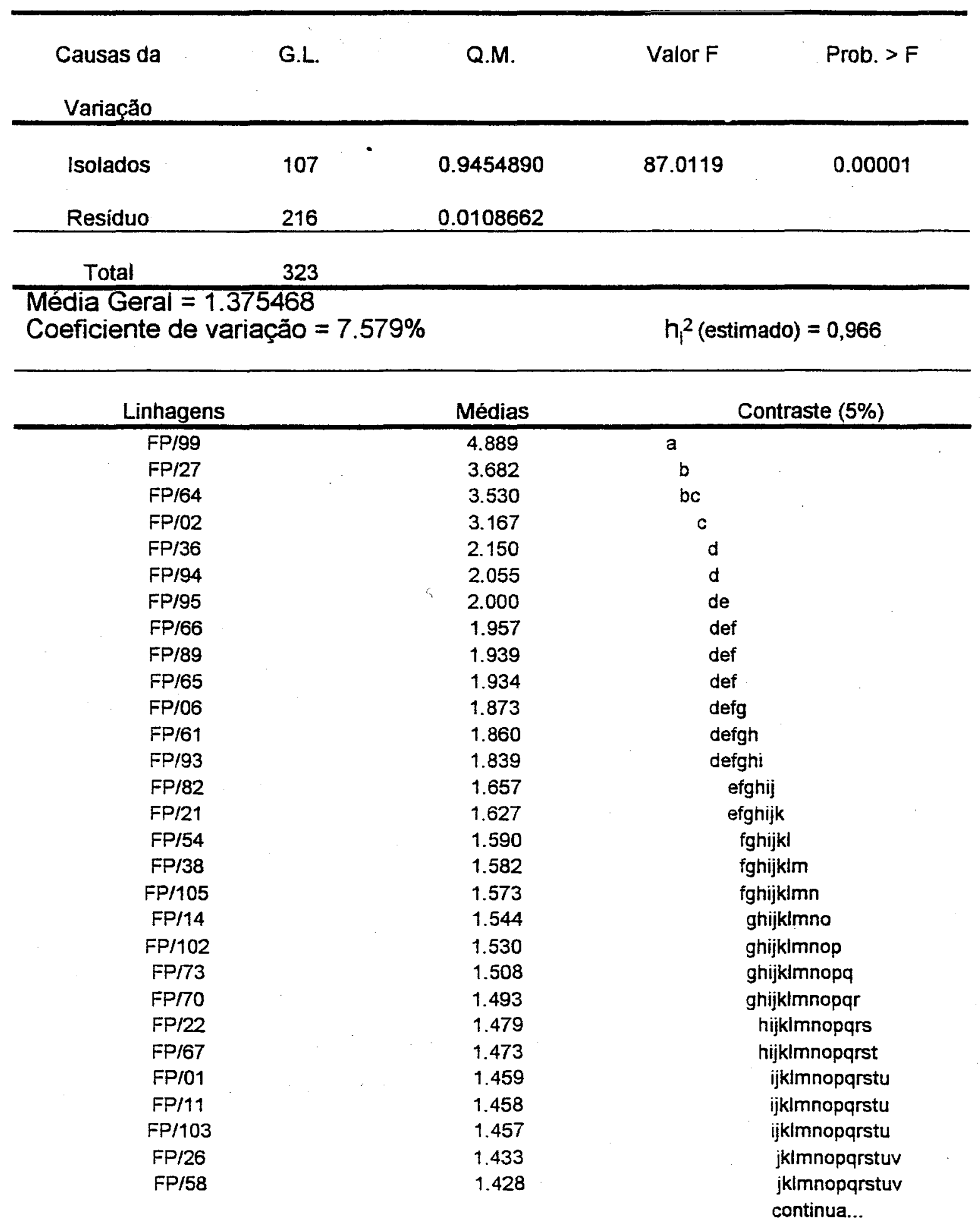


continuação da tabela 4

\begin{tabular}{|c|c|c|c|}
\hline Linhagens & : & Médias & Contraste $(5 \%)$ \\
\hline FP/106 & & 1.407 & jklmnopqrsturw \\
\hline FP/53 & 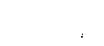 & 1.371 & jkimnopqrstumw \\
\hline FP/59 & & 1.367 & jklmnopqrstumw \\
\hline FP/55 & & 1.349 & jklmnopqrstuww \\
\hline FP/31 & & 1.324 & jklmnopqrstuww \\
\hline FP/03 & & 1.318 & jkImnopqrstumw \\
\hline FP/45 & - & 1.302 & jkImnopqrstuww \\
\hline FP/86 & & 1.299 & jkimnopqrstumw \\
\hline FP/97 & & 1.293 & jkImnopqrstuww \\
\hline $\mathrm{FP} / 46$ & & 1.290 & jklmnopqrstuww \\
\hline FP/39 & & 1.277 & jkImnopqrstumw \\
\hline FP/15 & & 1.273 & jkimnopqrstuww \\
\hline FP/60 & & 1.271 & jkimnopqrstuww \\
\hline FP/62 & & 1.266 & kImnopqrsturw \\
\hline FP/08 & & 1.265 & klmnopqrstuww \\
\hline FP/49 & & 1.258 & kImnopqrstunw \\
\hline FP/23 & & 1.245 & kImnopqrsturw \\
\hline FP/104 & & 1.250 & kImnopqrsturw \\
\hline FP/100 & & 1.250 & kimnopqrstuww \\
\hline FP/88 & & 1.246 & kImnopqrstuww \\
\hline$F P / 13$ & & 1.244 & klmnopqrstuww \\
\hline FP/17 & & 1.233 & Imnopqrsturw \\
\hline FP/48 & & 1.229 & Imnopqrsturw \\
\hline$F P / 34$ & & 1.229 & Imnopqrstumw \\
\hline$F P / 32$ & & 1.225 & Imnopqrstuuw \\
\hline FP/24 & & 1.224 & Imnopqrstuww \\
\hline $\mathrm{FP} / 78$ & & 1.217 & Imnopqrstuw \\
\hline$F P / 47$ & & 1.216 & Imnopqrstuww \\
\hline FP/44 & & 1.206 & Imnopqrstuww \\
\hline FP/40 & & 1.206 & Imnopqrstunw \\
\hline FP/41 & & 1.197 & mnopqrstunw \\
\hline FP/33 & & 1.189 & nopqrstumw \\
\hline FP/42 & & 1.188 & nopqrstuw \\
\hline FP/69 & & 1.176 & opqrstumw \\
\hline FP/80 & & 1.167 & opqrstumw \\
\hline FP/81 & & 1.163 & opqrstuww \\
\hline FP/71 & & 1.163 & opqrsturw \\
\hline $\mathrm{FP} / 30$ & & 1.160 & opqrstunw \\
\hline FP/79 & & 1.153 & pqrsturw \\
\hline $\mathrm{FP} / 43$ & & 1.149 & pqrstuww \\
\hline FP/85 & & 1.148 & pqrstumw \\
\hline FP/63 & & 1.141 & qrsturw \\
\hline FP/84 & & 1.140 & qrstunw \\
\hline FP/12 & & 1.139 & qrsturw \\
\hline FP/76 & & 1.137 & qrsturw \\
\hline$F P / 20$ & & 1.110 & $\begin{array}{l}\text { rstuww } \\
\text { continua... }\end{array}$ \\
\hline
\end{tabular}


continuação da tabela 4

\begin{tabular}{|c|c|c|}
\hline Linhagens & Médias & Contraste $(5 \%)$ \\
\hline FP/56 & 1.107 & rstuww \\
\hline FP $/ 74$ & 1.106 & stumw \\
\hline FP $/ 72$ & 1.104 & stumw \\
\hline FP/87 & 1.101 & sturw \\
\hline FP/90 & 1.101 & stumw \\
\hline FP/50 & 1.101 & stum \\
\hline FP/51 & 1.091 & turw \\
\hline FP/96 & 1.090 & turw \\
\hline FP/35 & $1.087^{-}$ & unw \\
\hline FP/07 & 1.084 & unw \\
\hline FP/52 & 1.083 & $u n w$ \\
\hline FP/107 & 1.083 & unw \\
\hline FP/29 & 1.070 & $w$ \\
\hline FP/25 & 1.064 & vw \\
\hline FP/O4 & 1.062 & $w w$ \\
\hline FP/98 & 1.062 & $w$ \\
\hline FP/101 & 1.055 & $w w$ \\
\hline FP/91 & 1.053 & ww \\
\hline FP/57 & 1.052 & $w$ \\
\hline FP/18 & 1.049 & $\mathrm{vw}$ \\
\hline FP/28 & 1.047 & vw \\
\hline FP/19 & 1.024 & ww \\
\hline FP/75 & 1.017 & $w$ \\
\hline
\end{tabular}

Médias seguidas por letras distintas diferem entre si ao nivel designificáncia indicado.

TABELA 5: Análise de variância do parâmetro Área de Degradação Enzimática (ADE) analisado em meio sólido e resultado do Teste de Tukey para as linhagens fúngicas avaliadas (três repetições).

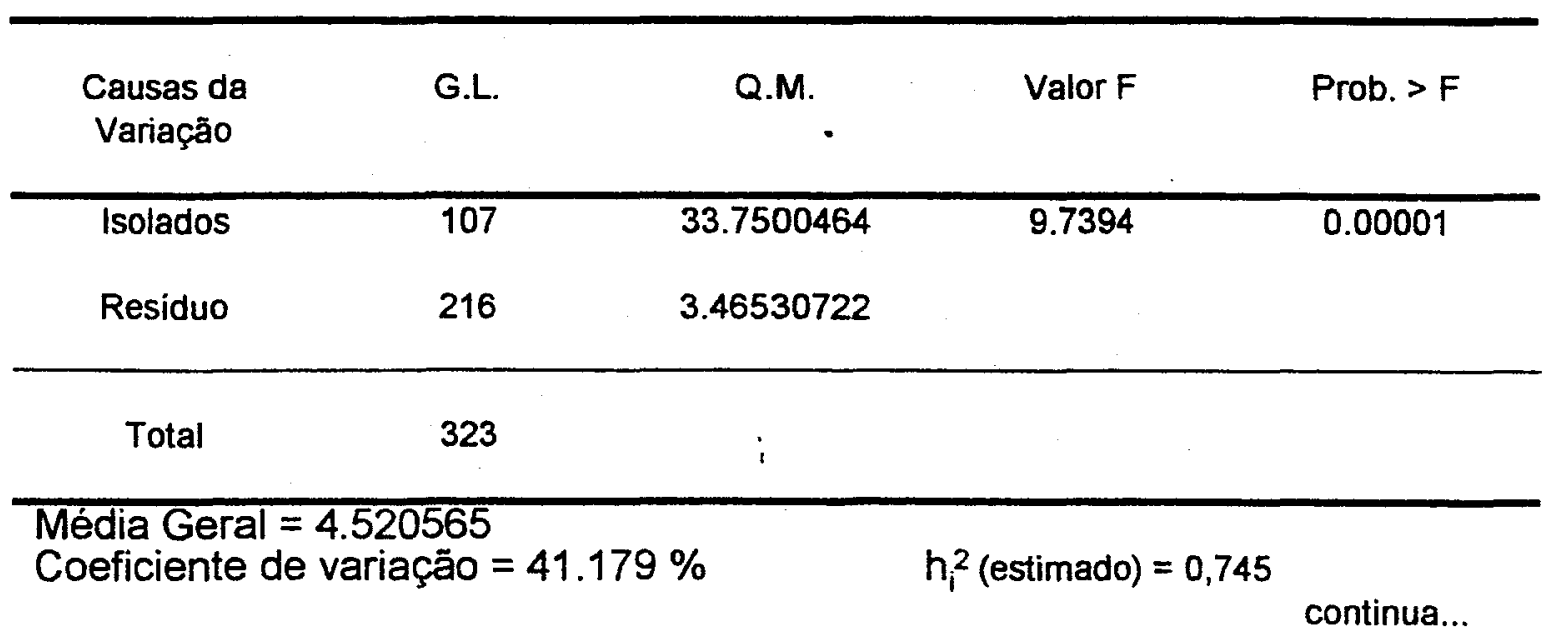


continuação da tabela 5

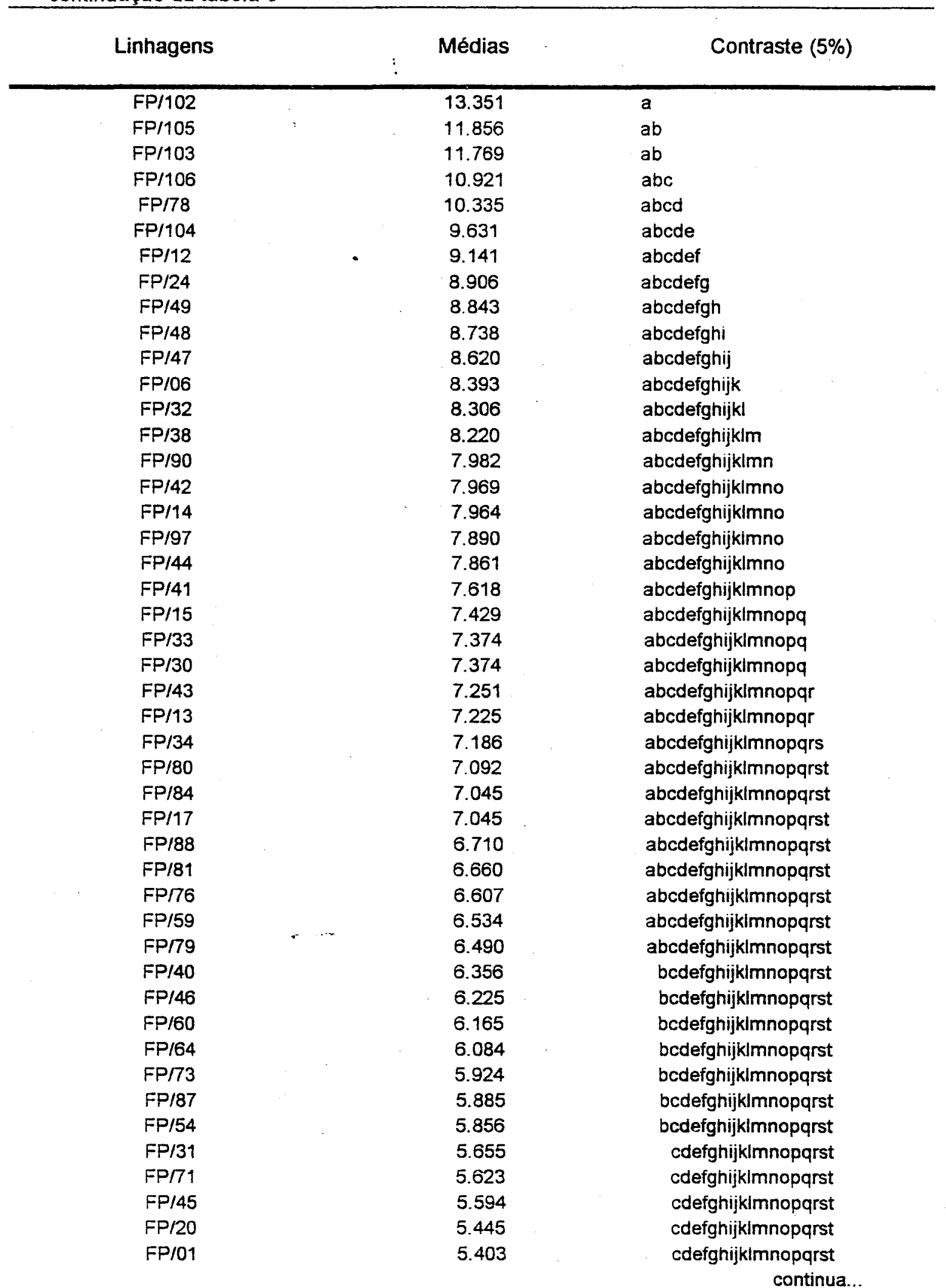


continuação da tabela 5

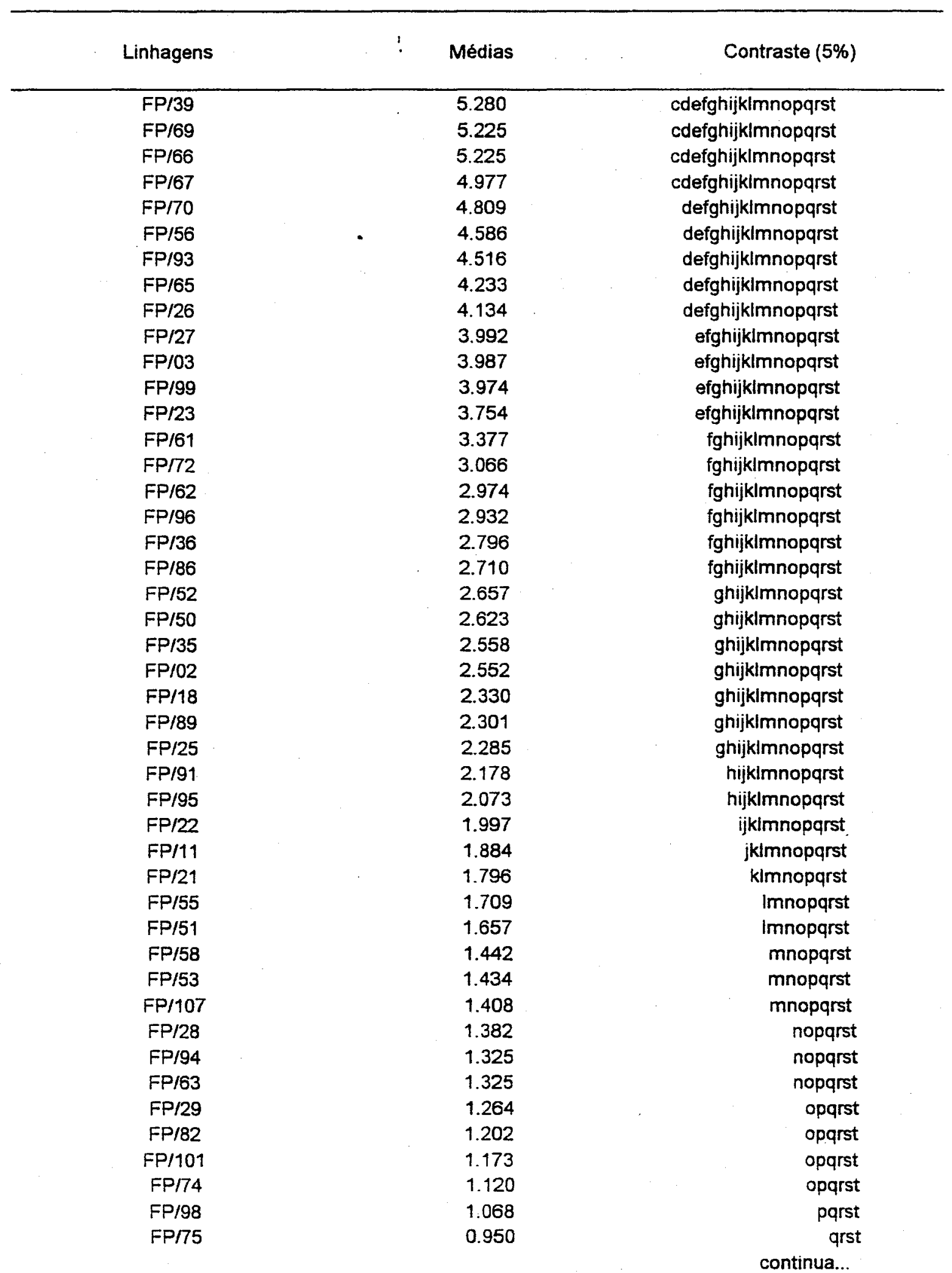


continuação da tabela 5

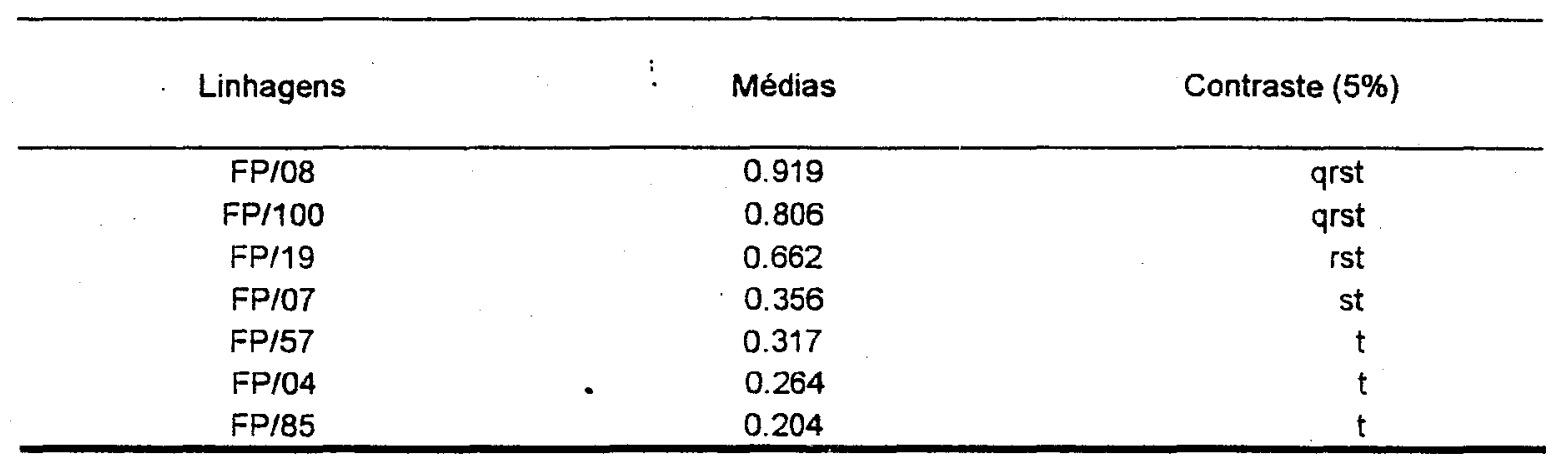

Médias seguidas por letras distintas diferem entre si ao nivel de significância indicado.

\subsubsection{Seleção em cultura submersa}

$\mathrm{Na}$ busca de maiores esclarecimentos, as linhagens fúngicas isoladas foram avaliadas em cultura submersa conforme item (3.7.), e selecionadas segundo sua produtividade enzimática nas mesmas condições de meio de cultura, temperatura, e tempo de incubação quando avaliadas em placas (meio sólido).

Entretanto, o meio de cultura original foi tamponado como descrito no item (3.4.2. Mod.2), pois verificou-se na literatura a importância que o controle do pH impõe. No meio de HANKIN e ANAGNOSTAKIS (1975), preparado como originalmente, constatava-se um pH em torno de 3,5-3,7. Tal $\mathrm{pH}$ tem sido indicado como faixa ótima para biossintese da enzimas pectinolíticas, tanto para fermentaçäo submersa como para semi-sólida (FUMIAN, 1987; MAIORANO, 1990), respectivamente.

FRIDUREK ( 1981), avaliando a síntese do complexo pectinolítico por Aspergillus niger 71 em condições de cultivo submerso, verificou que a produção de enzimas pectinolíticas dependiam não somente do $\mathrm{pH}$ do meio de fermentação mas também do tipo de tampāo utilizado. Nas condiçōes experimentais utilizadas obteve uma máxima produção de poligalacturonase em pH 4,0-4,5 e tampão Mcllvaine. Dessa forma, utilizou-se o meio de Hankin para a seleção em cultura submersa adotando o pH 3.6., tamponado com o tampão de Mcllvaine, conforme indicado no item (3.4.2. Mod.2). 
O emprego da avaliação em cultura submersa visava inicialmente observar a existência de alguma correlação entre seus resultados e o Índice de Relação Enzimática ou a Ȧrea de Degradação. Enzimática, que foram os parâmetros avaliados na seleção em placas (meio sólido), já que com freqüência são encontrados na literatura relatos sobre a existência de correlação entre testes semiquantitativos (meio sólido) e quantitativos (meio líquido).

MANDELS (1975) e MONTENECOURT \& EVELEIGH (1977), descreveram que linhagens de Trichoderma reesei QM6a e a mutante QM9414, apresentaram correlação entre os resultados obtidos em meio sólido e líquido, indicando, assim, a validade do uso de técnicas semi-quantitativas para "screening" rápidos. Tal correlação também foi efetiva para isolados selvagens de fungos filamentosos (BERTOLINI, 1987) e para Humícola sp (ROUMAS, 1988), quando avaliados bioquimicamente quanto a atividade celulolitica.

Entretanto, esta correlaçăo positiva entre os parâmetros avaliados em meio sólido e líquido, quando se estudou a produção de enzimas do complexo celulolítico entre linhagens selvagens elou especificas, poderia não ser verdadeira quando se avalia a produção de outros complexos enzimáticos. Assim sendo, na busca de maior clareza, as oitenta e sete linhagens indicadas na primeira seleçāo (meio sólido) que apresentaram-se significativamente $(P<$ 0,05 ) superiores à linhagem (FP/107) foram avaliadas em cultura submersa, onde foi estabelecido previamente um critério de seleção para corte (percentagem de redução da viscosidade maior ou igual a 50\%).

Dentre as 87 linhagens avaliadas em cultura submersa, apenas 31 apresentaram niveis de reduçāo de viscosidade da pectina superior a $50 \%$, tendo sido as demais descartadas. Os resultados obtidos foram sumarizados na tabela 6 . Nesta, observa-se que apenas $25,8 \%$ dos isolados (oito linhagens) apresentaram valores de atividade especifica ( Uesp) maiores que a linhagem padrão (FP/107), que foi de 647,53 Uesp, e cerca de $87 \%$ das linhagens (27 isolados) apresentaram valores de Utotal superiores a linhagem referência (FP/107), que foi de 32,83 UTotal. 
TABELA 6: Seleção em cultura submersa das linhagens selvagens (medidas de atividade enzimática no tempo de 72 horas).

\begin{tabular}{crrr}
\hline Linhagens & $\begin{array}{c}\text { U total } \\
\text { (un. } \times 50 \mathrm{ml})\end{array}$ & $\begin{array}{c}\text { U esp. } \\
\text { (U total/g } \\
\text { m.seca) }\end{array}$ & pH final \\
\hline FP/17 & 34,75 & 414,00 & 3,45 \\
FP/20 & 111,75 & 377,00 & 5,72 \\
FP/21 & 66,19 & 1833,52 & 3,54 \\
FP/24 & 119,25 & 481,00 & 5,91 \\
FP/30 & 165,75 & 222,00 & 6,55 \\
FP/31 & 177,00 & 618,00 & 4,08 \\
FP/32 & 115,06 & 158,00 & 3,96 \\
FP/33 & 61,00 & 294,00 & 5,82 \\
FP/34 & 75,08 & 286,00 & 3,64 \\
FP/38 & 30,39 & 602,98 & 3,57 \\
FP/39 & 169,64 & 1156,37 & 3,28 \\
FP/40 & 153,34 & 639,98 & 3,71 \\
FP/42 & 275,65 & 1129,71 & 3,81 \\
FP/43 & 59,81 & 202,27 & 3,70 \\
FP/44 & 56,57 & 189,32 & 5,66 \\
FP/45 & 127,49 & 584,01 & 3,74 \\
FP/46 & 209,75 & 861,75 & 4,77 \\
FP/50 & 56,83 & 499,82 & 3,78 \\
FP/51 & 59,52 & 517,56 & 3,76 \\
FP/52 & 58,11 & 504,43 & 3,78 \\
FP/53 & 73,58 & 958,07 & 3,46 \\
FP/60 & 24,18 & 591,19 & 3,43 \\
FP/69 & 125,06 & 1591,04 & 3,02 \\
FP/70 & 35,32 & 511,14 & 3,30 \\
FP/71 & 35,22 & 422,81 & 3,90 \\
FP/72 & 62,47 & 517,13 & 3,19 \\
FP/76 & 53,22 & 1482,45 & 3,57 \\
FP/79 & 33,84 & 446,44 & 3,80 \\
FP/83 & 57,70 & 1259,83 & 3,53 \\
FP/88 & 24,14 & 511,44 & 3,13 \\
FP/107/Padrão) & 32,83 & 647,53 & 3,60 \\
\hline & & & \\
\hline & & & \\
\hline
\end{tabular}

Os dados contidos na tabela 6 revelam uma disparidade entre os parâmetros avaliados em cultura submersa, quais sejam, Unidade Especifica (Uesp) e Unidade Total (Utotal), pois os melhores valores encontrados por um parâmetro não necessariamente indicam as mesmas linhagens com os melhores valores apontadas pelo outro. No entanto, avaliando-se esta tabela 
de forma global, verifica-se que os maiores valores obtidos pelas linhagens selvagens, através do cálculo da Unidade especifica (Uesp), quando comparado com a linhagem padrão FP/107, estariam dentre aquelas indicadas como superiores à linhagem referência quanto a atividade enzimática total no caldo fermentado dado pelo parâmetro (Utotal), podendo como isto denotar algum tipo de correlaçāo.

Assim, para continuidade dos estudos deste trabalho utilizou-se todas as linhagens que aprèsentaram valores de atividade especifica (Uesp) maiores que o obtido pela linhagem referência FP/107, que foi de 647,53 Uesp (tabela 6).

Dessa forma, segundo este critério, as linhagens mais promissoras foram: FP/21; FP/69; FP/76; FP/83; FP/39; FP/42; FP/53; FP/46, com valores de Uesp de 1833,52;1591,04;1482,45; 1259,83; 1156,37; 1129,$71 ; 958,07 ; 861,75$; respectivamente. Estas linhagens foram submetidas a ensaios cinéticos de crescimento e avaliação da atividade enzimática em três repetiçōes. Tais resultados serão discutidos a seguir no item 4.3.

Em paralelo, por ser considerado de extrema importância, foi realizado um estudo de correlação entre os parâmetros avaliados em meio sólido e líquido, no sentido de se obter indícios mais claros, de qual ou quais seriam os critérios ou indices para se fazer uma seleção; já que nas duas condições (meio sólido e líquido), os resultados obtidos pelos parâmetros de seleção utilizados foram contraditórios, gerando certa dúvida na escolha de um deles para seleção das linhagens.

Entretanto, embora tenha sido feita a escolha das linhagens selvagens promissoras através da Uesp, os dados obtidos pelas 31 linhagens na seleção submersa foram correlacionados com os resultados observados para estas mesmas linhagens na primeira seleção (meio sólido). Tais dados foram analisados utilizando-se o coeficiente de correlação simples.

Os resultados obtidos através desta análise constam da tabela 7. Nesta, observa-se que as correlações entre os caracteres avaliados em meio sólido e aqueles avaliados em meio líquido foram pequenas, apesar de algumas serem significativas a $5 \%$ de probabilidade, como por exemplo no caso da variável $E$ (massa seca final), que estabelece correlação entre a maioria dos caracteres avaliados com diferentes niveis de significância. 
Percebe-se também que a variável $D$ (Uesp), não apresenta correlações significativas com as demais variáveis, ou estas são negativas, portanto cuidados adicionais devem ser tomados quando tal variável for utilizada como parâmetro de seleção.

Observa-se ainda que dentro da seleção em meio sólido a correlação foi baixa para as variáveis $A$ (IRE) e $B(A D E)$, embora tenham sido significativas a nivel de $5 \%$ de probabilidade.

Tabela 7: Coeficiente de correlação simples entre pares de dados, utilizando as variáveis envolvidas na seleção em meio de cultura sólido $(A$ e $B)$ e em cultura submersa (C, D e E).

\begin{tabular}{cccccc}
\hline Variáveis & A & B & C & D & E \\
\hline A & - & $0,32^{*}$ & $0,12^{\text {ns }}$ & $0,022^{\text {ns }}$ & $-0,06^{\text {ns }}$ \\
B & - & - & $0,26^{\text {ns }}$ & $-0,19^{\text {ns }}$ & $0,35^{*}$ \\
C & - & - & - & $0,29^{\text {ns }}$ & $0,60^{\text {** }}$ \\
D & - & - & - & - & $-0,42^{\star *}$ \\
E & - & - & - & - & - \\
\hline
\end{tabular}

Variáveis: $\mathrm{A}=$ índice de Relação Enzimática; $\mathrm{B}=$ Área de Degradação Enzimática; $\mathrm{C}=$ Unidade total; $D=$ Unidade especifica; $E$ = Massa seca final.

$*$ = significativo a $5 \%, \quad=$ significativo a $1 \%,=$ significativo a $0,1 \% ;$ ns $=$ não significativo

Entretanto, a seleçāo em meio sólido só se justificaria se o produto da herdabilidade da característica sob seleção pela correlação entre esta e a característica de interesse, aquela obtida em meio líquido, fosse superior à herdabilidade desta última. No meio líquido, não obstante, foram avaliadas duas importantes características (Atividade enzimática total - UTotal e Massa celular seca - MS) e, a partir destas, foram obtidos alguns índices de seleção baseadas na combinação destas: um deles, denominado IUtms, é o produto das duas características; o outro, denominado IC, foi obtido pelo método clássico de SMITH (1936); e, por último, um índice denominado de $\mathrm{IH}^{1}$ onde os coeficientes que multiplicam as duas caracteristicas são os inversos de suas respectivas herdabilidades.

1 Índice proposto por SOUZA JR, C. L. - ESALQ/USP (não publicado). Comunicação pessoal a FERNANDES, J. S. C. - UFPR (1994). 
As caracteristicas avaliadas em meio sólido foram então correlacionadas com os obtidos em meio líquido e com os indices resultantes de combinações entre estas.

Os resultados obtidos constam da Tabela 8. Nesta, observa-se que para os índices de seleção e os critérios de avaliação aplicados em meio sólido as correlações não foram significativas para a variável (a), e para a variável (b) verifica-se uma baixa correlação para os índices IH e IUTMS, apontando valores idênticos $\left(0,35^{\star}\right)$, significativos a $5 \%$ de probabilidade, bem como valores não significativos para o índice clássico (IC).

Verifica-se também pela Tabela 8 , uma correlação bastante alta entre os indices e os critérios de seleção utilizados em meio líquido ( $C$ e $D$ ), tendo sido obtido para a variável $C$ valores superiores a 0,80 para os indices IH e IUTMS, e 0,94* para IC, ambos significativos a 0,1\%. Para a variável D foram obtidos valores superiores a $0,90^{\star \star}$, significativos a $0,1 \%$ apenas para os índices IH e IUTMS, enquanto que para IC a correlação obtida não foi significativa. Estes resultados sugerem que provavelmente a variável mais indicada como critério de seleção em meio líquido seria a $\mathrm{C}$, que representa Utotal, por apresentar uma alta correlação entre os critérios e índices de seleção.

Ainda pela Tabela 8, observa-se que o produto da herdabilidade dos indices IC, IH e IUTMS (valores entre parênteses) pelas suas correlações com qualquer parâmetro avaliado em meio sólido (variáveis $A$ e $B$ ) e em meio líquido (variáveis $\mathrm{C}$ e $\mathrm{D}$ ), apresentam resultados que corroboram com 0 exposto acima, no sentido de destacar novamente o parâmetro Utotal (C), variável medida em meio líquido, e apontar IC como como melhor índice para seleção de linhagens. Pode-se ainda inferir que se a escolha de linhagens for feita a partir da variável $C$ indiretamente, esta escolha não seria diferente daquela indicada por IC, já que a correlação entre estes critérios é bastante alta e o produto de sua herdabilidade também.

Cabe salientar que, embora a primeira seleção das linhagens fúngicas em cultura submersa não tenha sido feita através do melhor índice ou parâmetro indicado no estudo de correlação, tal análise foi importante para que em futuros trabaihos melhores critérios para seleção possam ser aplicados. 
Tabela 8: Coeficiente de correlação simples entre pares de dados aplicados para os índices: IC, IH e IUTMS e para os parâmetros de avaliação na seleção em meio sólido ( $A$ e $B$ ) e em meio líquido ( $C$ e $D$ ).

\begin{tabular}{|c|c|c|c|}
\hline \multirow[b]{2}{*}{ Variáveis e $\left(h^{2} a\right)$} & \multicolumn{3}{|c|}{ Indices e $\left(\mathrm{h}^{2} \mathrm{a}\right)$} \\
\hline & IC $\left(h^{2} a=0,63\right)$ & $I H\left(h^{2} a=0,58\right)$ & IUTMS $\left(h^{2} a=0,44\right)$ \\
\hline$A\left(h^{2} a=0,97\right)$ & $0,18^{\text {ns }}(0,11)^{P}$ & $0,003^{\text {ns }}(0,00)^{P}$ & $0,014^{\mathrm{nS}}(0,00)^{\mathrm{P}}$ \\
\hline$B\left(h^{2} a=0,74\right)$ & $0,17^{\text {ns }}(0,10)^{P}$ & $0,35^{\star}(0,20)^{P}$ & $0,35^{*}(0,15)^{P}$ \\
\hline$C\left(h^{2} a=0,62\right)$ & $0,94^{\cdots}(0,59)^{P}$ & $0,81 \ldots(0,47)^{P}$ & $0,84^{\star \star * *}(0,37)^{P}$ \\
\hline$D\left(h^{2} a=0,50\right)$ & $0,30^{\text {ns }}(0,19)^{P}$ & $0,95^{m-10}(0,55)^{P}$ & $0,94^{\ldots}(0,41)^{P}$ \\
\hline \multicolumn{4}{|c|}{ 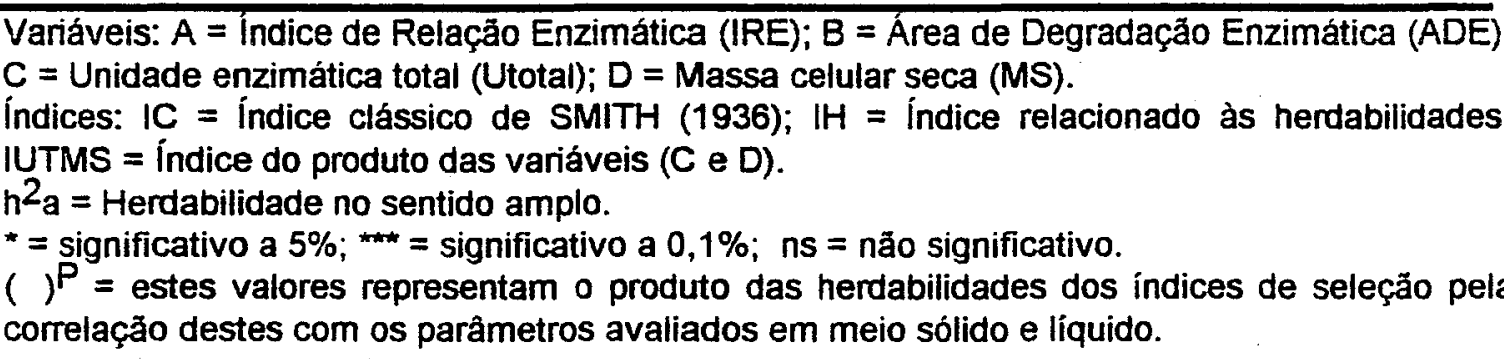 } \\
\hline
\end{tabular}




\subsection{Cinética de crescimento com avaliação da atividade enzimática das linhagens selecionadas}

Como mencionado no item 4.2.2, as linhagens foram selecionadas em meio líquido, tomando-se aquelas que expressaram Uesp maiores que o obtido pela linhagem referência FP/107. Isto foi feito antes do conhecimento dos resultados do estudo de correlação. $\mathrm{Na}$ ocasião tal critério foi adotado por ser considerado adequado para seleção em cultura submersa. Dessa forma, as linhagens assim selecionadas, quais sejam, FP/21, FP/39, FP/42, FP/46, FP/53, FP/69, FP/76, FP/83, foram submetidas à fermentação submersa para avaliação de sua cinética de crescimento, bem como a avaliação da atividade enzimática.

Dentre as linhagens fúngicas selecionadas, somente as linhagens FP/39 e FP/53, não deram prosseguimento nos ensaios cinéticos, pois tais linhagens perderam a capacidade de esporulação durante os repiques, tendo sido descartadas posteriormente. Com as demais linhagens tais ensaios foram realizados com três repetiçōes (para cada linhagem).

Embora a seleção inicial não tenha sido realizado através do Índice ou parâmetro mais indicado à seleçăo, os resultados obtidos nestes ensaios cinéticos, bem como nos ensaios posteriores, foram avaliados segundo o melhor critério no estudo de correlação, ou seja, utilizou-se como critério de seleção a variável Utotal por possuir alta correlação com melhor índice de seleção (IC) 0,94 significativo a 0,1\%.

Os resultados obtidos nos ensaios podem ser observados na Tabela 9. Nesta, pode-se constatar o desenvolvimento de,cada linhagem durante um período de cinco dias, verificando-se uma grande dispersão nas atividades de cada uma das linhagens em cada um dos tempos de fermentação, já que, de modo geral, estas apresentavam valores de desvio padrão relativamente altos. Observa-se também que os valores da Utotal no tempo de 72 horas de fermentação de cada linhagem não reproduziram os resultados encontrados na seleção em meio líquido (Tabela 6), exceção feita para as linhagens FP/21, 76 e 107, cujos valores alcançados na cinética se aproximaram aos obtidos na seleção em cultura submersa. 
Tais distorções podem ser atribuídas tanto a erros inerentes a técnica como, falta de repetição da seleção em cultura submersa, ou por problemas não computados relacionados a fatores ambientais, assim como a própria variabilidade entre as espécies estudadas.

Os resultados obtidos e sumarizados na Tabela 9 foram submetidos a uma análise de variância utilizando-se um delineamento inteiramente casualizado, onde se analisou as caracteristicas observadas para crescimento, através dos dados de massa celular seca (MS), e para atividade enzimática por meio da medida dada em unidade total enzimática (Utotal).

As Tabelas 10 e $11 ; 12$ e 13, apresentam respectivamente o quadro da análise de variância bem como o teste de Tukey para as médias de cada caráter utilizado na avaliação desse experimento.

A análise de variância para os valores médios de MS (Tabela 10) apresentam valores de $F$ significativos ao nivel de $5 \%$ de probabilidade, enquanto os resultados do teste de Tukey evidenciaram diferenças consideráveis para o parâmetro avaliado (Tabela 11).

Verificou-se também que, entre as linhagens selecionadas (Tabela 9), a que apresentou a maior atividade pectinolítica foi a FP/83, expressando uma atividade total de 267,75 (Utotal) no tempo de 120 horas, representando 2,4 vezes mais do que a atividade produzida pela linhagem controle, FP/107. Pela Figura 8, verifica-se claramente a superioridade da linhagem FP/83, frente a FP/107 (padrão), bem como entre alguns dos selvagens selecionados como mais promissores. Neste caso, a análise de variância e o teste de Tukey realizado para os valores médios de Utotal (tabelas 12 e 13) corroboram essa exposição, pois é possivel verificar a linhagem FP/83 diferindo das demais ao nível de significância indicado.

As linhagens selecionadas em cultura submersa foram posteriormente classificadas taxonômica e citologicamente. Tais linhagens também foram mantidas no Banco de Linhagems do Agrupamento de Biotecnologia da Divisão de Química do Instituto de Pesquisas Tecnológicas do Estado de São Paulo S.A. - IPT, em dois métodos de preservação, ou seja, liofilização e criopreservação.

A linhagem FP/83, que apresentou os melhores resultados nas condiçōes testadas, demonstrando ser bastante promissora na produção de 
pectinases, também foi submetida a irradiação de luz ultravioleta, na tentativa de serem encontrados mutantes morfológicos com a capacidade de produção enzimática aumentada.

TABELA 9: Dados da cinética de crescimento com avaliação da produção enzimática dos isolados selvagens selecionados. Os valores representam a média de três experimentos independentes e seu desvio padrão.

\begin{tabular}{|c|c|c|c|c|c|c|}
\hline \multirow[t]{3}{*}{ Linhagem } & \multirow{3}{*}{$\begin{array}{c}\begin{array}{c}\text { Tempo de } \\
\text { Fermentaçåo } \\
\text { (horas) }\end{array} \\
24 \\
48\end{array}$} & \multicolumn{2}{|c|}{$\begin{array}{c}U \text { Total } \\
(U \times 50 \mathrm{ml})\end{array}$} & \multicolumn{2}{|c|}{ Massa Seca (mg) } & pH final \\
\hline & & 26,00 & 5,63 & 26,07 & 7,85 & 3,56 \\
\hline & & 48,60 & 13,84 & 40,87 & 9,10 & 3,48 \\
\hline \multirow{5}{*}{$F P / 21$} & 72 & 60,75 & 17,86 & 45,97 & 6,81 & 3,71 \\
\hline & 96 & 69,58 & 13,29 & 65,23 & 8,42 & 3,73 \\
\hline & 120 & 58,08 & 16,79 & 77,30 & 11,00 & 3,76 \\
\hline & 24 & 5,25 & 6,36 & 52,90 & 1,27 & 3,35 \\
\hline & 48 & 12,87 & 2,30 & 43,70 & 14,99 & 3,70 \\
\hline \multirow[t]{5}{*}{ FP/42 } & 72 & 20,87 & 4,77 & 63,45 & 4,74 & 4,17 \\
\hline & 96 & 26,75 & 13,79 & 66,20 & 19,52 & 3,81 \\
\hline & 120 & 37,00 & 20,15 & 67,45 & 29,34 & 4,22 \\
\hline & 24 & 13,29 & 0,56 & 42,08 & 12,12 & 3,69 \\
\hline & 48 & 19,25 & 9,00 & 57,50 & 9,00 & 3,55 \\
\hline \multirow[t]{5}{*}{ FP/46 } & 72 & 75,53 & 10,49 & 75,53 & 10,49 & 4,06 \\
\hline & 96 & 87,87 & 9,13 & 87,87 & 9,13 & 4,10 \\
\hline & 120 & 43,01 & 10,89 & 101,23 & 12,85 & 4,25 \\
\hline & 24 & 21,83 & 3,26 & 10,93 & 3,85 & 3,52 \\
\hline & 48 & 27,42 & 1,66 & 24,20 & 9,82 & 3,54 \\
\hline \multirow[t]{5}{*}{ FP/69 } & 72 & 50,33 & 2,75 & 51,87 & 1,27 & 3,67 \\
\hline & 96 & 71,57 & 24,80 & 74,97 & 12,70 & 3,35 \\
\hline & 120 & 75,42 & 17,00 & 75,90 & 10,43 & 3,34 \\
\hline & 24 & 20,14 & 5,83 & 29,35 & 5,44 & 3,55 \\
\hline & 48 & 24,06 & 6,83 & 59,15 & 1,77 & 3,60 \\
\hline \multirow[t]{5}{*}{ FP/76 } & 72 & 42,71 & 24,49 & 68,00 & 5,09 & 3,87 \\
\hline & 96 & 28,01 & 8,47 & 69,45 & 17,04 & 3,89 \\
\hline & 120 & 30,56 & 8,63 & 81,65 & 20,29 & 3,98 \\
\hline & 24 & 27,75 & 3,54 & 42,40 & 10,04 & 3,65 \\
\hline & 48 & 99,37 & 20,68 & 60,30 & 17,54 & 3,61 \\
\hline \multirow[t]{3}{*}{ FP/83 } & 72 & 127,00 & 18,38 & 53,65 & 8,84 & 3,71 \\
\hline & 96 & 177,53 & 29,16 & 64,77 & 2,04 & 3,89 \\
\hline & 120 & 267,75 & 43,09 & 68,73 & 18,58 & 4,06 \\
\hline
\end{tabular}




\begin{tabular}{ccrrrrr} 
continuação & da tabela 9 & & & & \\
\hline Linhagem & $\begin{array}{c}\text { Tempo de } \\
\text { Fermentação } \\
\text { (horas) }\end{array}$ & \multicolumn{1}{c}{$\begin{array}{c}\text { U Total } \\
(U \times 50 \mathrm{ml})\end{array}$} & & Massa Seca (mg) & pH final \\
& 24 & 5,22 & 5,07 & 39,23 & 6,51 & 3,61 \\
FP/107 & 48 & 22,36 & 7,84 & 62,75 & 3,32 & 3,85 \\
(padrão) & 72 & 38,46 & 21,06 & 79,43 & 15,46 & 3,84 \\
& 96 & 64,34 & 12,58 & 92,27 & 3,71 & 3,97 \\
& 120 & 113,16 & 9,23 & 92,93 & 18,90 & 4,18 \\
\hline
\end{tabular}

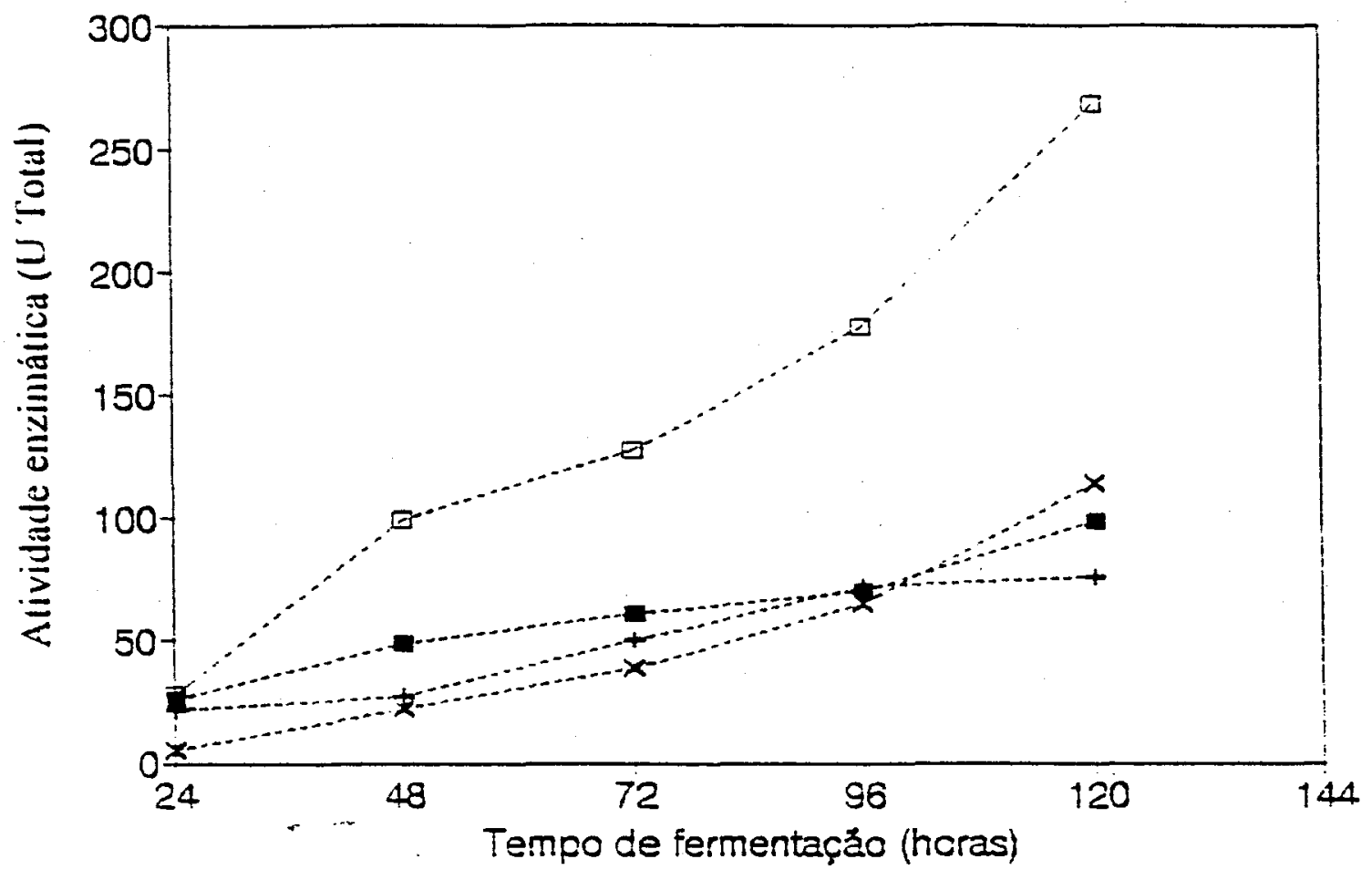

Figura 8: Cinética de crescimento com avaliação da atividade enzimática dos isolados selvagens selecionados. 
Tabela 10: Análise de variância da massa celular seca $(\mathrm{mg})$ obtida pelas linhagens selvagens selecionadas FP/21, FP/42, FP/46, FP/69, FP/76, FP/83 e pela linhagem padrão FP/107, nos ensaios cinéticos realizados.

\begin{tabular}{lcccc}
\multicolumn{1}{c}{$\begin{array}{c}\text { Causas da } \\
\text { variação }\end{array}$} & G.L. & S.Q. & Valor F & Prob. $>F$ \\
\hline Linhagem & 6 & 7202.4147608 & 7.8638 & 0.00008 \\
$\begin{array}{l}\text { Tempo de fermentação } \\
\text { (TF) }\end{array}$ & 4 & 22192.6167476 & 36.3457 & 0.00001 \\
Linhagem $\times$ TF & 24 & 3487.6155148 & 0.9520 & 0.54231 \\
Residuo & 35 & 5342.7302174 & - & - \\
Total & 69 & 38225.3772406 & - & - \\
\hline Média geral $=58.639713$ & & Coeficiente de variação $=21.07 \%$ & \\
\hline
\end{tabular}

Tabela 11: Teste de Tukey para os valores médios da massa celular seca (mg) obtidos pelas linhagens selvagens selecionadas FP/21, FP/42, FP/46, FP/69, FP/76, FP/83 e pela linhagem padrão FP/107, nos ensaios cinéticos realizados.

\begin{tabular}{ccccccc}
\hline $\begin{array}{l}\text { Número de } \\
\text { Ordem }\end{array}$ & $\begin{array}{c}\text { Número de } \\
\text { Tratamento }\end{array}$ & Nome & $\begin{array}{l}\text { Número de } \\
\text { repetição }\end{array}$ & Mëdias & $\begin{array}{l}\text { Médias } \\
\text { originais }\end{array}$ & $5 \%$ \\
\hline 1 & 7 & FP/107 & 10 & 72.670000 & 72.670000 & a \\
2 & 3 & FP/46 & 10 & 71.939999 & 71.939999 & a \\
3 & 5 & FP/76 & 10 & 61.540000 & 61.540000 & ab \\
4 & 6 & FP/83 & 10 & 57.860000 & 57.860000 & abc \\
5 & 1 & FP/21 & 10 & 53.530000 & 53.530000 & bc \\
6 & 2 & FP/42 & 10 & 49.217998 & 49.217998 & bc \\
7 & 4 & FP/69 & 10 & 43.720001 & 43.720001 & c \\
\hline
\end{tabular}

Médias seguidas por letras distintas diferem entre si ao nivel de significância indicado.

D.M.S. $5 \%=17.28864$ 
Tabela 12: Análise da variância da Unidade enzimática total (Utotal) obtido pelas linhagens selvagens selecionadas FP/21, FP/42, FP/46, FP/69, FP/76, FP/83 e pela linhagem padrão FP/107, nos ensaios cinéticos realizados.

\begin{tabular}{lcccc}
\multicolumn{1}{c}{$\begin{array}{c}\text { Causas da } \\
\text { variaçåo }\end{array}$} & G.L. & S.Q. & Valor F & Prob. > F \\
\hline Li nhagem & 6. & 91707.0369681 & 29.5480 & 0.00001 \\
Tempo de fermentaçåo & 4 & 46409.1486033 & 22.4295 & 0.00001 \\
(TF) & & & & \\
Linhagem $\times$ TF & 24 & 49378.9874950 & 3.9775 & 0.00023 \\
Residuo & 35 & 18104.7192097 & - & - \\
Total & 69 & 205599.892276 & - & - \\
\hline Média geral $=54.700428$ & & Coeficiente de & variação $=41.57 \%$ & \\
\hline
\end{tabular}

Tabela 13: Teste de Tukey para os valores médios do parâmetro Utotal obtido pelas linhagens selvagens selecionadas FP/21, FP/42, FP/46, FP/69, FP/76, $\mathrm{FP} / 83$ e pela linhagem padrão $\mathrm{FP} / 107$, nos ensaios cinéticos realizados.

\begin{tabular}{ccccccc}
\hline $\begin{array}{c}\text { Número de } \\
\text { Ordem }\end{array}$ & $\begin{array}{c}\text { Número de } \\
\text { Tratamento }\end{array}$ & Nome & $\begin{array}{l}\text { Número de } \\
\text { repetiçă }\end{array}$ & Mëdias & $\begin{array}{l}\text { Médias } \\
\text { originais }\end{array}$ & $5 \%$ \\
\hline 1 & 6 & FP/83 & 10 & 134.700000 & 134.700000 & $\mathrm{a}$ \\
2 & 1 & FP/21 & 10 & 67.775000 & 67.775000 & $\mathrm{~b}$ \\
3 & 7 & FP/107 & $10^{-} \cdots$ & 57.135000 & 57.135000 & bc \\
4 & 4 & FP/69 & 10 & 44.975000 & 44.975000 & bcd \\
5 & 5 & FP/76 & 10 & 29.095000 & 29.095000 & cd \\
6 & 3 & FP/46 & 10 & 28.673000 & 28.673000 & cd \\
7 & 2 & FP/42 & 10 & 20.550000 & 20.550000 & d \\
\hline
\end{tabular}

Médias seguidas por letras distintas diferem entre si ao nível de significância indicado.

D.M.S. $5 \%=31.82549$ 


\subsection{Caracterização das linhagens selecionadas}

\subsubsection{Classificaçã̉o das linhagens}

As linhagens foram classificadas na Universidade Federal de Pernambuco, de acordo com o item (3.10.1.) da metodologia. Tais linhagens encontram-se abaixo relacionadas (Tabela 14).

Tabela 14: Classificação taxonômica dos isolados selvagens selecionados.

$N^{\circ}$ das Linhagens

Classificação

FP/21

Penicillium wasksmani Zaleski

$\mathrm{FP} / 42$

Aspergillus niger van Tieghem

$\mathrm{FP} / 46$

Aspergillus niger van Tieghem

FP/69

Aspergillus niger van Tieghem

FP/76

Aspergillus niger van Tieghem

FP/83

Trichoderma harzianum Rifai

Todos os gêneros encontrados, descritos acima, têm sido relatados como produtores de pectinase (PARK, 1972; FOGARTY \& KELLY, 1983). Entretanto, o gênero Aspergillus tem sido o mais utilizado para preparaçōes de enzimas pécticas industriais, provavelmente por possuir aprovação para uso na indústria de alimentos. 


\subsubsection{Caracterização citológica das linhagens}

As linhagens foram caracterizadas citologicamente pela técnica de coloração de núcleos, estimando o número de núcleos por esporos (item 3.10.2). Foram analisados 500 conidios por linhagem, cujos resultados encontram-se sumarizados na Tabela 15. Nesta, observa-se que somente as linhagens FP/21 e FP/83, apresentaram conídios 100\% uninucleados. A obtenção de linhagens com esporos uninucleados constitui-se de um material propício para futuros estudos genéticos, uma vez que a obtenção e seleção de mutantes é facilitada a partir de conídios uninucleados (PONTECORVO et. al., 1953).

Tabela 15: Freqüência de núcleos por conidios das linhagens selvagens selecionadas.

$\%$ de núcleos por conídios

\begin{tabular}{lrrrrrr}
\hline Linhagem & Uni & $\mathrm{Bi}$ & Tri & Tetra & Penta & Multinucleados \\
\hline FP/21 & 100,0 & & & & & \\
FP/42 & 42,6 & 57,4 & & & & \\
FP/46 & 67,4 & 32,6 & & & & \\
FP/69 & 78,2 & 19,2 & 1,2 & 1,4 & & \\
FP/76 & 54,2 & 44,0 & 1,2 & 0,6 & & \\
FP/83 & 100,0 & & & & & \\
FP/107 & & 4,0 & 23,2 & 37,0 & 25,0 & \\
\hline
\end{tabular}

Através das Figuras 9 e 10, apresentadas a seguir, podem ser observadas as características morfológicas apresentadas pelos conídios de cada uma das linhagens selvagens selecionadas. 


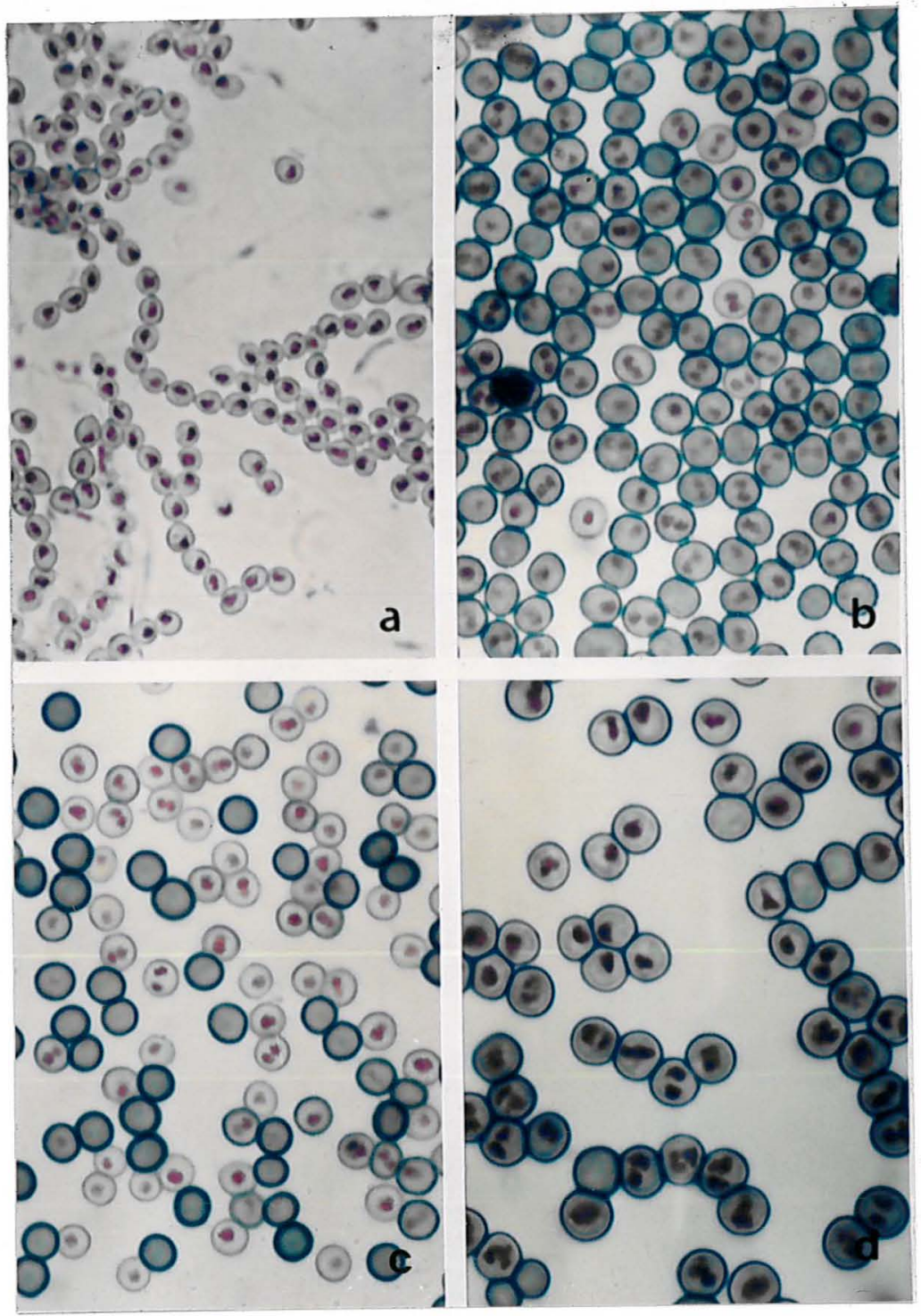

Figura 9 - Linhagem FP/21 - conídios ovais uninucleados, normalmente em forma de correntes e núcleos bem acentuados (a); Linhagem FP/42 - conídios redondos de parede ornamentada, uni e binucleados (b); Linhagem FP/46 conidios redondos, uni e binucleados (c); Linhagem FP/69 - conídios redondos irregulares, uni e binucleados (d). Aumento de 1.500x. 


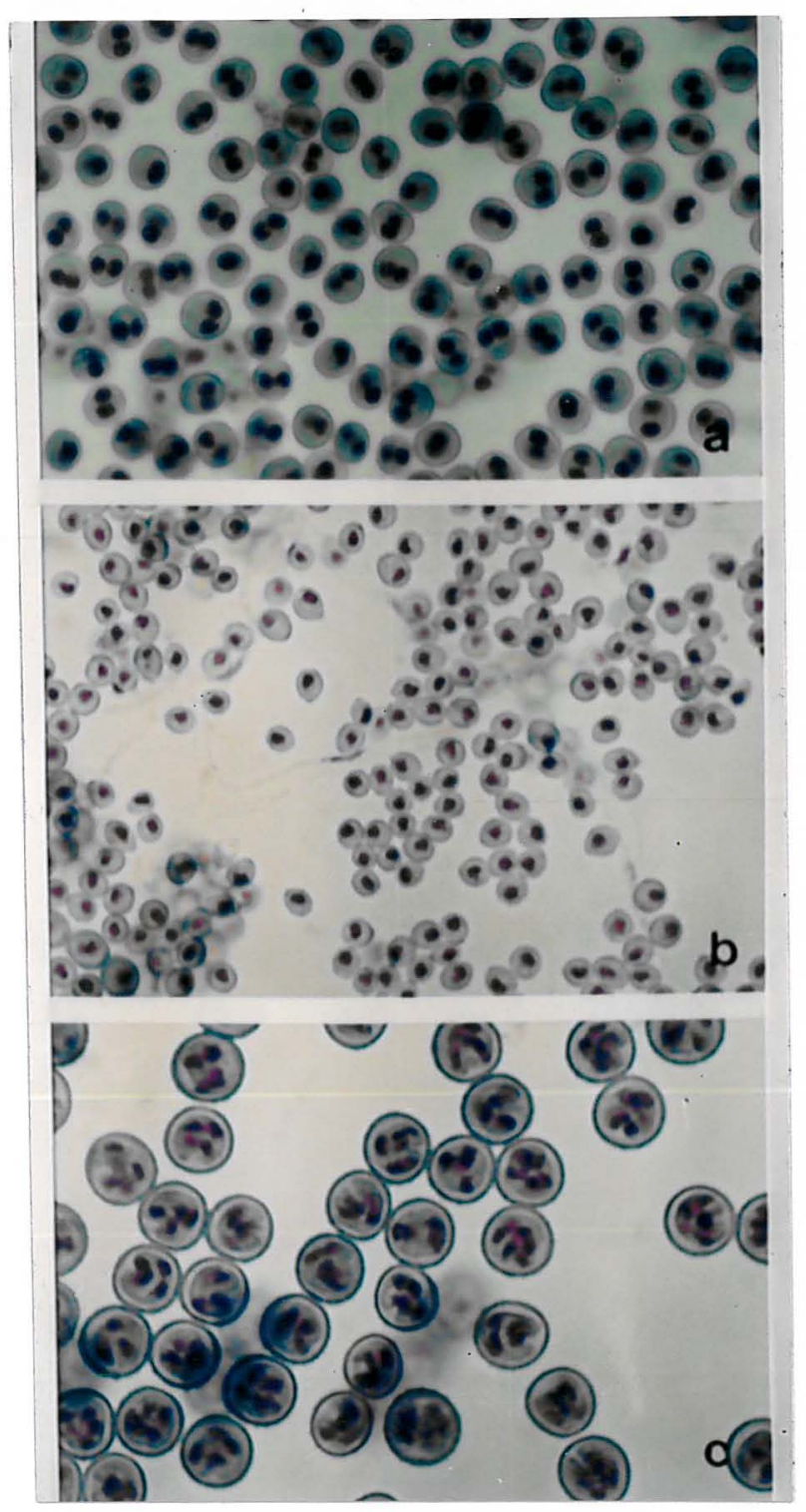

Figura 10 - Linhagem FP/76 - conídios redondos, uni e binucleados (a); Linhagem FP/83 - conídios ovais uninucleados, núcleos acentuados, (b); Linhagem FP/107 - conídios grandes multinuclear arredondados, e de parede levemente ornamentada, (c); Aumento de 1500x. 


\subsection{Determinação da redução de colónia pelo emprego de desoxicolato de sódio}

A linhagem selecionada como mais promissora quanto à produção de pectinases foi classificada como Trichoderma harzianum Rifai (FP/83), possui um rápido crescimento, que é característico para esse gênero (BISSETT, 1984). Fez-se necessária a determinação da concentração adequada de desoxicolato de sódio para que, com a redução no tamanho da colônia, fosse possivel observar um maior número de colônias em sua forma individualizada em uma única placa, facilitando assim o acompanhamento da sobrevivência dos conídios, quando expostos à luz ultravioleta.

A Tabela 16 mostra a redução do diâmetro das colônias por desoxicolato de sódio, em meio completo, ao longo do tempo e em função da concentração empregada para desoxicolato de sódio. Nesta Tabela observase que 0 crescimento reduziu-se consideravelmente na presença do desoxicolato de sódio, sendo o efeito da inibição diretamente proporcional à concentração usada. Em concentrações entre 0,1\% e 0,2\%, obteve-se redução suficiente para individualização de colônias, selecionando-se a concentração de $0,1 \%$ desta solução redutora a continuidade dos trabalhos.

Tabela 16: Redução do diâmetro de colônias de Trichoderma harzianum Rifai, crescidas em meio completo (os dados constituem média de três repetiçōes, e estão expressos em cm).

\begin{tabular}{|c|c|c|c|c|c|}
\hline $\begin{array}{c}\text { Concentra- } \\
\text { cāo }(\%)\end{array}$ & & & EMPO & (HORAS) & \\
\hline & 24 & 48 & 72 & 96 & 120 \\
\hline $\begin{array}{l}0,0 \\
0,1 \\
0,2 \\
0,3\end{array}$ & $\begin{array}{c}2,50 \\
0,45 \\
0,37 \\
-\end{array}$ & $\begin{array}{l}3,40 \\
0,58 \\
0,50 \\
0,30\end{array}$ & $\begin{array}{l}5,00 \\
1,00 \\
0,80 \\
0,52\end{array}$ & $\begin{array}{l}7,70 \\
1,60 \\
1,27 \\
0,93\end{array}$ & $\begin{array}{l}9,00 \\
1,97 \\
1,53 \\
1,00\end{array}$ \\
\hline
\end{tabular}

O desoxicolato de sódio têm sido utilizado com sucesso na obtenção de colônias isoladas de espécies do gênero Trichoderma (SCHIMENTI et al., 1983; ZALDIVAR et al.; 1987 e CARVALHO (1989), e de 
outros fungos filamentosos (HANKIN \& ANAGNOSTAKIS, 1977). CARVALHO, 1989, analisou o efeito de desoxicolato de sódio sobre o diâmetro das colônias e observou o desenvolvimento micelial e conidiação em Trichoderma reesei QM 9414 e Trichoderma sp., determinando neste caso a utilização de $0,5 \%$ de redutor em todos os ensaios. Constatou ainda, que esta substância redutora atua a nivel de metabolismo primário retardando o desenvolvimento de hifas e a formação de conidios. $\mathrm{Na}$ presença do redutor, observou também a ocorrência de clamidosporos, em Trichoderma sp, após 72 horas de incubação.

Comparativamente, aos resultados de CARVALHO (1989), a linhagem $T$. harzianum Rifai FP/83 isolada neste trabalho, mostrou-se mais sensivel ao efeito redutor do desoxicolato de sódio, reduzindo o tamanho da colônia a cerca de 10 vezes em relação ao controle quando $0,3 \%$ desse redutor foi utilizado. Estes resultados demonstram que, embora o modo de ação deste redutor possa ser semelhante em ambos os casos, as particularidades e sensibilidade de cada linhagem devem ser investigadas, para se evitar o uso de concentrações inadequadas e possivelmente deletérias do mesmo.

\subsection{Sobrevivência à luz ultravioleta}

A linhagem selecionada FP/83 (Trichoderma harzianum Rifal) não pertence ao gênero mais aceito na produção de pectinases para utilização na indústria de alimentos, entretanto foi verificado que tal linhagem não é produtora de aflatoxinas. O teste foi realizado pelo Instituto de Ciências Biomédicas da Universidade de São Paulo, no Departamento de Microbiologia, Seção de Micologia, segundo o método descrito por LIN \& DIANASE (1970). Este resultado foi importante, pois, de certo modo, tranqüiliza as posteriores manipulaçōes com tal linhagem.

A linhagem selecionada foi avaliada quanto à sua sobrevivência ao mutagênico luz ultravioleta, estabelecendo-se uma curva de sobrevivência para a obtenção de mutantes visando futuros estudos genéticos. A luz ultravioleta tem sido utilizada com sucesso na obtenção de mutantes de espécies do gênero Trichoderma (TOYAMA et al., 1984; KAWAMORI et al., 1985; CARVALHO, 1989). 
Suspensões de conidios de Trichoderma harzianum Rifai (FP/83) foram irradiados com luz ultravioleta, de acordo com o item (3.9.5.). A Tabela 17 e Figura 11 mostram os dados referentes à porcentagem e curva de sobrevivência, respectivamente. A porcentagem de sobrevivência em torno de $5 \%$ foi obtida aos 4 minutos e 45 segundos de tratamento. A linhagem apresentou grande susceptibilidade à luz ultravioleta, evidenciada pela redução acentuada de células viáveis/ml no decorrer do tratamento.

Tabela 17: Porcentagem de sobreviência dos conidios de Trichoderma harzianum Rifai após exposição à luz ultravioleta (os dados constituem média de três repetições).

\begin{tabular}{ccc}
\hline Tempo (minutos) & Conídios viáveis/ml & \% relativa de sobrevivência \\
\hline 0 & $2,20 \times 10^{6}$ & 100 \\
T2 & $1,85 \times 10^{6}$ & 84.09 \\
T3 & $1,20 \times 10^{5}$ & 54.55 \\
T4 & $4,30 \times 10^{5}$ & 19.55 \\
T5 & $3,75 \times 10^{5}$ & 1.70 \\
T6 & $2,33 \times 10^{4}$ & 1.06 \\
\hline
\end{tabular}

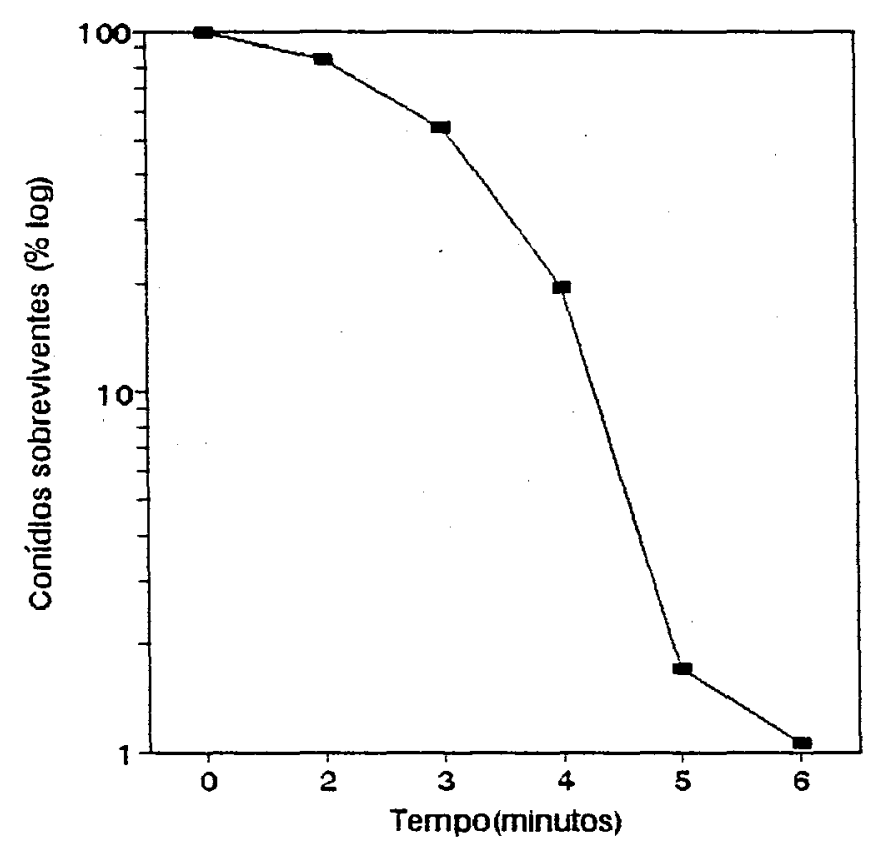

Figura 11 - Curva de sobrevivência dos conídios da linhagem de Trichoderma harzianum Rifai (FP/83) após exposição à luz ultravioleta. 
Segundo AZEVEDO (1985), a resposta a um tratamento mutagênico se deve principalmente ao grau de pigmentação, ao número de núcleos por conidio e quantidade de DNA existente no material genético. GOLDMAN (1988) relatou para $A$. niger uma resistência à exposição de luz ultravioleta relacionada com a presença de conídios com pigmentação escura. O tempo de tratamento para obtenção de $5 \%$ de sobrevivência de conídios da linhagem de $T$. harzianum Rifai (FP/83), foi bem inferior àquele obtido para Humicola sp (RODRIGUES, 1987) e Aspergillus niger (GOLDMAN, 1988), mas superior em relação a outros fungos como Aspergillus sp. (PEREIRA, 1978), Metarhizium anisopliae (BAGALHI, 1987) e Boveria bassianica (PACCOLAMEIRELLES, 1988). Embora a linhagem de Trichoderma harzianum Rifai apresente conidios pigmentados (RIFAl, 1969), o que dificultaria a penetração da luz ultravioleta, estes são uninucleados, o que poderia explicar valores intermediários de tratamento, em relação a outros fungos. Entretanto, esta hipótese não pode se considerada isoladamente, pois apesar do tempo de exposição ser um dado importante, torna-se incompleto quando este não esta associado a potência (nivel de energia) da luz de ultravioleta que foi utilizada.

\subsubsection{Obtenção de mutantes morfológicos}

Após a curva de sobrevivência, foram isolados os mutantes morfológicos encontrados no tempo de 4 minutos e 45 segundos, conforme indicado no item (3.9.5.). Na Tabela 18 encontram-se sumarizados os 20 mutantes obtidos entre as 250 colônias analisadas, bem como suas respectivas características, observando-se sete mutantes de coloraçāo branca, três de coloração marron, um de coloração amarela e nove de coloração verde com morfologia alterada em relação a seu parental. 
Tabela 18: Mutantes morfológicos resultantes do tratamento de conídios da linhagem Trichoderma harzianum Rifai (FP/83), com luz ultravioleta, no tempo de exposição de 4 minutos e 45 segundos.

\begin{tabular}{cl}
\hline Número de Mutantes Morfológicos & \multicolumn{1}{c}{ Características Morfológicas } \\
\hline $1(1 / 4)$ & colônia verde compactada \\
$2(1 / 8)$ & colônia branca \\
$3(1 / 9)$ & colônia branca \\
$4(1 / 14)$ & colónia branca \\
$5(1 / 15)$ & colônia branca \\
$6(1 / 19)$ & colônia branca \\
$7(2 / 3)$ & colônia marrom \\
$8(2 / 19)$ & colônia branca \\
$9(2 / 25)$ & colônia marrom \\
$10(4 / 8)$ & colônia verde compactada \\
$11(5 / 19)$ & colônia verde compactada \\
$12(6 / 1)$ & colônia branca \\
$13(6 / 17)$ & colônia verde compactada \\
$14(7 / 2)$ & colônia verde compactada \\
$15(7 / 7)$ & colônia marrom \\
$16(7 / 13)$ & colônia amarela \\
$17(7 / 14)$ & colônia verde compactada \\
$18(8 / 14)$ & colônia verde compactada \\
$19(10 / 7)$ & colónia verde compactada \\
$20(10 / 9)$ & colônia verde alterada c/redução de \\
FP $/ 83($ parental) & conidiaçäo \\
& colônia verde \\
\hline
\end{tabular}

\subsection{Seleção dos mutantes em cultura submersa}

Após a mutagênese, todos os mutantes encontrados (20 variantes morfológicos) passaram pela seleção em cultura submersa conforme item (3.7), por ter sido indicado inicialmente como método muito eficaz, embora mais demorado, na seleção de linhagens promissoras na produção desse complexo enzimático, nas condiçōes testadas.

Pela análise dos resultados (tabela 19), nota-se que 14 variantes morfológicos representando $70 \%$ do total dos mutantes isolados apresentaram valores de atividade total em torno de 2 a 2,5 vezes maior que seu parental. Cerca de $10 \%$ dos variantes morfológicos avaliados mantiveram sua produção enzimática a níveis parecidos e $20 \%$ produziram bem menos. 
Além disso, observa-se ainda pela Tabela 19 que houve uma grande homogeneidade nos niveis de $\mathrm{pH}$ final obtidos para as linhagens mutantes testadas. O mesmo não foi observado durante a seleção dos isolados selvagens (Tabela 6), o que talvez seja explicado devido a grande variabilidade existente entre esses isolados. A manutenção do $\mathrm{pH}$ a niveis baixos e próximos dos valores a que foram tamponados $(\mathrm{pH}=3.5)$, é bastante interessante pois tal faixa de $\mathrm{pH}$ tem sido indicada com excelente para a biossintese das enzimas pectinolíticas (FUMIAN, 1987).

Por outro lado, o desenvolvimento celular acompanhado pela medida de massa seca não apresentou a mesma homogeneidade observada para medida de $\mathrm{pH}$ final. $\mathrm{Na}$ Tabela 19 observa-se que cerca de $50 \%$ dos mutantes tiveram um desenvolvimento celular inferior ao que foi obtido pela linhagem parental (FP/83). Entretanto este dado parece não estar refletindo diretamente na capacidade secretora desses mutantes, pois uma linhagem mutante como por exemplo a 10/7, com valor de biomassa inferior a seu parental, foi capaz de secretar niveis enzimáticos ligeiramente superior a este.

Tais resultados talvez sejam explicados devido a possiveis alteraçōes na parede celular desses variantes provocadas quando os conídios de origem foram expostos à luz ultravioleta, possibilitando assim uma maior facilidade na secreção de enzimas. Esta hipótese tem sido levantada por diferentes autores. GRATZNER (1972) descreveu um mutante de Neurospora crassa, com alteraçōes na parede celular associadas com hiperprodução de enzimas extracelulares. MORAYAMA \& TSHIKAWA (1973) obtiveram mutantes com alteraçōes simultâneas de atividades exoenzimáticas e de crescimento.

A partir desta seleção, apesar de muitos variantes morfológicos terem se sobressaído ao seu parental quanto à capacidade aumentada na produção do complexo enzimático em foco neste trabalho, foram escolhidos apenas 5 mutantes morfológicos para que as cinéticas enzimáticas comparativas com o parental fossem realizadas. Tais linhagens exibiram os maiores valores de Utotal comparados a linhagem parental FP/83, que foi de 140,00 Utotal; sendo estas: $1 / 4,1 / 9,2 / 3,5 / 19$ e 6/1, com valores de Utotal de 297,$13 ; 310,00 ; 202,38 ; 205,02$ e 213,60 , respectivamente. 
Tabela 19: Seleção em cultura submersa dos mutantes morfológicos provenientes da linhagem de Trichoderma harzianum Rifai FP/83 (medidas de atividade enzimática no tempo 72 horas)

\begin{tabular}{|c|c|c|c|c|c|}
\hline Linhagem & $\mathrm{U} / \mathrm{ml}$ & $\begin{array}{l}\mathrm{U} / \text { total } \\
\mathrm{U} \times 50 \mathrm{ml}\end{array}$ & $\begin{array}{c}\text { Uesp. } \\
\text { (U total / mg } \\
\text { M. seca) }\end{array}$ & $\begin{array}{c}\text { M.seca } \\
\text { (mg) }\end{array}$ & pH Final \\
\hline $1 / 4$ & 5.54 & 297.13 & 5.714 .04 & 52,00 & 3.58 \\
\hline $1 / 8$ & 2.74 & 136.84 & 3.138 .53 & 43,60 & 3.47 \\
\hline $1 / 9$ & 6.20 & 310.00 & 4.783 .95 & 64,80 & 3.62 \\
\hline $1 / 14$ & 3.98 & 198.97 & 3.153 .25 & 63,10 & 3.56 \\
\hline $1 / 15$ & 3.53 & 176.46 & 3.095 .79 & 57,00 & 3.48 \\
\hline $1 / 19$ & 2.83 & 141.39 & 2.827 .80 & 50,00 & 3.52 \\
\hline $2 / 3$ & 4.05 & 202.38 & 3.172 .10 & 63,80 & 3.44 \\
\hline $2 / 19$ & 3.24 & 161.80 & 2.889 .29 & 56,00 & 3.45 \\
\hline $2 / 25$ & 3.25 & 161.55 & 2.802 .59 & 58,00 & 3.50 \\
\hline $4 / 8$ & 1.88 & 95.00 & 1.413 .53 & 66,50 & 3.51 \\
\hline $5 / 19$ & 4.10 & 205.02 & 2.642 .01 & 77,60 & 3.72 \\
\hline $6 / 1$ & 4.27 & 213.60 & 3.064 .53 & 63,70 & 3.54 \\
\hline $6 / 17$ & 2.64 & 132.14 & 1.512 .30 & 69,10 & 3.48 \\
\hline $7 / 2$ & 3.01 & 150.74 & 2.233 .18 & 67,50 & 3.70 \\
\hline $7 / 7$ & 3.10 & 154.98 & 2.685 .56 & 57,70 & 3.5 \\
\hline $7 / 13$ & 1.05 & 54.72 & 1.169 .23 & 46,80 & 3.58 \\
\hline $7 / 14$ & 3.11 & 155.65 & 2.048 .03 & 76,00 & 3.49 \\
\hline $8 / 14$ & 1.03 & 51.67 & 1.048 .07 & 49,30 & 3.63 \\
\hline $10 / 7$ & 3.33 & 166.55 & 4.237 .91 & 39,30 & 3.56 \\
\hline $10 / 9$ & 1.09 & 54.35 & 1.489 .04 & 36,50 & 3.54 \\
\hline FP/83 & 2.80 & 140.00 & 2.337 .23 & 59,90 & 3.46 \\
\hline
\end{tabular}




\subsection{Cinética de crescimento com avaliação da atividade enzimática dos mutantes selecionados}

Foram selecionados 5 mutantes morfológicos: 1/4, 1/9, 2/3, 5/19 e 6/1, para realização das cinéticas. Entretanto, apenas 4 desenvolveram-se adequadamente para condução do referido ensaio: 1/4, 1/9, 2/3 e 6/1, a linhagem mutante $5 / 19$ não se desenvolveu satisfatoriamente, tendo sido descartada posteriormente. Conduziu-se a fermentação de modo semelhante ao apontado no item (3.8).

A Tabela 20 apresenta os resultados obtidos. A dispersão entre os valores de atividades foi a mesma que aquela encontrada na cinética dos selvagens mais promissores. Novamente verificaram-se valores extremamente altos de desvio padrão para as medidas de atividade enzimática (Utotal), principaimente para os mutantes após o tempo de 72 horas de fermentação, sendo que a linhagem parental Trichoderma harzianum Rifai (FP/83) foi a que apresentou a menor dispersão. Talvez esta apresente maior estabilidade frente a seus mutantes, sofrendo menor alteração com as possiveis mudanças ambientais. Nota-se também na Tabela 20 , que os valores de biomassa parecem semelhantes para os mutantes $1 / 9 ; 2 / 3$ e $6 / 1$ e apresentam uma dispersāo maior que seu parental FP/83. O mutante $1 / 4$ apresenta niveis de biomassa e dispersão em geral mais baixos que os demais mutantes. Verificase também que, de modo geral, a máxima produção de biomassa coincide com a máxima atividade enzimática.

Tais resultados diferem daqueles apresentados por ANGELOVA (1986) que, estudando a produção de enzimas pectinolíticas em cultura submersa por Aspergillus niger, observou que o valor máximo de acúmulo de biomassa não coincide com a máxima de biossíntese de polimetigalacturonase. O mais alto acúmulo de biomassa foi observado a 32 horas enquanto o máximo de formação de enzima ocorreu a 72 horas. Segundo o autor, estes resultados podem indicar uma síntese residual em polimetigalacturonase, que pode ser devida a alta estabilidade do RNA desta enzima. Esta estabilidade foi confirmada por experimentos com actinomicina $D$. A enzima continuou a ser formada mesmo depois da transcrição bloqueada. 
TABELA 20: Dados da cinética de crescimento com avaliação da atividade pectinolítica dos mutantes morfológicos selecionados, comparados ao parental $\mathrm{FP} / 83$. Os valores representam a média de três experimentos independentes e seu desvio padrão.

\begin{tabular}{|c|c|c|c|c|c|}
\hline Linhagem & $\begin{array}{l}\text { Tempo de } \\
\text { Fermenta- } \\
\text { cão }(h)\end{array}$ & $\mathrm{U} / \mathrm{ml}$ & $\begin{array}{l}U \text { total } \\
U / 50 \mathrm{ml}\end{array}$ & $\begin{array}{c}\text { Massa seca } \\
\quad(\mathrm{mg})\end{array}$ & $\mathrm{pH}$ \\
\hline \multirow{5}{*}{$1 / 4$} & 24 & $0.11 \pm 0.08$ & $5.72 \pm 4.18$ & $30.17 \pm 8.35$ & 3.65 \\
\hline & 48 & $2.07 \pm 0.23$ & $103.73 \pm 1.45$ & $45.30 \pm 9.87$ & 3.59 \\
\hline & 72 & $5.11 \pm 2.38$ & $255.47 \pm 18.96$ & $51.03 \pm 5.55$ & 3.64 \\
\hline & 96 & $7.47 \pm 2.61$ & $573.37 \pm 130.39$ & $57.43 \pm 9.43$ & 3.73 \\
\hline & 120 & $8.10 \pm 2.17$ & $405.09 \pm 108.68$ & $57.50 \pm 2.43$ & 3.86 \\
\hline \multirow{5}{*}{$1 / 9$} & 24 & $0.30 \pm 0.32$ & $15.24 \pm 16.10$ & $34.73 \pm 11.64$ & 3.82 \\
\hline & 48 & $1.48 \pm 0.38$ & $73.82 \pm 19.13$ & $44.30 \pm 11.55$ & 3.62 \\
\hline & 72 & $1.70 \pm 1.02$ & $146.23 \pm 50.83$ & $53.33 \pm 11.55$ & 3.72 \\
\hline & 96 & $3.89 \pm 1.25$ & $194.46 \pm 62.73$ & $64.73 \pm 12.95$ & 3.85 \\
\hline & 120 & $5.79 \pm 2.82$ & $284.33 \pm 141.22$ & $65.90 \pm 8.88$ & 4.12 \\
\hline \multirow{5}{*}{$2 / 3$} & 24 & $0.22 \pm 0.25$ & $11.10 \pm 12.63$ & $31.73 \pm 11.64$ & 3.72 \\
\hline & 48 & $1.35 \pm 0.71$ & $67.61 \pm 35.55$ & $44.30 \pm 11.55$ & 3.57 \\
\hline & 72 & $2.36 \pm 1.13$ & $117.90 \pm 56.68$ & $53.33 \pm 11.55$ & 3.64 \\
\hline & 96 & $3.47 \pm 1.96$ & $173.45 \pm 98.09$ & $64.73 \pm 12.95$ & 3.73 \\
\hline & 120 & $4.27 \pm 2.81$ & $213.51 \pm 140.61$ & $65.90 \pm 8.88$ & 3.93 \\
\hline \multirow{5}{*}{$6 / 1$} & 24 & $0.19 \pm 0.11$ & $9.72 \pm 5.72$ & $32.53 \pm 10.34$ & 3.80 \\
\hline & 48 & $1.21 \pm 0.57$ & $60.30 \pm 28.61$ & $48.83 \pm 16.57$ & 3.58 \\
\hline & 72 & $2.01 \pm 0.68$ & $100.70 \pm 34.10$ & $55.20 \pm 8.91$ & 3.63 \\
\hline & 96 & $3.09 \pm 1.29$ & $154.62 \pm 64.56$ & $62.93 \pm 14.89$ & 3.76 \\
\hline & 120 & $4.54 \pm 3.02$ & $226.81 \pm 150.90$ & $67.10 \pm 5.66$ & 3.84 \\
\hline \multirow{5}{*}{$\begin{array}{c}\text { FP/83 } \\
\text { (Parental) }\end{array}$} & 24 & $0.21 \pm 0.16$ & $10.64 \pm 7.98$ & $30.00 \pm 3.82$ & 3.60 \\
\hline & 48 & $1.82 \pm 0.11$ & $91.00 \pm 5.66$ & $46.90 \pm 1.77$ & 3.59 \\
\hline & 72 & $3.00 \pm 0.28$ & $150.00 \pm 14.14$ & $53.50 \pm 8.70$ & 3.64 \\
\hline & 96 & $4.01 \pm 0.30$ & $200.50 \pm 14.85$ & $59.00 \pm .6 .86$ & 3.77 \\
\hline & 120 & $5.50 \pm 0.42$ & $274.87 \pm 21.04$ & $69.60 \pm 8.56$ & 3.80 \\
\hline
\end{tabular}

Os valores de atividade enzimática no ensaio cinético, também não reproduziram os obtidos na seleção em cultura submersa (Tabela 19) para os mutantes $1 / 9,2 / 3$ e 6/1, a exemplo do que ocorreu durante a seleção dos isolados selvagens. Tal metodologia não está isenta de falhas, já que podem existir casos onde as linhagens apresentem atividades enzimática máximas na fase estacionária (GACESA \& HUBBLE, ([198-]). Dessa forma a comparação entre linhagens, através da medida de atividade enzimática em único tempo de fermentação pode ser arriscada.

Contudo, sabe-se que, de maneira geral, a enzima é sintetizada durante parte do ciclo de crescimento, ou seja, algumas proteinas são 
sintetizadas e secretadas durante a fase exponencial de crescimento (GACESA \& RUBBLE ([198-]).

Portanto, supôs-se que o tempo de fermentação utilizado (72 horas), estivesse, para a maioria dos isolados, entre as fases exponencial e estacionária, já que muitos autores utilizam este tempo de fermentação para tomada de amostras e respectivas medidas enzimáticas (HUANG, 1988; FRIESE, 1987).

Pela Tabela $20^{\circ}$, observa-se a superioridade do mutante $1 / 4 \mathrm{com}$ atividades cerca de 2 vezes maior, após 72 horas de fermentação, que a apresentada pelo seu parental (FP/83). Nota-se ainda que, seus resultados apresentaram-se reprodutiveis frente aos valores obtidos na seleção em cultura submersa. Estes dados podem ser melhor observados pela Figura 12, pois a superioridade da linhagem mutante $1 / 4$ é destacada tanto frente ao seu parental FP/83 quanto a linhagem padrão FP/107. Nesta verifica-se também que até o maior tempo de fermentação avaliado (120 horas), não ocorre um declíneo na produção enzimática. Entretanto, a produção de massa celular observada na Tabela 20 , parece indicar que a maioria das linhagens se encontram numa fase estacionária de crescimento.

Os resultados contidos na Tabela 20 foram submetidos a uma análise de variância (Tabela 21). Através desta constata-se que realmente a variável massa celular seca não apresenta diferenças significativas entre os resultados obtidos para os mutantes, o que foi comprovado pelo teste de Tukey (Tabela 22). Pela Tabela 23 observa-se que para a variável Utotal, houve diferenças significativas entre as linhagens, pelo teste de Tukey nota-se que a diferença existe apenas entre a linhagem mutante $1 / 4 \mathrm{e}$ as demais $1 / 9,2 / 3 \mathrm{e}$ $6 / 1$ e a parental FP/83. Para estas últimas não se observa nenhuma diferença ao nivel de significância indicado (Tabela 24). 


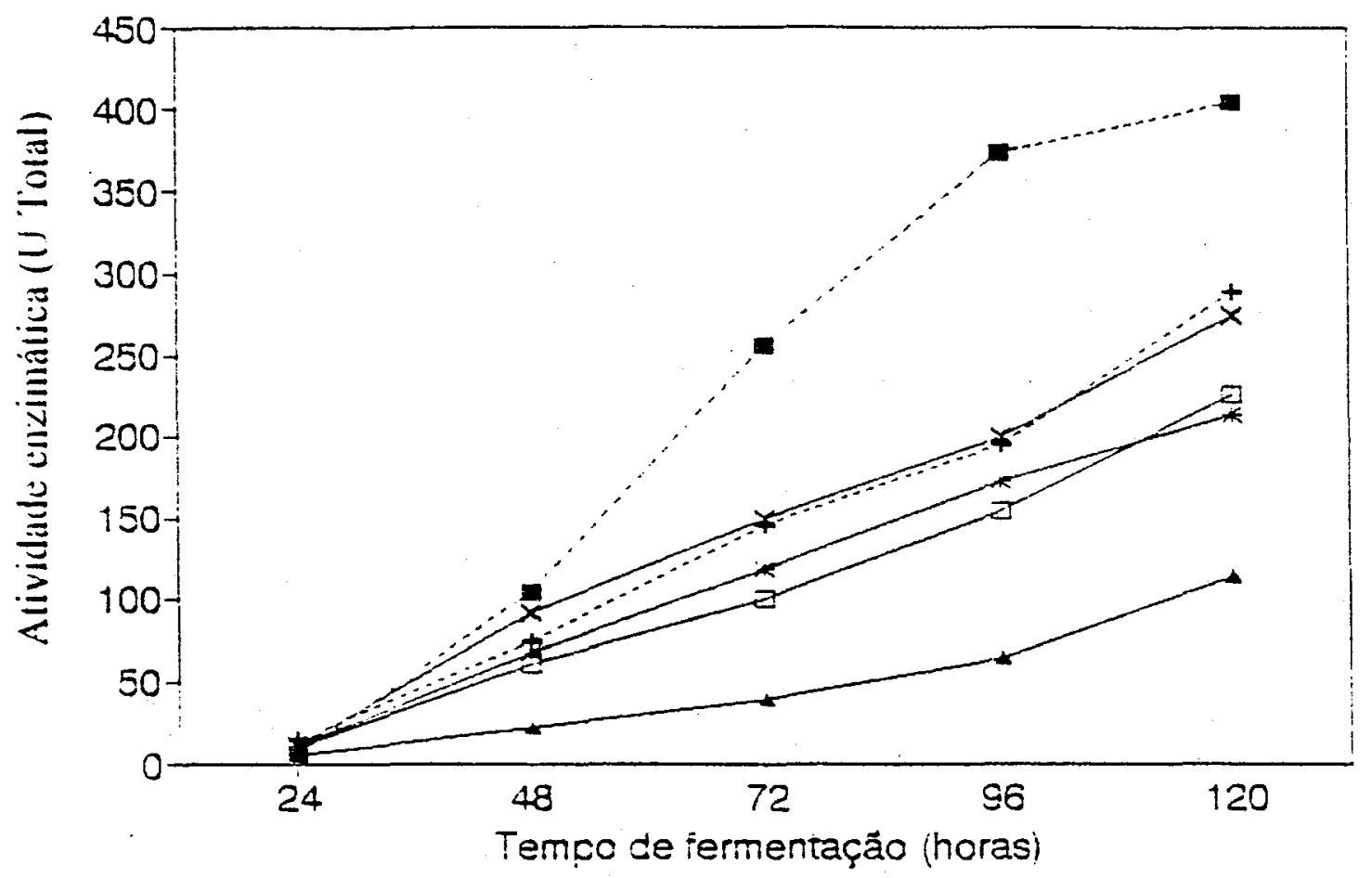

Figura 12 - Cinéticas de crescimento com avaliação da atividade enzimática dos mutantes morfológicos selecionados, comparadas ao parental (FP/83) e a linhagem padrāo (FP/107). 
Tabela 21: Análise de variância da massa celular seca $(\mathrm{mg})$ obtida pelas linhagens mutantes selecionadas $1 / 4,1 / 9,2 / 3,6 / 1$ e pela linhagem parental FP/83, nos ensaios cinéticos realizados.

\begin{tabular}{lcccc}
\hline \multicolumn{1}{c}{$\begin{array}{c}\text { Causas da } \\
\text { variação }\end{array}$} & G.L. & S.Q. & Valor $F$ & Prob. $>$ F \\
\hline Linhagem & 4 & 1098.8089227 & 2.2575 & 0.07518 \\
Tempo de fermentação & 4 & 9331.6805581 & 19.1717 & 0.00001 \\
(TF) & & & & \\
Linhagem $\times$ TF & 16 & 1224.6276048 & 0.6290 & 0.84506 \\
Residuo & 50 & 6084.2704049 & - & - \\
Total & 74 & 17739.3874904 & - & - \\
\hline Média geral $=53.409599$ & & Coeficiente de variação $=20.65 \%$ & \\
\hline
\end{tabular}

Tabela 22: Teste de Tukey para os valores médios da massa celular seca (mg) obtida pelas linhagens mutantes selecionadas $1 / 4,1 / 9,2 / 3,6 / 1$ e pela linhagem parental FP/83, nos ensaios cinéticos realizados.

\begin{tabular}{ccccccc}
\hline $\begin{array}{c}\text { Número de } \\
\text { Ordem }\end{array}$ & $\begin{array}{c}\text { Número de } \\
\text { Tratamento }\end{array}$ & Nome & $\begin{array}{c}\text { Número de } \\
\text { repetiçảo }\end{array}$ & Mëdias & $\begin{array}{l}\text { Médias } \\
\text { originais }\end{array}$ & $5 \%$ \\
\hline 1 & 5 & FP/83 & 15 & 59.380001 & 59.380001 & a \\
2 & 3 & $2 / 3$ & 15 & 54.153334 & 54.153334 & ab \\
3 & 2 & $1 / 9$ & $15 \ldots$ & 53.193333 & 53.193333 & ab \\
4 & 4 & $6 / 1$ & 15 & 52.980000 & 52.980000 & ab \\
5 & 1 & $1 / 4$ & 15 & 47.341332 & 47.341332 & b \\
\hline
\end{tabular}

Médias seguidas por letras distintas diferem entre si ao nivel de significância indicado.

D.M.S. $5 \%=11.42136$ 
Tabela 23: Análise de variância da Unidade enzimática total (Utotal) obtida pelas linhagens mutantes selecionadas $1 / 4,1 / 9,2 / 3,6 / 1$ e pela linhagem parental FP/83, nos ensaios cinéticos realizados.

\begin{tabular}{lcccc}
\hline \multicolumn{1}{c}{$\begin{array}{c}\text { Causas da } \\
\text { variaçåo }\end{array}$} & G.L. & S.Q. & Valor F & Prob. > F \\
\hline $\begin{array}{l}\text { Linhagem } \\
\text { Tempo de fermentação }\end{array}$ & 4 & 142882.6071202 & 8.5952 & 0.00009 \\
(TF) & & 647404.9664147 & 38.9452 & 0.00001 \\
Linhagem $\times$ TF & 16 & 84412.8504130 & 1.2695 & 0.25301 \\
Residuo & 50 & 207793.6000415 & - & - \\
Total & 74 & 1082494.023989 & - & - \\
\hline Média geral $=147.949203$ & & Coeficiente de variação $=43.57 \%$ & \\
\hline
\end{tabular}

Tabela 24: Teste de Tukey para os valores médios do parâmetro Utotal obtido pelas linhagens mutantes selecionadas $1 / 4,1 / 9,2 / 3,6 / 1$ e pela linhagem parental FP/83, nos ensaios cinéticos realizados.

\begin{tabular}{ccccccc}
\hline $\begin{array}{l}\text { Número de } \\
\text { Ordem }\end{array}$ & $\begin{array}{l}\text { Número de } \\
\text { Tratamento }\end{array}$ & Nome & $\begin{array}{l}\text { Número de } \\
\text { repetiçåo }\end{array}$ & Médias & $\begin{array}{l}\text { Médias } \\
\text { originais }\end{array}$ & $5 \%$ \\
\hline 1 & 1 & $1 / 4$ & 15 & 228.617337 & 228.617337 & $\mathrm{a}$ \\
2 & 5 & $\mathrm{FP} / 83$ & 15 & 156.765328 & 156.765328 & $\mathrm{~b}$ \\
3 & 2 & $1 / 9$ & 15 & 130.549332 & 130.549332 & $\mathrm{~b}$ \\
4 & 3 & $2 / 3$ & 15 & 116.356670 & 116.356670 & $\mathrm{~b}$ \\
5 & 4 & $6 / 1$ & 15 & 107.457333 & 107.457333 & $\mathrm{~b}$ \\
\hline
\end{tabular}

Médias seguidas por letras distintas diferem entre si ao nivel de significancia indicado.

D.M.S. $5 \%=66.74670$ 
Para efeito comparativo entre as linhagens selvagens, mutantes e a linhagem referência, foi conduzida uma análise onde os parâmetros utilizados para avaliação durante a seleção em cultura submersa, assim como nos ensaios cinéticos entre as linhagens selvagens e mutantes mais promissoras, ou seja, as caracteristicas de cada linhagem avaliada através de sua massa celular seca (MS) e unidade enzimática total (Utotal), foram analisados seguindo um experimento fatorial em blocos casualizados, onde as linhagens padrão (FP/107), a parental (FP/83) e seus mutantes (1/4, 1/9,2/3 e 6/1) foram analisados juntamente com mais duas linhagens selvagens selecionadas previamente (FP/21) e (FP/69), dando um total de 8 niveis para o fator fungo. Os resultados obtidos constam das tabelas 25 e 26,27 e 28 , e 29 e 30 , as quais apresentam respectivamente o quadro da análise de variância e o teste de Tukey para as médias de cada parâmetro, bem como para o indice clássico de seleção (SMITH, 1936).

Verifica-se pela análise de variância apresentadas nas Tabelas 25,27 e 29 que houveram algumas diferenças significativas ao nivel de significância de $5 \%$ de probabilidade entre as linhagens e cada um dos parâmetros avaliados MS, Utotal e IC, respectivamente. Quanto as herdabilidades de cada parâmetro, nota-se que para Utotal e IC foram obtidos os maiores valores de herdabilidade, sendo respectivamente $62 \%$ e $63 \%$, e mais baixa para MS $(50 \%)$.

Observa-se também pelo teste de Tukey que para os parâmetros Utotal e IC à semelhança dos resultados de herdabilidades, estas variáveis não diferem entre si, inclusive é lógico a ordem dos fungos. Neste caso, os resultados parecem indicar que a seleção seria realmente bastante efetiva na utilizaçầo de qualquer um desses dois parâmetros. Os dados obtidos confirmaram esta indicação, já que a linhagem $1 / 4$ selecionada como a mais promissora pelo parâmetro apresenta os mesmos resultados quando avaliados pelo indice IC, diferindo das outras linhagens mutantes e de seu parental, bem como das linhagens selvagens FP/21 e FP/69 e linhagem padrão FP/107, ao nivel de significância indicado. 
Tabela 25: Análise de variância da massa celular seca (MS) obtida pelas linhagens selvagens selecionadas FP/83, FP/69, e pelos mutantes de FP/83: $1 / 4,1 / 9,2 / 3,6 / 1$, e linhagem padrão $F P / 107$, nos ensaios cinéticos realizados.

\begin{tabular}{ccccc}
\hline $\begin{array}{c}\text { Causas da } \\
\text { variação }\end{array}$ & G.L. & S.Q & Valor F & Prob. > F \\
\hline Bloco & 2 & 4812.7741162 & 32.0247 & 0.00001 \\
Fungo & 7 & 8285.33444489 & 15.7519 & 0.00001 \\
Tempo de & 4 & & 91.8309 & 0.00001 \\
fermentaçäo (TF) & & 27601.2661710 & & \\
Fungo x TF & 28 & 4549.4264652 & 2.1623 & 0.00435 \\
Resíduo & 78 & 5861.0394149 & - & - \\
\hline Total & 119 & 1109.8406161 & - & - \\
\hline $\begin{array}{l}\text { Média geral }=54.762501 \\
h_{i}^{2}=0,496\end{array}$ & Coeficiente de Variação $=15.829 \%$ &
\end{tabular}

Tabela 26: Teste de Tukey para as médias da massa celular seca, obtida pelas linhagens selvagens selecionadas FP/83, FP/69, e pelos mutantes de FP/83: $1 / 4,1 / 9,2 / 3,6 / 1$, e linhagem padrão FP/107, nos ensaios cinéticos realizados.

\begin{tabular}{ccccccc}
\hline $\begin{array}{c}\text { Nümero de } \\
\text { Ordem }\end{array}$ & $\begin{array}{c}\text { Número de } \\
\text { Tratamento }\end{array}$ & Nome & $\begin{array}{c}\text { Número de } \\
\text { repetiçåo }\end{array}$ & Médias & originais & $5 \%$ \\
\hline 1 & 4 & FP/107 & 15 & 74.506667 & 74.506667 & $\mathrm{a}$ \\
2 & 7 & FP(2/3) & 15 & 56.820000 & 56.820000 & $\mathrm{~b}$ \\
3 & 3 & FP/83 & 15 & 55.926666 & 55.926666 & $\mathrm{~b}$ \\
4 & 6 & FP(1/9) & 15 & 53.186667 & 53.186667 & $\mathrm{bc}$ \\
5 & 8 & FP(6/1) & 15 & 53.180000 & 53.180000 & $\mathrm{bc}$ \\
6 & 1 & FP/21 & 15 & 51.626666 & 51.626666 & $\mathrm{bc}$ \\
7 & 5 & FP(1/4) & 15 & 47.680000 & 47.680000 & $\mathrm{bc}$ \\
8 & 2 & FP/69 & 15 & 45.173333 & 45.173333 & $\mathrm{c}$ \\
\hline
\end{tabular}

Médias seguidas por letras distintas diferem entre si ao nivel de significância indicado. 
Tabela 27: Análise de variância da Unidade enzimática total (Utotal) obtida pelas linhagens selvagens selecionadas FP/83, FP/69, e pelos mutantes de FP/83: $1 / 4,1 / 9,2 / 3,6 / 1$, e linhagem padrão $F P / 107$, nos ensaios cinéticos realizados.

\begin{tabular}{ccccc}
\hline $\begin{array}{c}\text { Causas da } \\
\text { variação }\end{array}$ & G.L. & S.Q & Valor F & Prob. > F \\
\hline Bloco & 2 & 70154.3900620 & 16.3804 & 0.00002 \\
Fungo & 7 & 387152.7874145 & 25.8276 & 0.00001 \\
Tempo de & 4 & 580633.2224536 & 67.7862 & 0.00001 \\
fermentaçäo (TF) & & & & \\
Fungo x TF & 28 & 213520.2411650 & 3.5611 & 0.00003 \\
Residuo & 78 & 167030.2441906 & - & - \\
\hline Total & 119 & 1418490.8852857 & - & - \\
\hline Média geral = 111.641335 & Coeficiente de Variação $=41.450 \%$ & \\
$h_{i}^{2}=0,623$ & & & &
\end{tabular}

Tabela 28: Teste de Tukey para médias do parâmetro Utotal, obtida pelas linhagens selvagens selecionadas FP/83, FP/69, e pelos mutantes de FP/83: $1 / 4,1 / 9,2 / 3,6 / 1$, e linhagem padrão $\mathrm{FP} / 107$, nos ensaios cinéticos realizados.

\begin{tabular}{ccccccc}
\hline $\begin{array}{c}\text { Número de } \\
\text { Ordem }\end{array}$ & $\begin{array}{c}\text { Número de } \\
\text { Tratamento }\end{array}$ & Nome & $\begin{array}{c}\text { Número de } \\
\text { repetiçảo }\end{array}$ & Médias & $\begin{array}{c}\text { Médias } \\
\text { originais }\end{array}$ & $5 \%$ \\
\hline 1 & 5 & $\mathrm{FP}(1 / 4)$ & 15 & 228.677334 & 228.677334 & $\mathrm{a}$ \\
2 & 6 & $\mathrm{FP}(1 / 9)$ & 15 & 143.816667 & 143.816667 & $\mathrm{~b}$ \\
3 & 3 & $\mathrm{FP} / 83$ & 15 & 135.216667 & 135.216667 & $\mathrm{~b}$ \\
4 & 7 & $\mathrm{FP}(2 / 3)$ & 15 & 116.714000 & 116.714000 & $\mathrm{~b}$ \\
5 & 8 & $\mathrm{FP}(6 / 1)$ & 15 & 110.429333 & 110.429333 & $\mathrm{bc}$ \\
6 & 1 & $\mathrm{FP} / 21$ & 15 & 60.616667 & 60.616667 & $\mathrm{~cd}$ \\
7 & 2 & $\mathrm{FP} / 69$ & 15 & 49.313333 & 49.313333 & $\mathrm{~d}$ \\
8 & 4 & $\mathrm{FP} / 107$ & 15 & 48.346667 & 48.346667 & $\mathrm{~d}$ \\
\hline
\end{tabular}

Médias seguidas por letras distintas diferem entre si ao nivel de significância indicado. 
Tabela 29: Análise de variância para o Índice clássico de Smith (IC), obtido pelas linhagens selvagens selecionadas FP/83, FP/69, e pelos mutantes de FP/83: $1 / 4,1 / 9,2 / 3,6 / 1$, e linhagem padrão FP/107, nos ensaios cinéticos realizados.

\begin{tabular}{ccrcc}
\hline $\begin{array}{c}\text { Causas da } \\
\text { variação }\end{array}$ & G.L. & S.Q & Valor $F$ & Prob. > F \\
\hline Bloco & 2 & 62152.7305817 & 14.5614 & 0.00004 \\
Fungo & 7 & 396693.2325690 & 26.5539 & 0.00001 \\
Tempo de & 4 & 525944.4398085 & 61.6100 & 0.00001 \\
fermentaçăo (TF). & & & & \\
Fungo x TF & 28 & 223244.1025144 & 3.7359 & 0.00002 \\
Residuo & 78 & 166465.0401981 & - & - \\
\hline Total & 119 & 1374499.5456718 & - & - \\
\hline Média geral $=99.155487$ & \multicolumn{4}{c}{ Coeficiente de Variação $=46.591 \%$} \\
$h_{i}{ }^{2}=0,630$ & & &
\end{tabular}

Tabela 30: Teste de Tukey para médias do parâmetro de seleção (IC) obtido pelas linhagens selvagens selecionadas FP/83, FP/69, e pelos mutantes de FP/83: $1 / 4,1 / 9,2 / 3,6 / 1$, e linhagem padrāo FP/107, nos ensaios cinéticos realizados.

\begin{tabular}{ccccccc}
\hline $\begin{array}{c}\text { Número de } \\
\text { Ordem }\end{array}$ & $\begin{array}{c}\text { Número de } \\
\text { Tratamento }\end{array}$ & Nome & $\begin{array}{c}\text { Número de } \\
\text { repetição }\end{array}$ & Médias & $\begin{array}{c}\text { Médias } \\
\text { originais }\end{array}$ & $5 \%$ \\
\hline 1 & 5 & $\mathrm{FP}(1 / 4)$ & 15 & 217.806298 & 217.806298 & $\mathrm{a}$ \\
2 & 6 & $\mathrm{FP}(1 / 9)$ & 15 & 131.690106 & 131.690106 & $\mathrm{~b}$ \\
3 & 3 & $\mathrm{FP} / 83$ & 15 & 122.465387 & 122.465387 & $\mathrm{~b}$ \\
4 & 7 & $\mathrm{FP}(2 / 3)$ & 15 & 103.759040 & 103.759040 & $\mathrm{~b}$ \\
5 & 8 & $\mathrm{FP}(6 / 1)$ & 15 & 98.304292 & 98.304292 & $\mathrm{bc}$ \\
6 & 1 & $\mathrm{FP} / 21$ & 15 & 48.845787 & 48.845787 & $\mathrm{~cd}$ \\
7 & 2 & $\mathrm{FP} / 69$ & 15 & 39.013813 & 39.013813 & $\mathrm{~d}$ \\
8 & 4 & $\mathrm{FP} / 107$ & 15 & 31.359147 & 31.359147 & $\mathrm{~d}$ \\
\hline
\end{tabular}

Médias seguidas por letras distintas diferem entre si ao nivel de significância indicado. 


\subsection{Teste comparativo entre a cinética do mutante mais promissor e seu parental}

Diante dos resultados encontrados no ensaio de cinética enzimática entre os mutantes mais promissores, foi realizada uma nova cinética para efeito comparativo com um maior número de pontos entre a linhagem selvagem selecionada de Trichoderma harzianum Rifai (FP/83) e seu mutante $1 / 4$, indicado como melhor.

Os resultados encontram-se listados na Tabela 31 , e 0 desempenho comparativo entre as duas linhagens pode ser observado na Figura 13. Verifica-se uma queda na produção entre a $144^{\text {a }}$ e a $154^{\text {a }}$ hora, retomada com valores crescentes até a 192 a , no momento da última amostragem. Sendo assim, não foi possivel verificar a fase final de produção enzimática para os fungos testados, porém, houve reprodutibilidade dos resultados, constatando mais uma vez a superioridade do mutante $1 / 4$, frente as atividades enzimáticas obtidas pelo seu parental (FP/83). A aplicação de um segundo ciclo de mutação-seleção pode promover resultados ainda melhores.

DIANOVA et al. (1970) selecionaram uma linhagem entre cerca de 1.000 mutagênicas: Etilenimina e U.V., bem como sua combinaçăo. Os autores verificaram que após o terceiro ciclo de mutaçãc-seleção, a atividade pectinolítica era de 3,5 vezes melhor que na linhagem original. Os autores sugerem que pelos resultados obtidos, apenas dois ciclos de mutação-seleção seriam suficientes. 
TABELA 31: Cinética comparativa entre a linhagem selvagem FP/83 e seu mutante $1 / 4$.

\begin{tabular}{|c|c|c|c|c|c|c|}
\hline Linhagens & $\begin{array}{c}\text { Tempo de } \\
\text { Fermentaçâa } \\
\text { (horas) }\end{array}$ & $\mathrm{U} / \mathrm{ml}$ & $\begin{array}{c}U \text { total } \\
(U \times 50 \mathrm{ml})\end{array}$ & $\begin{array}{c}\text { Uesp } \\
\text { (U total / g.m. } \\
\text { seca) }\end{array}$ & $\begin{array}{l}\text { Massa } \\
\text { Seca } \\
(\mathrm{mg})\end{array}$ & pH \\
\hline & 0 & - & 0 & - & 0 & 3.55 \\
\hline & 10 & 0.06 & 3.0 & 121.46 & 24.7 & 3.56 \\
\hline & 22 & 0.07 & 3.5 & 98.04 & 35.7 & 3.64 \\
\hline & 28 & 0.09 & 4.5 & 201.79 & 22.3 & 6.67 \\
\hline & 34 & 0.54 & 27.0 & 1.134 .45 & 23.8 & 3.68 \\
\hline & 46 & 1.54 & 77.25 & 2.399 .07 & 32.2 & 3.59 \\
\hline & 52 & 2.52 & 126.0 & 3.727 .81 & 33.8 & 3.62 \\
\hline & 58 & 1.66 & 82.78 & 2.019 .02 & 41.0 & 3.55 \\
\hline & 70 & 3.93 & 196.70 & 4.400 .45 & 44.7 & 3.81 \\
\hline \multirow[t]{15}{*}{$1 / 4$} & 76 & 4.42 & 220.91 & 3.980 .36 & 55.5 & 3.63 \\
\hline & 82 & 5.49 & 274.72 & 7.345 .45 & 37.4 & 3.65 \\
\hline & 95 & 6.62 & 330.91 & 6.644 .78 & 49.8 & 3.72 \\
\hline & 100 & 7.03 & 351.36 & - & 9.5 & 3.78 \\
\hline & 106 & 7.89 & 394.77 & 9.332 .62 & 42.3 & 3.76 \\
\hline & 119 & 7.72 & 385.98 & 8.520 .53 & 45.3 & 3.86 \\
\hline & 130 & 10.67 & 533.34 & 10.396 .49 & 51.3 & 3.89 \\
\hline & 142 & 13.16 & 658.23 & 13.112 .15 & 50.2 & 4.00 \\
\hline & 154 & 10.16 & 508.09 & 10.041 .30 & 50.6 & 3.90 \\
\hline & 166 & 11.71 & 585.32 & 10.759 .56 & 54.4 & 4.01 \\
\hline & 175 & 12.40 & 619.81 & 11.672 .50 & 53.1 & 4.30 \\
\hline & 197 & 14.71 & 735.55 & 13.521 .14 & 54.4 & 4.12 \\
\hline & 0 & - & 0 & - & - & 3.55 \\
\hline & 10 & 0.08 & 4.23 & 204.35 & 20.7 & 3.55 \\
\hline & 22 & 0.11 & 5.39 & 160.42 & 33.6 & 3.67 \\
\hline \multirow[t]{3}{*}{ FP/83 } & 28 & 0.12 & 6.20 & 268.40 & 23.1 & 3.67 \\
\hline & 34 & 0.18 & 8.83 & 331.95 & 26.6 & 3.68 \\
\hline & 46 & 0.62 & 30.82 & 883.09 & 34.9 & $\begin{array}{r}3.68 \\
\text { continua }\end{array}$ \\
\hline
\end{tabular}


continuação tabela 31

\begin{tabular}{|c|c|c|c|c|c|c|}
\hline Linhagens & $\begin{array}{c}\text { Tempo de } \\
\text { Fermentaçăo } \\
\text { (horas) }\end{array}$ & $\mathrm{U} / \mathrm{mi}^{\circ}$ & $\begin{array}{c}U \text { total } \\
(U \times 50 \mathrm{ml})\end{array}$ & $\begin{array}{c}\text { Uesp } \\
\text { (U total / g.m. } \\
\text { seca) }\end{array}$ & $\begin{array}{c}\text { Massa } \\
\text { Seca } \\
\text { (mg) }\end{array}$ & $\mathrm{pH}$ \\
\hline \multirow{15}{*}{$\begin{array}{c}\text { FP/83 } \\
\text { (parental) }\end{array}$} & 52 & 1.02 & 50.95 & 1.539 .27 & 33.1 & 3.59 \\
\hline & 58 & 1.43 & 71.61 & 1.850 .39 & 38.7 & 3.56 \\
\hline & 70 & 1.39 & 69.31 & 1.536 .81 & 45.1 & 3.79 \\
\hline & 76 & 2.38 & 118.89 & 2.421 .38 & 49.1 & 3.59 \\
\hline & 82 & 1.82 & 31.15 & 2.119 .77 & 43.0 & 3.57 \\
\hline & 95 & 2.70 & 134.98 & 2.705 .01 & 49.9 & 3.63 \\
\hline & 100 & 3.14 & 156.97 & 3.375 .70 & 46.5 & 3.63 \\
\hline & 106 & 3.03 & 151.48 & 3.749 .50 & 40.4 & 3.61 \\
\hline & 119 & 3.30 & 164.81 & 3.914 .73 & 42.1 & 3.71 \\
\hline & 130 & 4.21 & 210.39 & 4.302 .45 & 48.9 & 3.70 \\
\hline & 142 & 5.23 & 261.36 & 4.259 .06 & 50.8 & 3.85 \\
\hline & 154 & 3.89 & 194.74 & 3.553 .65 & 54.8 & 3.70 \\
\hline & 166 & 5.42 & 271.13 & 4.894 .04 & 55.4 & 3.88 \\
\hline & 175 & 6.19 & 309.52 & 5.458 .91 & 56.7 & 3.83 \\
\hline & 197 & 7.50 & 375.29 & 6.223 .71 & 60.3 & 4.19 \\
\hline
\end{tabular}




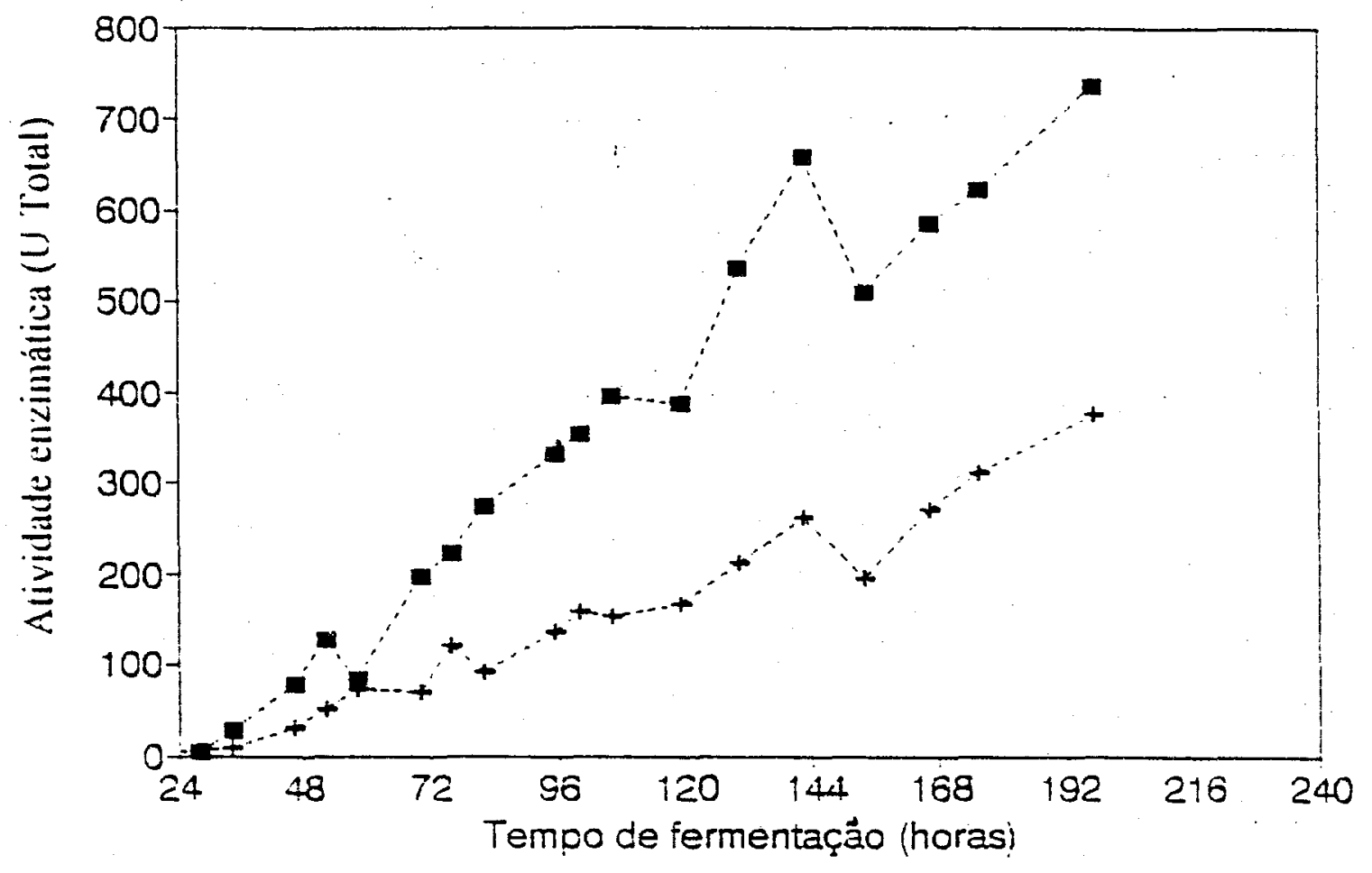

$$
\cdots-1 / 4 \quad \cdots+-\mathrm{fp} / 83
$$

Figura 13 - Cinética de crescimento com avaliação da atividade enzimática do mutante (1/4) e seu parental (FP/83).

\subsection{Preservação de linhagens}

A produção de substâncias industrialmente importantes pode depender de fatores relevantes ligados ao método de preservação empregado (CALAM, 1964; KIRSOP, 1986). Na literatura empregada especializada encontram-se descritos vários procedimentos aplicáveis a diferentes gêneros e espécies (SMITH \& ONIONS, 1983; GROUT, 1993). Entretanto, a literatura serve como orientação, mas 0 assunto muitas vezes ainda depende da experiência empirica (HILL, 1981).

A utilização de um único método de manutenção até se adquirir ampla experiência com determinados microrganismos é frequentemente 
desaconselhada (SILVA, 1990), sendo mais seguro o emprego de mais de uma forma de preservação. Assim sendo, por este, entre outros motivos, aplicou-se para as linhagens isoladas e selecionadas neste trabalho dois métodos de preservação: liofilização e criopreservação.

A Tabela 32 apresenta os resultados obtidos quanto a viabilidade celular (ufc/ml) das linhagens fúngicas selecionadas neste trabalho após submetidas à liofilização. Entre as sete linhagens avaliadas, verificou-se que a liofilização promoveu uma redução na viabilidade celular de duas a quatro vezes, mantendo-se na mesma ordem em termos de base logaritmica para algumas linhagens (P/42, FP/69 e FP/107).

Uma redução imediata devido ao congelamento e à secagem são normalmente esperados, pois tais procedimentos geram stress considerado suficiente para causar morte celular. Perdas desta ordem são, portanto, consideradas normais. De qualquer modo, um monitoramento posterior faz-se necessário, pois as condições de armazenamento, umidade residual e ausência de vácuo nas ampolas são fatores que podem contribuir para a mortalidade celular ao longo do tempo, a despeito do sucesso inicial do método (KIRSOP, 1984).

A linhagen FP/83 mostrou-se mais sensivel, pois cerca de 90 a $99 \%$ da viabilidade foram perdidos imediatamente após a liofilizaçăo, apresentando queda de $10^{8}$ para $10^{7}$, como observa-se na Tabela 32. Após 3 meses de estocagem em refrigerador, as contagens de viáveis mostram que 4 culturas mantiveram aproximadamente os valores obtidos após a liofilização . Apenas 2 culturas (FP/46 e FP/76) apresentaram perdas adicionais, as quais podem ser devidas aos fatores acima mencionados, como umidade residual, -ausência de vácuo, exposição à luz, além de sensibilidade particular da linhagem.

Uma maneira simples de se manter elevado o número de esporos viáveis seria concentrar ao máximo a suspensão inicial de protetor. Entretanto, a perda poderia continuar ocorrendo como resultado do congelamento e liofilização. 
Tabela 32: Viabilidade de culturas fúngicas (Ufc/ml) submetidos à liofilização (os valores representam médias de 3 repetiçōes).

\begin{tabular}{cccc}
\hline & & $\vdots$ & \multicolumn{3}{c}{$\begin{array}{c}\text { Periodo } \\
\text { Cultura }\end{array}$} & Antes da liofilização & Após a liofilização & 3 meses de estocagem \\
\hline FP/42 & $4,6 \times 10^{7}$ & $2,3 \times 10^{7}$ & $2,7 \times 10^{7}$ \\
FP/46 & $4,2 \times 10^{8}$ & $1,1 \times 10^{8}$ & $1,2 \times 10^{7}$ \\
FP/69 & $4,0 \times 10^{7}$ & $1,1 \times 10^{7}$ & $2,9 \times 10^{7}$ \\
FP/76 & $2,2 \times 10^{6}$ & $1,1 \times 10^{6}$ & $3,1 \times 10^{5}$ \\
FP/83 & $1,9 \times 10^{8}$ & $2,0 \times 10^{7}$ & $4,5 \times 10^{7}$ \\
FP/107 & $2,8 \times 10^{6}$ & $1,4 \times 10^{6}$ & $1,6 \times 10^{6}$ \\
\hline
\end{tabular}

Com relação às linhagens fúngicas produtoras de pectinases oriundas de coleções (Tabela 33), quando mantidos também por liofilização, apresentaram comportamento inicial mais satisfatório, já que todas as linhagens mantiveram a viabilidade celular da mesma ordem antes e imediatamente após o processo. Após dois anos de armazenamento, três linhagens apresentaram decréscimo, sendo Aspergillus oryzae (FP/107) a mais sensivel, permitindo, no entanto, a recuperaçāo de cerca de $10^{3} \mathrm{ufc} / \mathrm{ml}$.

Os isolados, quando mantidos por criopreservação em nitrogênio liquido (Tabela 34), mostraram, em sua maioria a manutenção da mesma ordem de viabilidade celular antes e depois do congelamento, apenas uma das linhagens mostrou-se mais sensivel (FP/42).

Tabela 33: Viabilidade de esporos fúngicos (Ufc/ml) submetidos à liofilização. Cada valor é média de três repetiçōes.

\begin{tabular}{lccc}
\hline \multicolumn{1}{c}{ Linhagens } & Antes do Estoque & $\begin{array}{c}\text { Período } \\
\text { Após o Estoque }\end{array}$ & 2 anos de estocagem \\
\hline $\begin{array}{l}\text { Aspergillus awamori } \\
\text { AWG 547 (FP/105) }\end{array}$ & $8,0 \times 10^{6}$. & $4,7 \times 10^{6}$ & $2,1 \times 10^{6}$ \\
$\begin{array}{l}\text { Aspergillus tamanii } \\
\text { (FP108) }\end{array}$ & $7,0 \times 10^{6}$ & $4,0 \times 10^{6}$ & $5,0 \times 10^{5}$ \\
Aspergillus niger- & $3,0 \times 10^{6}$ & $3,3 \times 10^{6}$ & $2,3 \times 10^{6}$ \\
$\begin{array}{l}\text { ATCC 1025 (FP/104) } \\
\text { Aspergillus oryzae } \\
\text { (FP/107) }\end{array}$ & $6,7 \times 10^{5}$ & $3,8 \times 10^{5}$ & $3,0 \times 10^{3}$ \\
$\begin{array}{l}\text { Aspergillus niger } \\
\text { NRRL 3122 (FP/103) }\end{array}$ & $5,3 \times 10^{6}$ & $4,5 \times 10^{6}$ & $1,7 \times 10^{5}$ \\
Aspergillus awamonii & $4,7 \times 10^{6}$ & $2,6 \times 10^{6}$ & $4,0 \times 10^{6}$ \\
NRRL3112 (FP/106) & & & \\
\hline
\end{tabular}


Após dois meses de armazenamento, sete das linhagens mantiveram a viabilidade próxima dos valores observados depois do congelamento, sendo a FP/76 e:a FP/107 as que apresentaram decréscimo adicional. Outras linhagens mostraram sensibilidade a um ou outro método imediatamente após a preservação ou após o estoque prolongado, não seguindo, no entanto, uma regra geral. Deve-se ter ainda em mente que, embora cada resultado seja a média de três repetições, os volumes avaliados são pequenos e o erro do método de contagem pode ser considerável, o que poderia acarretar imprecisōes nos valores obtidos. De qualquer modo, a recuperação pode ser considerada eficiente, pois altos valores foram mantidos pelos métodos empregados.

A linhagem FP/83, escolhida para a continuidade dos trabalhos, não se mostrou sensivel nem à liofilização, nem à criopreservação, mantendo altos os niveis de viabilidade nos periodos em que foi avaliada. Os mutantes obtidos foram igualmente submetidos aos dois métodos. O subcultivo foi empregado apenas nas fases iniciais de manutenção dos isolados, até se confirmar a eficiência dos outros métodos para as linhagens. As culturas continuarão a ser acompanhadas no que concerne à viabilidade celular, em intervalos mais longos entre cada avaliação, como parte da rotina do banco de microrganismos do AB-DQ / IPT.

Tabela 34: Viabilidade dos esporos das linhagens fúngicas isoladas neste trabalho, mantidas por criopreservaçāo em nitrogẻnio liquido (Ufc/ml).

\begin{tabular}{cccc}
\hline Linhagem & $\begin{array}{c}\text { Antes do } \\
\text { Congelamento }\end{array}$ & $\begin{array}{c}\text { Periodo } \\
\text { Após o } \\
\text { Congelamento }\end{array}$ & 2 meses \\
\hline FP/42 & $1,9 \times 10^{9}$ & $9,7 \times 10^{8}$ & $7,7 \times 10^{8}$ \\
FP/46 & $1,9 \times 10^{9}$ & - & $1,1 \times 10^{9}$ \\
FP/69 & $1,5 \times 10^{8}$ & $3,3 \times 10^{8}$ & $2,7 \times 10^{8}$ \\
FP/76 & $3,2 \times 10^{8}$ & $2,0 \times 10^{8}$ & $9,8 \times 10^{7}$ \\
FP/83 & $4,4 \times 10^{9}$ & $1,9 \times 10^{9}$ & $1,4 \times 10^{9}$ \\
FP/107 & $3,5 \times 10^{8}$ & $1,8 \times 10^{8}$ & $7,2 \times 10^{7}$ \\
\hline
\end{tabular}

A capacidade produtora de enzimas foi avaliada para as culturas isoladas neste trabalho, quando preservadas por liofilização e nitrogênio líquido. Foi empregado o indice de relação enzimática (IRE). Os resultados obtidos encontram-se nas Tabelas 35 e 36 . Tais resultados mostraram-se 
bastante variáveis, já que o método apresentou grandes limitaçöes, entre as quais a dificuldade de padronização dos inóculos empregados.

Tabela 35: Acompanhamento da produção de enzimas através da medida do $\mathrm{IRE}^{\star}$ das linhagens fúngicas liofilizadas.

\begin{tabular}{cccc}
\hline Método & antes & $\begin{array}{c}\text { Preservação- } \\
\text { liofilização } \\
\text { depois }\end{array}$ & $\begin{array}{c}\text { após } 2 \text { meses de } \\
\text { estoque }\end{array}$ \\
\hline FP/42 & 1.16 & 1.49 & 1.15 \\
FP/46 & 1.29 & 1.84 & 1.12 \\
FP/69 & 1.18 & 1.37 & 1.12 \\
FP/76 & 1.14 & 1.44 & 1.07 \\
FP/83 & 1.00 & - & 1.26 \\
FP/107 & 1.08 & 1.12 & 1.16 \\
\hline
\end{tabular}

OBS.: Estes resultados representam o valor médio da leitura de 3 placas.

*IRE - Índice de relação enzimática.

Tabela 36: Acompanhamento da produção de enzimas através da medida do IRE*, das linhagens fúngicas mantidas por criopreservação.

Método

Número de fungos

antes

1.16

1.29

1.18

1.14

1.00

1.08
Preservaçãonitrogênio líquido depois após 2 meses de estoque

1.13

1.12

1.17

1.11

1.32

1.14

* IRE - Indice de relação enzimática.

Embora alguns autores acreditem que o IRE não deva ser aplicado na comparaçāo entre espécies diferentes, restringindo o seu emprego para a comparaçāo entre variantes de uma mesma espécie (HANKIN \& ANAGNOSTAKIS,1975), pode-se imaginar que um grande número de repetições seja necessário, bem como uma padronização rígida do inóculo; do contrário, apenas diferenças bastante grandes poderão ser evidenciadas. 0 método como tal poderia ser empregado apenas no sentido de verificar se a linhagem perdeu ou não a capacidade produtora, ou seja, em termos apenas qualitativos. 


\section{CONCLUSÕES}

Os resultados obtidos no presiente trabalho permitiram concluir que:

- O uso da seleção de fungos em meio sólido através dos parâmetros IRE e ADE não se mostraram eficientes, levando a resultados contraditórios quanto à indicação daqueles mais promissores na produção de enzimas pectinolíticas. Assim, a necessidade do estabelecimento de métodos rotineiros mais rápidos e eficazes torna-se premente. Consideraçōes quanto às diferentes formas de interpretação que tais métodos podem sofrer devem ser feitas. Ademais, a elaboração dos meios empregados na seleção tanto em meio de cultivo sólido quanto em cultura submersa requer preocupação com a relação $\mathrm{C} / \mathrm{N}$ destes, para se evitar entre outros problemas, o efeito de repressão catabólica. É de extrema importância que tais deficiências sejam superadas.

- A seleção em cultura submersa, também apresentou outras limitaçōes, pois durante o "screening", devido ao tempo relativamente longo para as análises e ao grande número de isolados, tornava-se inviável a repetição dos testes fermentativos durante a primeira seleção; tanto para tomada de maior número de amostras, como para confirmação dos resultados obtidos, tendo sido realizado apenas uma medida no tempo de 72 horas de fermentação. Parece claro, no entanto, que o emprego deste método na seleção/comparação entre linhagens é melhor que em meio sólido pois elimina diferenças de inóculos; é menos subjetivo embora mais trabalhoso, pois se faz um controle (branco) para cada linhagem. Isto possibilita avaliaçōes e conclusōes mais precisas, valendo a pena o seu uso para "screening" em trabalhos de pesquisas, dependendo do número e importância das linhagens utilizadas. 
- A seleção em cultura submersa permitiu a obtenção da linhagem de Trichoderma harzianum Rifai: (FP/83), que mostrou-se promissora por apresentar valores de atividade enzimática superiores àqueles obtidos pelas outras linhagens selvagens, bem como pela linhagem de Aspergillus orysae (FP/107) utilizada como padrão. Foi possivel também verificar no presente trabalho uma alta variabilidade natural entre os isolados quanto à produção de enzimas pectinolíticas.

- A linhagem selecionada (FP/83) apresentou caracteristicas interessantes para estudos genéticos e de melhoramento para produção de enzimas pectinolíticas. A avaliação preliminar dessa linhagem evidenciou a presença de conídios verdes e uninucleados, facilidade na obtenção de mutantes morfológicos com luz ultravioleta, crescimento rápido em meio minimo e capacidade de produzir enzimas pepctinoliticas.

- A linhagem mutante $1 / 4$ obtida no presente trabalho demonstrou sua superioridade, apresentando valores de atividade enzimática cerca de duas vezes maior que àquelas apresentadas pelo seu parental (FP/83), indicando sucesso no uso do método clássico de mutação-seleção sobre esta linhagem.

- Os métodos de preservação aplicados para as linhagens fúngicas isoladas neste trabalho, bem como para àquelas já existentes no Banco de Linhagems do Laboratório de Microbiologia Industrial do AB-DQ / IPT, quais sejam, liofilização e criopreservação em nitrogênio liquido, mostraram-se em geral muito eficientes, mantendo a viabilidades destas a niveis bastante elevados.

- Através da análise realizada entre os parâmetros utilizados em meio sólido e líquido, foi possivel verificar uma baixa correlação entre os dois métodos de seleção. Tais análises também apontaram como mais adequado o método de seleção em cultura submersa, e neste os parâmetros indicados como melhores foram a Unidade total enzimática (Utotal) e o Índice clássico de SMITH (1936), combinando Utotal e Massa seca. 


\section{REFERÊNCIAS BIBLIOGRÁFICAS}

AGUILAR, G. \& HUITRON, C. Stimulation of the production of extracellular pectinolytic activities of Aspergillus $\mathrm{sp}$ by galacturonic acid and glicose addition. Enzyme Microbiol Technology, Stoneham, 9 (11): 690-6, Nov. 1987.

AMERICAN TYPE CULTURE COLLECTION. Media handbook. ATCC, Maryland, 1984, 98p.

ANGELOVA, M.; GRIGORON, I.; NIKOLOVA, N. mRNA stability responsible for polymethylgalacturonase biosyntesis of Aspergillus niger 26 strain. Doklady Akademiya Nauk, New York, 39 (8): 93-5, 1986.

AUNSTRUP, $K$. Production, isolation and economics of extracellular enzymes. In: WINGARD, L.; KATZIR, E.K.; GOLDSTEIN, L. ed. Applied Biochemistry and Bioengineering, New York, Academic Press, 1979. v.2, p. $27-69$.

AZEVEDO, J.L. Melhoramento genético de microrganismos e sua aplicação a hidrólise enzimática de biomassas. In: SEMINÁRIO DE HIDRÓLISE ENZIMÁTICA DE BIOMASSA, 2., Maringá, 1985. ANAIS Maringá, FUEM, 1985. p.93-106.

AZEVEDO, J.L. \& COSTA, S.O.P. Exercicios práticos de genética. Sāo Paulo, Nacional, Ed. Nacional, 1973. 288p. 
BAGALHI, E. Parameiose em Metarhizium anisopliae (Metsch.) Sorokin. Piracicaba, 1987. 123p. (Mestrado - Escola Superior de Agricultura "Luiz de Queiroz"/USP)

BAILEY, M.J. \& PESSA, E. Strain and process for production of polygalacturonase. Enzyme Microbiol Technology, Stoneham, 12 (4): 226-71, Apr. 1990.

BARFORD, H.C. Essay in applied microbiology. New York, John Wiley \& Sons, 1981.

BECKHORN, E.J.; LABBEE, M.D.; UNDERKOFLER, L.A. Prodution and use of microbial enzymes for food processing. Journal Agricultural Food Chemistry, Washington, 13 (1): 30, 1965.

BECKHORN, E.J. Production of industrial enzymes. Wallerstein Laboratories Communications, New York, 23: 201-11, 1960.

BERTOLINI, O.A. Isolamento e Biologia de novos fungos celulolíticos. Piracicaba, 1987. 63p. (Mestrado - Escola Superior de Agricultura "Luiz de Queiroz"/USP)

BISSET, J. A revision of the gams Trichoderma. Canadian Journal of Botany, Ottawa, 62: 924-31, 1984.

BOOTH, C. The genus Fusarium. Kew, Commonwealth Mycological Institute, 1971.

BOOTH, I.R. \& HIGGINS, C.F. eds. Regulation of gene expression: 25 years on. Cambridge, Cambridge University Press, 1986.

BUELL, C.B. \& WESTON, W. H. Application of the mineral oil conservation method to maintaining collections of fungus cultures. American Journal Botany, Lawrence, 34: 555-61, 1947. 
BULL, A.T.; ELLWOOD, D.C.; RATLEDGE, C. The changing scence in microbial technology. Society for General Microbiology Symposium, London, 29: 1-28, 1979.

CALL, H.P.; WALTER, J.; EMEIS, C.C. Maceration activity of an endopolyggalacturonase from Candida macedoniensis. Journal Food Biochemistry, 9 (4): 325-48, 1985.

CALAM, C.T. The selection, improvement and preservation of microrganisms Progress Industrial Microbiology, New York, 5: 1-54, 1964.

CARVALHO, C.M.V. Conidiação, obtenção de mutantes, heterocariose e atividade celulolítica na linhagem selvagem Trichoderma sp. Belo Horizonte, 1989. 141p. (Mestrado - Universidade Federal de Minas Gerais/UFMG).

CASTELLANI, A. Maintenance and cultivation of commom pathogenic fungi of man in sterile distilled water. Further researches. Joumal of Tropical Medicine and Hygiene, London, 70: 181-4, 1967.

DEMAIN, A.L. Theoretical and applied aspects of enzyme regulation and biosynthesis in microbial cells. Biotechnology and Bioengineering Symposium, New York, 3: 21-32, 1972.

- DEVEL, H. \& STUTZ, E. Pectic substances and pectic enymes. Advances in Enzymology, New York, 20: 341-82, 1958.

DIANOVA, O.P.; MARTAKOV, A.A.; BANKOZHITENKO, R.G.; NOVIKOVA, A.S. Selection of a producer of pectolytic enzymes by using mutagenic factor. Inedy Instituta Mikrobiologii i Virusologii, Akademiya Nauk Kazakhskoi SSR, Moscow, 15: 149-63, 1970. 
DURRANDS, P.K. \& COOPER, R.M. Development and analysis of pectic screening media for use in the detection of pectinase mutants. Applied Microbiology and Biotechnology, Berlim, 28: 463-7, 1988.

DUVE, C. de. A guided tour of the living Cell. New York, Scientific American Books, 1985.

ENDO, A. Productions of pectic enzymes. Hakko Kyokaishi, Tokyo, 20: 282-7, 1962.

FOGART, W.M. \& KELLY, C.T. Pectic enzymes. In: FOGART, W.M., ed. Microbiology Enzymes and Biotechnology. London, Applied Science publishers, 1983. Cap 3, p. 131-82.

FREEDMAN, R.B. \& HAWKINS, H.C. eds. The Enzymology of post translational modification of proteins. London, Academic Press, 1990. v.1.

FRIDURIK, J. Synthesis of a pectinolytic complex by Aspergillus niger 71, under conditions of submerged culture. Annales Universitatis Mariae CurieSklodowska, Sectio C., Lublin, 36: 37-50, 1983.

FRIESE, E.; LANCHTENBERGER, A.; MAREK, E. Improved manufacture of pectinolytic with inmobilized fungi. Applied Microbiology and Biotechnology, Berlim, 286: 144-7, 1987.

FUNGARO, M.H.P. Genética e melhoramento de Candida sp para a produção de coalho microbiano. Piracicaba, 1990. 119p. (Doutorado - Escola Superior de Agricultura "Luiz de Queiroz"/USP).

GACESA, P. \& HUBBLE, J. Enzyme Technology. New York; Open University Press, [198-]. 
GHILDYAL, N.P.; RAMAKRISHNA, M.; LOSANE, B.K; KARANTH, N.G. Gaseous concentration gradients in tray type solid state fermentors - Effect on yields and productivities. Bioprocess Engineering, 8: 677-72, 1992.

GODFREY, T. Enzymes for industry in the 90s. Industrial Biotechnology, Edinburg, 6 (1): 95, 1986.

GOLDMAN, G.H. Estudos genéticos e produção de celulases em Aspergillus niger. Piracicaba, 1988. 153p. (Mestrado - Escola Superior de Agricultura "Luiz de Queiroz/USP)

GOODENOUGH, P.W.; CLARK, D.C.; DURRANT, A.J. Structural analysis by circular dichroism of some enzymes involved in plant cell wall degradation. Febs Letters, Amsterdam, 282, (2): May 1991.

GRATZNER, H.G. Cell wall alterations associated with the hyperproduction of extracellular enzymes in Neurospara crassa. Journal of Bacteriology, Baltimore, 111: 443-6, 1972.

GREENE, H.C. \& FRED, E.B. Maintenance of vigorous mould stock cultures. Industrial Engineering Chemistry, New York, 26: 1297-9,1934

GYSLER, C. Isolation and structure of the pectin lyase D-encoding gene from Aspergillus niger. Gene, Amsterdam, 89 (1): 101-8, 1990.

HANKIN, L. \& ANAGNOSTAKIS, S.L. Solid media containing carboxymethylcellulose to detect $\mathrm{Cx}$ cellulose activity of microorganisms. Joumal of General Microbiology, London, 98 :105-15, 1977.

HANKIN, L. \& ANAGNOSTAKIS, S.L. The use of solid media for detection of enzyme production by fungi. Mycologia, New York, 67: 597-607, 1975.

HILL, L.R. Preservation of mirorganisms In: NORRIS, M.H.R., ed. Essays in Applied Microbiology. Chichester, John Wiley \& Sons, 1981. p. 1-30. 
HILL, L.R.; KOCUR, M.; MALIK, K.A. Culture and maintenance. In: HILL, L.R. \& KIRSOP, B.E. Living resources for biotechnology - Bacteria. Cambridge, Cambridge University Press, 1991. p. 62-78.

HOLLAND, I.B.; MACKMAN, N.; NICAUD, J.M. Secretion of proteins from bactéria. Biotechnology, 4: 427-431, 1986.

HUANG, $X$. Isolation and purification of polygalacturonas. Shipin Kexue, Osaka, 101: 15-8, 1988.

KAWAMORI, M.; MORIKAWA, Y.; SINSHA, Y. Preparation of mutants resistent to catabolic repression of Trichoderma reesei. Agricultural Biological Chemistry, Tokyo, $49: 2875-9,1985$.

KIRSOP, B. E. Culture collections - Their services to biotechnology. Trends in Biotechnology, New York, 1: 1-8,1983.

KIRSOP, B.E. Maintenance of microrganism a manual of laboratory methods. KIRSOP, B.E. \& SNELL, J.J., eds. London, Academic press, 1984.

KIRSOP, B.E. Service culture collection: Campinas, Fundação Tropical de Pesquisas e Tecnologia André Tosello, 1986.

KIRSOP, B.E. \& HENRY, J.E. Development of a miniaturised cryopreservation method for a wide range of yeasts, Cryoletters, Cambridge, 5: 191-200, 1984.

KLACIK, M.A. Enzymes in food processing. Chemical Engineering Progress, May 1988.

LARIOS, G.; GARCIA, J.M.; HOUTRON, C. Endo-polygalacturonase production from untreated lemon peel by Aspergillus sp $\mathrm{CH}-\mathrm{Y}-1043$. Biotechnology Letters, Kew, 11 (10): 729-34, 1989. 
LIMA, A. V.; AQUARONE, E.; BORZANI, W. Tecnologia das fermentações. São Paulo, Edgard Blucher, 1975. 285p. (Biotecnologia, 1).

LIN, M.T. \& DIANESE, J.C. A coconut agar medium for rapid detection of aflatoxin production by Aspergillus sp. Phytopathology, St. Paul 66: 14669, 1970.

LINEWEAVER, H. \& JANSEN, E.F. Pectic enzymes. Advances Enzymology, New York, 11: 267-95, 1951.

MAIORANO, A.E. Produção de pectinase por fermentação em estado sólido. São Paulo, 1990. 262p. (Doutorado - Escola Politécnica/USP).

MAIORANO, A.E.; PERES, C.S.; GUEDES, T.M.M. Estudo técnicoeconômico de avaliação de oportunidades em enzimologia. São Paulo, IPT, 1987.

MALDONADO, M.C. \& CALLIERI, D.A.S. Influence of enviromental conditions on the production of pectinesterase and polygalacturonase by Aspergillus niger. Applied Microbiology and Biotechnology, Berlin, 5 (3): 327-33, 1989.

MALIK, K.A. Preservation of microganisms by simple methods. In: WORKSHOP ON PRESERVATION OF MICRORGANISMS. Maryland,1988. Maryland, Univ. Maryland, 1988. p. 27-9.

MANACHINI, P.L.; PARINI, C.; FORTINA, M.G. Pectic enzymes from Aureobasidium pullulans LV 10. Enzyme Microbiology Technology, Stoneham, 10 (11): 682-5, Nov. 1988. 
MANDELS, M. Growth and cellulases production by Trichoderma. In: BAILEY, M.; et al. Symposium on the enzymatic hydrolysis of cellulose. Helsinki, The Finnish National Fund for Research and Development, 1975. p. 81109.

MARTIN, S.M. \& SKERMAN, B.D. World directory of micro-organisms. New York, Wiley Interscience, 1972.

MCKAY, A.M. A plate assay method for the detection of Polygalacturonase secretion. FEMS Microbiology Letters, Amsterdam, 56 (3): 335-58, 1988.

MCLLAVAINE, T.C. A buffer solution for colorimetric comparison. The Journal of Biological Chemistry, Baltimore, 49,(1): 183, Nov. 1921.

MONOSCO, I.L. Produção de enzimas extracelulares em haplóides, heterocários e diplóides de Aspergillus nidulans. Campinas, 1987. 93p. (Mestrado - Universidade de Campinas /UNICAMP).

MONTENECOURT, B.S. \& EVELEIGH, D.E. Preparation of mutants of Trichoderma with enhanced cellulase production. Applied and Environmental Microbiology, Baltimore, 34: 777-82, 1977.

MURAYAMA, T. \& ISHIKAWA, T. Mutation in Neurospora crassa affecting some of the extracellular enzymes and several growth caracteristics. Journal of Bacteriology, Baltimore, 115: 796-804, 1973.

NARAHARA, H.; KOYAMA, Y.; YOSHIDA, T.; PICHANGKURA, S.; UEDA, R.; TAGUCHI, $\mathrm{H}$. Gowth and enzyme production in a solid-state culture of Aspergillus orysae. Journal Fermentation Technology, Tokyo, 60 (4): $311-19,1982$.

PACCOLA-MEIRELLES, L.D.; VALARINI, M.J.; AZEVEDO, J.L.; ALFENAS, A.C. Manual de Técnicas eletroforéticas em microrganismos. Piracicaba, FEALQ, 1988. 54p. 
PARK, Y.K. Influência do nitrogênio orgânico sobre a produção de alfaamilase fúngica. Campinas: ITAL, 1970. p. 191-194. (Coletânea do ITAL, 3).

PARK, Y.K., FUJUKI, E., LIMA, D.C. Produção de enzimas pectinoliticas por fungos. Revista Brasileira de Tecnologia, v.3, p. 197-203, 1972.

PARK, Y.K. \& PAPINI, R.S. Produção de enzimas. In: LIMA, V.A., AQUARONE, $E$, BORZANI, W. (coord.). Tecnologia das fermentações. 3. ed. São Paulo: 1986. p. 182-211.

PARK, Y.K. \& PAPINI, R.S. Produção de enzimas industriais e sua aplicação no processamento de alimentos. Boletim do Centro Tropical de Pesquisas e Tecnologia de Alimentos, n. 16, dez. 1968.

PEREIRA, J.O. Ocorrência do ciclo parassexual em uma espécie do gênero Aspergillus. Piracicaba, 1978. 108p. (Mestrado - Escola Superior de Agricultura "Luiz de Queiroz"/USP).

PERKINS,D.D. Preservation of Neurospora stock cultures with anhydrous silica gel. Canadian Joumal Microbiology, Ottawa, 8: 591-4, 1962.

PETRUCCIOLI, M., MONTELEONE, E., FREDERICI, F. Optimization of polygalacturonase production by Aureobasidium pullulans on orange pull waste. Yeast, v.5, p. 157-62, Apr. 1989.

PITOMBO,R.N.M. A liofilizaçāo como técnica de conservação de material de pesquisa. Ciência Cultura (São Paulo), 41: 427-31,1989.

PONTECORVO, G.; ROPER, J.A.; HEMMONS, C.M.; MCDONALD, K.D.; BUFTON, A.W.J. The genetics of Aspergillus midulans. Advances Genetics. New York, 5: 141-238, 1953. 
RIFAI, M.A. A revision of the gens Trichoderma. Mycological Papers, v.116, p.1-56, jan. 1969.

RODRIGUES, E.C. Caracterização citogenética e bioquímica do fungo celulolítico Humicola sp. Piracicaba, 1987. 152p. (Mestrado - Escola Superior de Agricultura "Luiz de Queiroz"/USP).

ROMBOUTS, F.M. \& PILNIK, W. Research on pectin depolymerases in the sixties - A literature review. Critical Review Food Science and Technology, Boca Raton, 3: 1-26, Apr. 1972.

ROMBOUTS, F.M., PILNIK, W. Microbial enzimes and bioconversions. In: ROSE, A.H, ed. Economic microbiology, London, Academic Press, 1980. v. 5 , p. $227-83$.

ROMBOUTS, F.M., PILNIK, W. Pectinases and other cell-wall degrading enzymes of industrial importance. Symbiosis, Cambridge, 2: 79-90, 1986.

ROUMAS, N.E. Produção de celulases e fusão de protoplastos em Humícola sp. Piracicaba, 1988. 168p. (Doutorado - Escola Superior de Agricultura "Luiz de Queiroz"/USP).

SCHIMENTI, J.; GARRETT, T.; MONTENECOURT, B.S. Selection of hypercellulolytic mutant of Trichoderm reesei based on resistence to nystatin. Mycologia, Lancaster, v.75, p.876-880. 1983.

SIÉSSERE, V. Otimização das condições de cultivo para produção e parcial caracterização das enzimas pectinoliticas de Penicillium frequentans. Piracicaba, 1991. 118p. (Mestrado - Escola Superior de Agricultura "Luiz de Queiroz"/USP).

SILVA, L.F. Comparação de métodos de preservação de leveduras de interesse industrial. São Paulo,1990. 152p. (Mestrado - Instituto de Ciências Biomédicas/USP). 
SILVA,L.F.; KAMIYA, N.F.; OLIVEIRA, M.S.; ALTERTHUM, F. Comparison of preservation methods applied to yeast used for ethanol production in Brazil. Revista Microbiologia. São Paulo, 23 (3): 177-182, 1992.

SMITH,D. \& ONIONS, A.H.S. The preservation and maintenance of living fungi. Commonwealth Mycological Institute, Surrey, Eng., 51 p, 1983.

SMITH, J.E. \& BERRY, D. eds. The filamentons fungi. London: Edward Arnold Ltd, 1975.

SREENATH, H.K.; KOGEL, F.; RADOLA, B.J. Macerating properties of a commercial pectinase on carrot and celery. Journal Fermentation Technology, Tokyo, 64 (1): 37-44, 1986.

STANBURY, P.F., WHITAKER, A. Principles of fermentation technology. New York: Pergamon Press, 1984.

STANDARD SPECIFICATIONS AND OPERATIONS INSTRUCTIONS (ASTM) for glass capillary kinematic wiscometers, D-446-70. Philadelphia, 1970, v.23, p. 249.

STRZELCZYK, E.; DAHM, H.; KOWALSKY, S. The influence of $\mathrm{pH}$ and temperature on cellulolytic and pectolytic activity of Cylindrocarpon destructans (Zins) Scholt. Journal Phytopatology, Berlin, 120 (2): 97-103, 1987.

THOMPSON, J. P. Survival of Azotobacteriaceae desiccated over silica gel. Applied Microbiology and Biotechnology, Berlin, 3: 185-96, 1987.

TOYAMA, H.; YAMAGUCHI, K.; SHINMYO, A. Protoplast fusion of Trichoderma reesei, using immature conidia. Applied and Environmental Microbiology, Baltimore, 47: 363-8, 1984. 
TSUYUM, S.; ISHII, S.; NAKAMURA, M. Plate assay for differentiation of different pectinases. Agriculture Biological Chemistry, 53 (9): 2509-11, 1989.

VALADARES, M.C.C Genética e produção de exoenzimas em linhagens de Metharizium anisopliae var. anisopliae (Metsh.) Sorokin. Piracicaba,1989. 160p. (Mestrado - Escola Superior de Agricultura "Luiz de Queiroz"/USP).

VEGA, M. E. Aspectos da parameiose na fusão de protoplastos em Metharhizium anisopliae (Metsch.) Sorokin. Piracicaba,1990. 95p. (Mestrado - Escola Superior de Agricultura "Luiz de Queiroz"/USP).

VICENTE, V. A. Isolamento e seleção de fungos lignocelulolíticos. Piracicaba, 1989. 172p. (Mestrado em Agronomia) - Escola Superior de Agricultura "Luiz de Queiroz"/USP).

VITOLO, M. Tópicos de enzimologia industrial. São Paulo, Litografia Corsário, 1981. 65p.

WALLERSTEIN, L. U. S. Pat. 995820 and 995823-6, 1911.

WISEMAN, A., ed. Handbook of enzyme biotecnology. 2.ed. Chichester, Ellis Horwood, 1985.

ZALDIVAR, M.; STEINER., J; MUSALEM, M. Aislamiento de um mutante de Trichoderma pseudokoningi hiperprodutor de celulases. Microbiologia, Santiago, 3: 33-44, 1987. 